\title{
Images of Uncertainty:
}

\section{War, Cinema and Visual Culture}

By

Michael Freethy, BA (Hons.)

A thesis submitted to the Faculty of

Graduate Studies and Research in partial fulfillment

of the requirements for the degree of

Masters of Arts

in Film Studies

Carleton University

Ottawa, Ontario

August 2008

(C) 2008, Michael Freethy 


$\begin{array}{ll}\begin{array}{l}\text { Library and } \\ \text { Archives Canada }\end{array} & \begin{array}{l}\text { Bibliothèque et } \\ \text { Archives Canada }\end{array} \\ \begin{array}{l}\text { Published Heritage } \\ \text { Branch }\end{array} & \begin{array}{l}\text { Direction du } \\ \text { Patrimoine de l'édition }\end{array} \\ \begin{array}{l}\text { 395 Wellington Street } \\ \text { Ottawa ON K1A 0N4 } \\ \text { Canada }\end{array} & \begin{array}{l}\text { O95, rue Wellington } \\ \text { Ottawa ON K1A 0N4 } \\ \text { Canada }\end{array}\end{array}$

Your file Votre référence ISBN: 978-0-494-43458-1

Our file Notre référence

ISBN: 978-0-494-43458-1

NOTICE:

The author has granted a nonexclusive license allowing Library and Archives Canada to reproduce, publish, archive, preserve, conserve, communicate to the public by telecommunication or on the Internet, loan, distribute and sell theses worldwide, for commercial or noncommercial purposes, in microform, paper, electronic and/or any other formats.

The author retains copyright ownership and moral rights in this thesis. Neither the thesis nor substantial extracts from it may be printed or otherwise reproduced without the author's permission.
AVIS:

L'auteur a accordé une licence non exclusive permettant à la Bibliothèque et Archives Canada de reproduire, publier, archiver, sauvegarder, conserver, transmettre au public par télécommunication ou par l'Internet, prêter, distribuer et vendre des thèses partout dans le monde, à des fins commerciales ou autres, sur support microforme, papier, électronique et/ou autres formats.

L'auteur conserve la propriété du droit d'auteur et des droits moraux qui protège cette thèse. $\mathrm{Ni}$ la thèse ni des extraits substantiels de celle-ci ne doivent être imprimés ou autrement reproduits sans son autorisation.
In compliance with the Canadian

Privacy Act some supporting forms may have been removed from this thesis.

While these forms may be included in the document page count, their removal does not represent any loss of content from the thesis.
Conformément à la loi canadienne sur la protection de la vie privée, quelques formulaires secondaires ont été enlevés de cette thèse.

Bien que ces formulaires aient inclus dans la pagination, il n'y aura aucun contenu manquant.

\section{Canada}




\begin{abstract}
This thesis swims through the "fog of war" projected on the multiple screens of digital media, more specifically, through analyses of contemporary war films. With growing public suspicions, doubts and uncertainties associated with foreign policies of the Bush-led "War on Terror," (or more specifically, the war in Iraq) the war film genre has perpetuated these concerns through a variety of narrative and aesthetic strategies. New ways of visualizing and representing war through digital media are being challenged by these films on both narrative and formal levels, forming what I define as a new 'logistics of perception.' The soldier's 'on-the-ground' experience and viewers' mediated experience of contemporary war is being blurred by the weakening distinctions between professional, consumer, and military digital technologies. The films in this thesis are largely informed by the aesthetics of digital video found in a plethora of new media (MiniDV, YouTube, night-vision, cell phone cameras), but the aesthetics of these seemingly new images can be traced back to early war photography of the mid-nineteenth century. The contemporary war film reflects current problems with representing and making sense of war in a digital era, but also return us squarely to issues that have plagued the representation of war since the first snapshots.
\end{abstract}




\section{ACKNOWLEDGEMENTS}

I wish to thank first and foremost my thesis supervisor Marc Furstenau for sharing his wealth of knowledge, assistance, and great enthusiasm throughout the development of this project. Without his first-rate guidance, infallible advice, and support throughout this year, this paper would not be what it is today! I would also like to thank Prof. Jim Leach of Brock University and the staff and faculty of Carleton's Film department for all their help, ideas, and numerous letters of reference throughout these last two years, especially José Sanchez, André Loiselle, Mitsuyo Wada-Marciano, Charles O'Brien, Mark Langer, and of course, Diane Berezowski. Your joyful presence and marvelous support for students is inspirational. I don't know how I'll ever pay you back for all the gummie worms, cherry blasters, and chocolate I've taken from you.

My peers also deserve credit for many of the ideas and thoughts that have worked their way into this thesis. RJ Tougas - his sincere interest and brilliant suggestions for my work have been truly appreciated. It is a privilege to have met you. Erin Jennings her friendship and likeness for things that "blur the boundaries" is inspirational, on both a personal, and intellectual level of course. I would also like to thank my parents (Reg and Carole Freethy), the Millers (Keith and Cathy) and my lovely sisters (Grace, Michele, Maria, and Tamara) for their support throughout these last six crazy years of university. Last, but certainly not least, I owe an obscene amount of gratitude and appreciation to my best friend and "light, of my life," Leslie Miller, soon to be Mrs. Freethy. Her love, support, and respect throughout these last two years will be forever treasured. I cannot wait to spend the rest of our life together! 


\section{TABLE OF CONTENTS}

1. INTRODUCTION: 1

The "Fog of War" and Digital Visual Culture

2. CHAPTER ONE:

From Fenton to Bush: The Development of Photographic

Realism

I: Tracing Realism in Roger Fenton's Valley of the

15

Shadow of Death

II: Changing Notions of War Realism and Robert Capa

21

III: Raising Flags on Mount Suribachi and Ground Zero

28

- Flags of Our Fathers

3. CHAPTER TWO:

41

Digital Ways of Seeing

I: David Versus Goliath: Trauma, Truth and In the Valley 44 of Elah

II: The "Automation of Sight" and The War Tapes 54

III: Seeing Through the "I's" of the Soldier - Occupation: 63

Dreamland

\section{CHAPTER THREE:}

Advocating the Localized Perspective in War Images

I: Of Docu-Drama and Dialectics - The Road to Guantánamo

76

II: "Collaborative Histories" and A Nation Divided - Iraq

87 in Fragments

III: Insurgency Agency - The Blood of My Brother

95

4. CONCLUSION:

108

Seeing Through the Fog and the Screens of War-Redacted

5. BIBLIOGRAPHY 


\section{INTRODUCTION}

\section{The "Fog of War" and Digital Visual Culture}

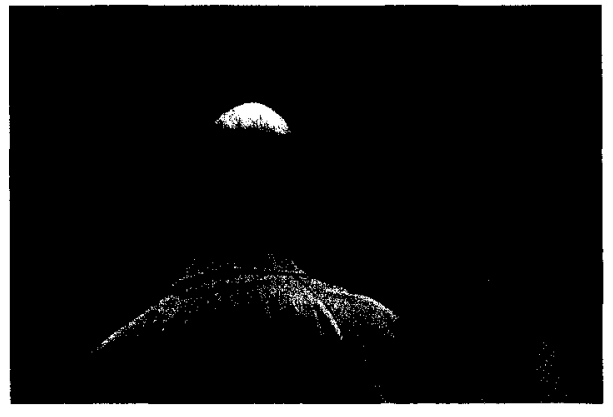

Figure 1.1 The Fog of War (Errol Morris, 2003)

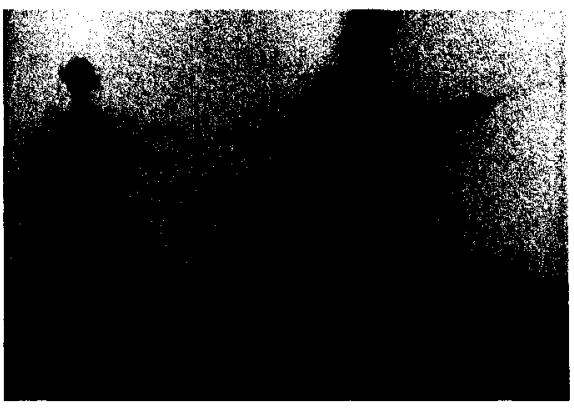

Figure 1.2 The Fog of War

A coarse voice accompanies an image of an older man walking with his back facing the camera towards a blurred background (Figure 1.1 and Figure 1.2). His words are delivered with exhaustion and conviction, pausing momentarily between each sentence: “We all make mistakes. We know we make mistakes. I don't know any military commander who is honest, who would say he has not made a mistake." The voice belongs to former US Secretary of Defense, Robert Strange McNamara, who is the subject of Errol Morris's film, The Fog of War: Eleven Lessons from the Life of Robert S. McNamara (2003). The film is about McNamara's insights into his term in office throughout the Cold War and, notably, the Vietnam War. He explains,

There's a wonderful phrase - "the fog of war." What "the fog of war" means is war is so complex it's beyond the ability of the human mind to comprehend all of the variables. Our judgment, our understanding, are not adequate. And we kill people unnecessarily.

His illuminating description of the "fog of war" presents the viewer with a dual metaphor: one reflecting his moral conundrum as the American Secretary of 
Defense during the Kennedy and Johnson administrations, and the other reflecting how war tends to escape human understanding.

The "fog of war" evokes the complexity of modern warfare in its various guises: socially, politically, economically, culturally, and morally. The complicated moral implications involved in war discussed in the film are reinforced through the film's formal properties, and stylistic and aesthetic attributes. Morris creates a cinematic web by utilizing various media (such as archival war footage, network news reports, press conferences) to accompany McNamara's interviews to create a formally complex documentary. In this sense, the various forms used in Morris's film reflect McNamara's testimonies that explain his complex role in government. Morris's film conjures up the question: how does one begin to talk about and make sense of war? This thesis will examine how the "fog of war" is represented in contemporary cinema, specifically, in the war film since September $11^{\text {th }}, 2001 .^{1}$ I will investigate how different films belonging to this genre confront the representation of war, and how the uncertainties of the war in Iraq and its mediated representation are echoed in their formal appearances.

This thesis is not specifically concerned with the political implications of the war in Iraq, but rather how this war is represented in cinema, in both fiction and nonfiction films, and within the broader visual culture. The films and other media analyzed in this thesis exhibit a heightened sense of dismay and anxiety about the United States'

\footnotetext{
${ }^{1}$ The "contemporary war film" will be used through this argument when referring to both fictional and documentary war films that will be discussed through this project. This amalgamation of terms in this phrase will be made clearer in subsequent chapters.
} 
current efforts in the Middle East. Suspicions about the role that US-led forces play in Iraq and Afghanistan arise out of these texts through a myriad of aesthetic and technical strategies (editing, shooting style). This uncertainty is a direct manifestation and reflection of increasing societal concerns over the justifications for the war in the Middle East. Iraq's "weapons of mass destruction" have never been found, despite the persuasive PowerPoint evidence that Colin Powell provided to the UN Security Council on February 5, 2003. Citizen support for the Iraq invasion was quite high initially following such persuasive performances, but have continued to plummet since 2003 and anti-war demonstrations throughout the US and around the world continue five years since the invasion had begun. The films and other media texts in this thesis are concerned with the over-abundance of conflicting information circulating in the media and reflect the growing anxieties, confusion, and dismay people of the world have for this war.

Canadian historian Paul Rutherford proposes in his book, Weapons of Mass Persuasion: Marketing the War Against Iraq, that Western news coverage has generated an overwhelming amount of competing observations and perceptions of the war in Iraq. ${ }^{2}$ He raises the question: "How could anyone make sense out of such a profusion of information, analysis, speculation, rumour, and contradiction?"3 This convoluted form of war coverage is exemplified in an interview with documentary filmmaker, Michael Moore on Fox News'The O'Reilly Factor, hosted by Bill

\footnotetext{
${ }^{2}$ It should be duly noted that I will be using "Western" as a shorthand for referring to the United States, Canada, and western European nations.

${ }^{3}$ Paul Rutherford, Weapons of Mass Persuasion: Marketing the War Against Iraq, (Toronto: University of Toronto Press, 2004): 111.
} 
O'Reilly. ${ }^{4}$ After debating the Bush Administration's motives behind the war, O'Reilly explains at the end of their exchange: "It just shows you that I see the world my way, you see the world your way. ...And then we let the audience that is watching here, to decide who is right and who is wrong." This 'democratic' and adversarial structure of the segment is quickly undermined when O'Reilly concludes his program by stating: "No matter how much evidence that we [Fox News] produce..., you will never, ever get a 'Bush-hater' to concede lies were not told. That ladies and gentlemen is blind ideology, and blind ideology is never good on either side." O'Reilly's actual refusal to allow viewers to come to their own conclusions and form their own opinions about what had been debated reinforces Rutherford's ideas about the difficulties of making sense out of the often contradictory accounts presented in the news media. Despite as the claim that it has been "the most media-covered war in recent times," the meaning of the war in Iraq has become more complicated through the abundance of media speculation and contradiction manufactured for viewers at home. ${ }^{5}$

This abundance of information is also due in part to the various digital technologies that soldiers and civilians are utilizing to circulate alternative perspectives on the war, different from the mainstream media. More and more "non-professional" and "amateur" photographers and journalists are reporting and documenting the war from the front lines through digital camcorders, internet blogs, camera phone imagery, viral video sites like YouTube, independent documentaries, and other digital media

\footnotetext{
${ }^{4}$ The full Michael Moore interview on The O'Reilly Factor can be accessed on YouTube in two parts at http://www.youtube.com/watch?v=trOdCU6aZOg and http://www.youtube.com/watch?v=fLHI0b43xa4\&feature=related.
} 
platforms. The films in this thesis include these discursive new media practices in the construction of their war narratives. However, the idea of less professional modes of journalistic reporting has not toppled or dismantled the authority of the mainstream, but has enabled people, with access to various electronic media, to have a more egalitarian and interactive relationship with the wealth of personal opinions and attitudes circulated within global media. Many of these films adopt or simulate the "look" of digital media technologies for principal photography and/or include them within their narrative diegesis. Some of these films also align the "look" of the camera with the optical perspectives of military weaponry and visual technology, combining the camera's gaze with the "look" of military vision technology.

Nicholas Mirzoeff, a British citizen and culture critic, notes his experience of watching the live-fed image of the "shock and awe" bombing campaign on television in Long Island in his book, Watching Babylon: The War in Iraq and Global Visual Culture, and found that it represented "the peculiarity of American visual subjectivity." Mirzoeff's comment may have something to do with the highly technological representation of the bombing from the city's outer limits. American networks' coverage of the war (like CNN's and Fox News') prominently featured night-vision imagery of smoke rising above the earth as bombs devastated city structures, and other images that captured the sheer spectacle of explosions that lit the nighttime sky - avoiding any visual depiction of the civilians severely injured or killed

\footnotetext{
${ }^{5}$ Howard Tumber and Jerry Palmer, Media at War: The Iraq Crisis, (Thousand Oaks: Sage Publications, 2004): 1 .

${ }^{6}$ Nicholas Mirzoeff, Watching Babylon: The War in Iraq and Global Visual Culture, (New York: Routledge, 2005): 5.
} 
by attacks. J. David Slocum quotes Mark Lacy's suggestion that this televisual aesthetic of war is also reproduced in film: "“[C]inema has been concerned with normalizing the idea of war as the natural order of things,'...with developing 'distancing techniques [that] are deployed to create moral indifference to suffering".? The visual spectacle of the bombing campaign suppressed human suffering and death inflicted on the people of Baghdad.

This display of warfare seen on television and in the cinema can be traced back to the days of early war photography. Hence, the films in this thesis will be placed within a broader socio-historical and discursive context that will include considerations of other visual media, notably photography. Chapter One will discuss some of the key arguments and figures in the history of war photography and the development of photographic realism. Susan D. Moeller suggests that photography enabled a new kind of way to experience and bear witness to war: "[T]he camera has brought the exotic and dangerous near; it satisfies a lust for seeing the action, with the bonus that the viewer at home is never in any danger". ${ }^{8}$ This idea of one being able to experience war vicariously through the photographic image will be central to my criticisms of the photographic representation of the war experience. This section will demonstrate how realism was achieved and developed in early war photography of the Crimean War to WWII to represent a preferred style of "photographic truth." Scholars working on

\footnotetext{
7 J. David Slocum, "General Introduction: Seeing Through American War Cinema" in Hollywood and War: The Film Reader, ed. J. David Slocum, (New York: Routledge, 2006): 19.

${ }^{8}$ Susan D. Moeller, Shooting War: Photography and the American Experience of Combat, (New York: Basic Books, 1989): 3.
} 
contemporary war films often fail to recognize the importance of early war photography and its impact on the ways in which these films adopt a realist and often 'amateur' photographic aesthetic. Most tend to discuss combat films and documentaries of WWII as a central point of reference when analyzing the formal characteristics of many contemporary war films. I do not dispute this fact, but I think that one can go even further, and notice interesting parallels and connections of these films to early photography. The films discussed in this chapter include Saving Private Ryan (Steven Spielberg, 1998), and Flags of Our Fathers (Clint Eastwood, 2006).

Chapter Two will expand on these issues of photographic representation discussed in Chapter One and demonstrate how digital technologies are utilizing a realist photographic aesthetic. Contemporary war films often recreate or simulate the soldiers' gaze by abiding by the conventions of war photography. Some of the films described in this chapter feature and simulate imagery associated with military optical equipment such as night-vision goggles and cameras, creating a highly subjective camera gaze that combines the "look" of the camera with that of the social actor or character featured on-screen. Furthermore, digital devices such as camera phones (a combination of still image, cell phone, and digital video technology) and MiniDV (a $6.35 \mathrm{~mm}$ wide digital tape format) cameras are now being used by American soldiers and independent filmmakers to reproduce a more immediate and 'real' war experience. The functions of these new media technologies will be analyzed in In the Valley of Elah (Paul Haggis, 2007), The War Tapes (Deborah Scranton, 2006), and Occupation: Dreamland (Ian Olds and Garrett Scott, 2005). The function and utilization of various digital media within these films enable viewers to witness new and different ways for 
soldiers to tell war stories through new media technology, again, trying to make sense of the war in Iraq.

Chapter Three will discuss other Iraq war films that dispense with the testimony of American soldiers, and focus instead on the Iraqi civilian experience by adopting a highly subjective camera gaze. Martin Bell, a former British war correspondent turned Member of Parliament, complains that "the recent coverage of the Iraq war [represents] warfare by showing the shooting and not the victims". ${ }^{9}$ Some American and/or British filmmakers have produced films that advocate and facilitate the stories of the largely overlooked civilian population of Iraq. The films primarily discussed in this chapter include The Road to Guantánamo (Michael Winterbottom and Mat Whitecross, 2006), Iraq in Fragments (James Longley, 2006), and The Blood of My Brother (Andrew Berends, 2005).

The concluding chapter will summarize these issues discussed in the last three chapters through an analysis of Redacted (Brian De Palma, 2007). Redacted is a film that acknowledges the spectatorial maneuvers that people make when navigating through various media to make sense of the war in Iraq. De Palma oscillates between various new media modes of address including a digital video diary shot by an American soldier, surveillance imagery, a French documentary, and video blogs from both YouTube-style and pro-Jihad websites. The film's mixed media arrangement of images constructs a disjointed and fragmented account of events, inspired by a real incident that involved the rape, torture, and subsequent murder of a 14 year-old Iraqi girl and her family by

\footnotetext{
${ }^{9}$ Evans Chan, "War and Images" in Film International 5 (2003): 35.
} 
American soldiers. De Palma's refusal to stick to one fixed mode of address causes viewers to become more active during the reception of the film. This last chapter will bring this argument full circle to the epistemological and ontological problems associated with making sense of war in the digital media era addressed in prior chapters.

The contemporary war film has created new ways for viewers to interact with the barrage of media on the war in Iraq, a new "logistics of perception." This term was coined by Paul Virilio, who insists that:

[B]y upsetting geocentric cosmogony, this reverberation of the human look called perceptual faith itself into question, and 'remote perception' anticipated the grave philosophical problems that have recently been posed by 'electrooptical television,' as a preliminary to a new science of 'visionics' concerned with the automated interpretation of reality. ${ }^{10}$

The films in this thesis appear to be similarly concerned with what faith we can still have in images of our perceptual multimedia environment. It is not just viewers back at home who are being held hostage to the "automated interpretation of reality" perpetuated by the media, but also soldiers on the ground. Virilio also explains in the book that, "[f]or men at war, the function of the weapon is the function of the eye." most importantly, the war in Iraq, is increasingly managed through the use of visual technologies, further eliminating the conventional notion of the physical and 'unmediated' battlefield. Wired magazine war correspondent, Joshua Davis, reports on a personal experience in Iraq that involved rapid communications of the American military: "What we saw in [Iraq] was a new age of fighting that combined precision weapons, unprecedented surveillance of the enemy, agile ground forces, and above all - a real-time

\footnotetext{
${ }^{10}$ Paul Virilio, trans. by Patrick Camiller, War and Cinema: The Logistics of Perception, (New York: Verso, 1989): 3 .
} 
communications network that kept the far-flung operation connected minute by minute." This sheer speed of communications can be recalled in the months that followed $9 / 11$, as

\section{Susan Sontag states:}

The preferred current American way of war-making... is waged as much as possible at a distance, through bombing, whose targets can be chosen, on the basis of instantly relayed information and visualizing technology, from continents away: the daily bombing operations in Afghanistan in late 2001 and early 2002 were directed from US Central Command in Tampa, Florida. ${ }^{13}$

This mode of seeing technologically is what Slavoj Zizek refers to as 'derealization' - a fracturing of the 'real', or what could be more precisely thought of, for the purpose of this thesis, as a fracturing of the spatial and temporal properties of the conventional battlefield. ${ }^{14}$ The work of Virilio, Zizek, and Jean Baudrillard will be referred to often throughout this thesis because these authors are the most commonly referenced sources regarding the cultural anxieties and uncertainties that I will be addressing in my filmic analyses. Virilio's Ground Zero (2002), Zizek's Welcome to the Desert of the Real (2002), and Baudrillard's The Spirit of Terrorism (2003) are all books published by Verso that

\footnotetext{
${ }^{11}$ Ibid, 20.

${ }^{12}$ Joshua Davis, “'If We Run out of Batteries, This War is Screwed.," Wired (accessed May 17, 2008) http://www.wired.com/wired/archive/11.06/battlefield_pr.html.

${ }^{13}$ Sontag, Regarding the Pain of Others, (New York: Farrar, Straus and Giroux, 2003): 67.

${ }^{14}$ In his essay, "Passions of the Real, Passions of Semblance," Zizek claims that the images of the collapse of the World Trade Center Towers were "sanitized." He states: "And the same 'derealization' of the horror went on after the WTC collapse: while the number of victims $-3,000$ - is repeated all the time, it is surprising how little actual carnage we see - no dismembered bodies, no blood, no desperate faces of dying people...in clear contrast to reporting on Third World catastrophes, where the whole point is to produce a scoop of some gruesome detail: Somalis dying of hunger, raped Bosnian women, men with their throat cuts. These shots are always accompanied by an advance warning that 'some of the images you will see are extremely graphic and may upset children' - a warning which we never heard in the reports on the WTC collapse." See Slavoj Zizek, "Passions of the Real, Passions of Semblance," in Hollywood and War: The Film Reader, ed. J. David Slocum, (New York: Routledge, 2006): 89-94. Alejandro Gonzalez Iñárritu's short film, "Mexico," featured in the 11'09"01 - September 11 (Various Directors, 2002) transnational compilation film is interesting in relation to Zizek's words since Iñárritu depicts the 'real' horrors of the attack by showing quick glimpses of amateur video depicting small human figures falling to their deaths beside the towers.
} 
concern the representation of $9 / 11$ and how this event has affected our media environment thereafter. The criticisms that these authors make about $9 / 11$ have been highly influential and inspirational in guiding the research and arguments made in this thesis, but will not provide the primary methodological approach, or the basis for further theoretical development. Their work is cited as instances of the sort of expressions of cultural dismay that are also manifested in the films and other visual texts that I am considering.

The films considered in this work are critical of the media representations associated with the Iraq war. While I am concerned with the construction of truth and reality in contemporary war representations and the deeper philosophical questions they draw out, I will not be addressing these topics at any great length. These films are not necessarily concerned with how the reality of war is captured in an image, but more about how we have access to the proliferation of war images. In this thesis, I will be accessing how new digital media are integrated in these films' formal narrative structures to produce new modes of spectatorship, representing how images are being produced and transmitted by a host of individuals with various recording media. These films highlight the discrepancies, inconsistencies, and cracks of American foreign policies and military doctrines by representing the soldier's 'on-the-ground' reality of Iraq. Davis encapsulates these disparities and states:

I tracked the network from the generals' plasma screens at Central Command to the forward nodes on the battlefields in Iraq. What I discovered was something entirely different from the shiny picture of techno-supremacy touted by the proponents of the Rumsfeld doctrine. I found an unsung corps of geeks improvising as they went, cobbling together a remarkable system from a hodgepodge of military-built networking technology, off-the-shelf gear, miles 
of Ethernet cable, and commercial software. And during two weeks in the war zone, I never heard anyone mention the revolution in military affairs. ${ }^{15}$

Davis' statement encapsulates the gap that exists between the reality of war for policymakers and those that are given the duty to carry those policies out. The realities of the war in Iraq are being represented through new digital media according to the codes and conventions of photographic realism located in early war photography. The next chapter will demonstrate how realism was established throughout the history of war photography, and how these contemporary war films adhere to these rules of realism for digital media.

${ }^{15}$ Davis, “If We Run out of Batteries, This War is Screwed”. 


\title{
CHAPTER ONE
}

\section{From Fenton to Bush: The Development of Photographic Realism}

Although I wish to emphasize the technologies of cinematic and electronic representation, those two "materialities" that constitute our current moving-image culture, something first must be said of that culture's grounding in the context and phenomenology of the photographic.

Vivian Sobchack, "The Scene of the Screen:

Envisioning Cinematic and Electronic "Presence""

$[\mathrm{B}]$ ehind the camera there must be a man's eye, and a soul.

\author{
Carl Mydan (WWII photojournalist) in Susan \\ D. Moeller's Shooting War: Photography and \\ the American Experience of Combat
}

This chapter will examine the social and aesthetic history of early war photography with special attention paid to key figures such as Roger Fenton, Robert Capa, and Joe Rosenthal. As Vivian Sobchack suggests in the quote above, contemporary digital imagery aesthetics can be traced back to photography. I will begin with a discussion of the work of British war photographer Roger Fenton, and his images of the Crimean War (1853-1856). Fenton is an important figure in the history of war photography because his are arguably the first photographic images of war - although this is disputed. The more crucial debate, however, is about the veracity of his photographs. His images prominently feature soldiers in dignified poses and landscape compositions that fail to depict any actual combat situations. Fenton's Valley of the Shadow of Death (1855) photographs are his most scrutinized images and will be discussed in terms of their highly debated photographic truth.

Similar questions of authenticity have also been raised about Robert Capa's photos of the D-Day landings at Normandy in June of 1944. In contrast to Fenton's "uneventful" photos, Capa is often praised for preserving the authenticity of chaos in his 
war images. Capa's dynamic photos are considered some of the most "truthful" images of warfare, capturing the chaos and confusion of combat. Capa's images have been very influential in providing the inspiration for numerous war films, including, most notably, the Normandy landing sequence in Steven Spielberg's Saving Private Ryan. Spielberg utilizes Capa's realist aesthetic to recreate what D-Day must have looked like, according to his few images.

Questions of "photographic truth" continue to be an issue in the debate over the authenticity of Joe Rosenthal's image, Raising of the Flag on Iwo Jima (1945), that became a mass produced symbol of American military jingoism. Rosenthal's image happens to be the subject of Flags of Our Fathers, and poses the kinds of questions raised in this thesis. The film criticizes the way the American government utilized the photograph to sell war bonds. Rosenthal's image in the film (like Fenton's and Capa's) is not merely a window into a harsh and dangerous reality, it is attached with specific economic connotations conjured by the American government. Flags of Our Fathers depicts a wartime America saturated and obsessed with images, much like the post-9/11 period and the use of patriotic imagery used by the Bush Administration to promote their "War on Terror." The film's connection to the present marks the development and persistence of a photographic style of spectacle. The film's relationship with the post9/11 period will be discussed in conjunction to the victory culture that the Bush government has promoted through the "Mission Accomplished" media event in the spring of 2003, shortly after the war in Iraq began in March of the same year, and through Thomas E. Franklin's appropriation of the Iwo Jima flag raising photo in 
Ground Zero Spirit (2001). This chapter will demonstrate how the problematic nature of "digital" representation has its origins in the 'problems' of photography itself.

\section{I: Tracing Realism in Roger Fenton's Valley of the Shadow of Death}

Roger Fenton was a British photographer for Thomas Agnew publishers and was sent to the Crimea to document the British army's participation in the war. His images of the war included numerous photographic portraits of infantry soldiers, officers, and generals, avoiding any representation of the dead, maimed and/or injured. His most controversial images are the two versions of the Valley of the Shadow Death photographs that depict cannon balls littered along a dusty landscape in two different spatial arrangements. The debates associated with Fenton and his images involve accusations of his photographs being staged to have a greater emotional impact on his audiences, and doubt over his status as "the first war photographer." These criticisms are based in the modern belief of photography's ability to simply represent reality by bearing its trace, linked to notions of human memory.

Photography's capacity to freeze moments in time became the ultimate mode of preserving what had taken place throughout the nineteenth century. Caroline Brothers quotes John Berger's evocation of the connection between photography and memory and how it came to be used primarily to 'document reality':

'With the invention of the photograph we acquired a new means of expression more closely associated with memory than any other. ...Both the photograph and the remembered depend upon and equally oppose the passing of time. Both preserve moments, and propose their own form of simultaneity, in which all their images can coexist. ${ }^{16}$

\footnotetext{
${ }^{16}$ Caroline Brothers, War and Photography: A Cultural History, (New York: Routledge, 1997): 15.
} 
Photographs, like personal memories, intervene in the temporality of the historical world, inhibiting the passing of time by "freezing" the moment. Material records (photography) and mental images (memory) of moments in time disrupt our experience of the world as a continuous, uninterrupted chronology. Photographs become visual agents that reconfigure time in fragments as physically recorded memories.

What protects the integrity of traditional photography as a "memory machine" is the notion of the photograph as a physical and tangible trace of what was once recorded before the camera's lens, unlike memories that are restricted to one's psychology. Geoffrey Batchen defines 'trace' as the fundamental concept that connects photography to its real world referents and suggests: "the word ["trace"] itself simultaneously designates both a mark and the act of marking, both a path and its traversal, both the original inscription and its copy, both that which is and that which is left behind, both a plan and its decipherment." 17

The trace of reality found in the photographic image separates it from other means of visual representation such as painting. Liz West contends that photography and painting, at one point in time, shared a very close relationship with realism:

Many historians have noted the coincidence of early photography with realism in painting in the mid-nineteenth century. Realism emphasised painting from observation, as opposed, for instance, to painting narratives from history, or to religious iconography. Realism was thus seated in empirical aesthetics. ${ }^{18}$

\footnotetext{
${ }^{17}$ Geoffrey Batchen, "Photogenics," in The Photography Reader, ed. Liz West, (New York: Routledge, 2003): 236.

${ }^{18}$ Liz West, "Reflections on Photography," in The Photography Reader, ed. Liz West, (New York: Routledge, 2003): 12.
} 
However, Gregory Currie claims that there is a basic distinction in photography's and painting's relationship with the empirical aesthetics of observation and that this lies between two realms: trace and testimony. "The painter may make a likeness of her subject so vivid and detailed that one could take it for a photograph," Currie explains, "but photography is not just a device to make paintings by cheaper and quicker means; a photograph is a trace of its subject, while a painting is testimony to it."19 Photographs, as stated before, are created as a result of a chemical reaction, light interacting with photosensitive chemicals, 'tracing' the objects and subjects that were once before the shutter's lens on a material surface. But, how does the image's relationship with reality change when what is being photographed is staged for the sole purpose of being photographed? Does this affect the integrity of the photographic apparatus as a traceable medium of reality?

Some critics insist that Fenton's carefully composed images reflect the technological complications of capturing such "privileged moments" of military combat at the time. Photographic plates restricted the speed and efficiency of the photographic process, cameras were cumbersome and heavy, and Fenton's mobility on the battlefield was limited by his methods. Fenton had used a "mobile studio," a horse-drawn carriage that contained all of his equipment for taking and developing his photographic plates, limiting his photographic reconnaissance and coverage of the war (Figure 2.1).

\footnotetext{
${ }^{19}$ Gregory Currie, "Visible Traces: Documentary and the Contents of Photographs," in Philosophy of Film and Motion Picture: An Anthology, ed. Noël Carroll and Jinhee Choi, (Malden: Blackwell, 2006): 142.
} 


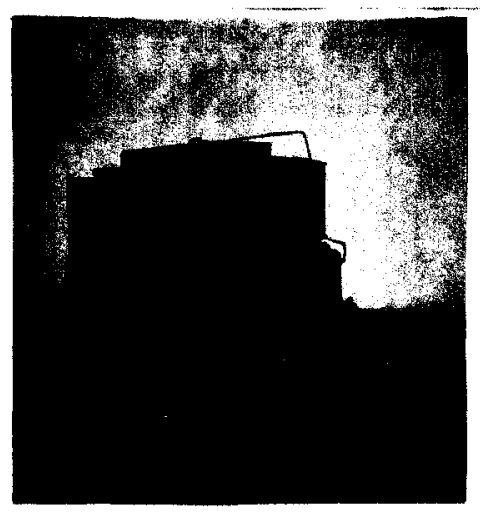

Figure 2.1 The Artist's Van (Roger Fenton, 1855)

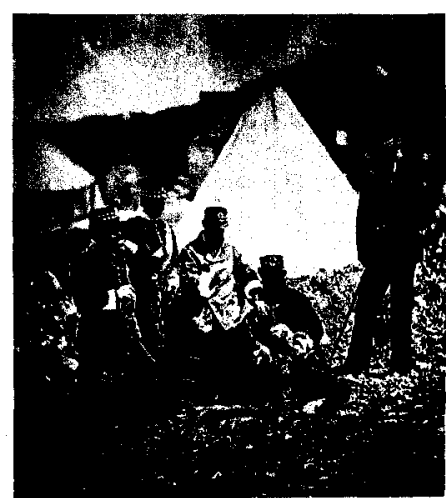

Figure 2.2 Officers of the $71^{s t}$ Highlander (Roger Fenton, 1855)

However, it has also been argued that his images maintain and propagate a strict

ideological position consistent with nineteenth-century Victorian values. Helmut and

Alison Gernsheim write that:

It is certain that [Fenton's] expedition was made under the patronage of Queen Victoria and Prince Albert, and with the assistance of the Duke of Newcastle, Secretary of State for War. On the other hand, it was financed by the Manchester publisher Thomas Agnew \& Sons, who wanted pictures of the people and scenes of historical interest, with the object of selling them to the public. It is clear that, in order not to offend Victorian ideas of good taste, Fenton had to avoid portraying the ravages of war... ${ }^{20}$

Sontag has also argued that the absence of death or combat situations in any of his photographs raise suspicions about what kinds of pictures he sought to capture:

Under instructions from the War Office not to photograph the dead, the maimed, or the ill, and precluded from photographing most other subjects by the cumbersome technology of picture-taking, Fenton went about rendering the war as a dignified all-male group outing. ${ }^{21}$

Out of more than 200 photos taken by Fenton, not one depicts the death or suffering of men, women, children, or even the enemy. Sontag's description of the view of the

\footnotetext{
${ }^{20}$ Helmut and Alison Gernsheim, Roger Fenton, Photographer of the Crimean War; His Photographs and his Letters from The Crimea, (New York: Arno Press, 1973): 13.

${ }^{21}$ Sontag, Regarding the Pain of Others, 49-50.
} 
Crimean war as "a dignified all-male group outing" is characteristic of Fenton's decorum, privileging portraits of English Lieutenants, Generals, and Captains (Major General Estcour (1855), Captain Halford (1855)) and all-male group shots (Major Gen.l Garrett \& Officers of his Staff (1855), Officers of the 71st Highlanders (1855)) (Figure 2.2). ${ }^{22}$

Fenton had been initially hailed as the "first war photographer" but this has now been revised by some critics. The Gernsheims argue that Fenton's designation as the first war photographer "is a fallacy." 23 This title is argued to apply more appropriately to Karl Baptist von Szathmari, an amateur painter and photographer living in Bucharest who was able to photograph the Russian army's entrance into the Crimean War. His photos were never exhibited in England like Fenton's were in 1855, but were showcased at the Universal Exhibition in Paris of the same year. Nonetheless, Fenton's images are important because they achieved a high level of realism and verisimilitude that artists of the visual arts had strived to achieve for centuries. ${ }^{24}$ However, even the status of photographic evidence is not always clear.

The arbitrariness of photographic evidence and Fenton's images are discussed at length by Errol Morris in an article published for The New York Times about Morris's investigations into the two versions of Fenton's Valley of the Shadow of Death. ${ }^{25}$ Both

\footnotetext{
22 "Roger Fenton," George Eastman House, Still Photograph Archive (2003). http://www.geh.org/fm/fenton/htmlsrc/fenton_idx00001.html (accessed January 26, 2008).

${ }^{23}$ Gernsheim, Roger Fenton, Photographer of the Crimean War; His Photographs and his Letters from The Crimea, 10.

${ }^{24}$ In his famous essay, "The Ontology of the Photographic Image", André Bazin argues that "painting was torn between two ambitions: one, primarily aesthetic, namely the expression of spiritual reality wherein the symbol transcended its model; the other, purely psychological, namely the duplication of the world outside". Photography, initially, leaned to the latter of the two ambitions, to sufficiently duplicate the world. This essay and quote is taken from Bazin, André, What is cinema?, (Berkeley: University of California Press, 2004): 11.

${ }^{25}$ Errol Morris, "Which Came First, the Chicken or the Egg? (Part One)," The New York Times (September 25, 2007). http://morris.blogs.nytimes.com/2007/09/25/which-came-first-the-chicken-or-the-egg-part-one/
} 


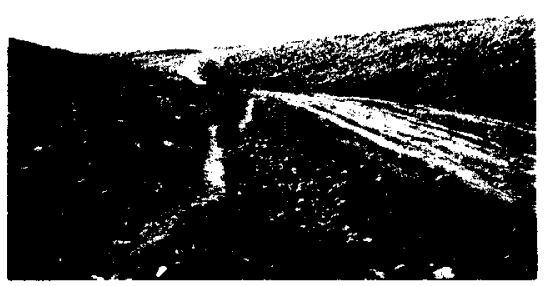

Figure 2.3

"OFF" (Roger Fenton, 1855)

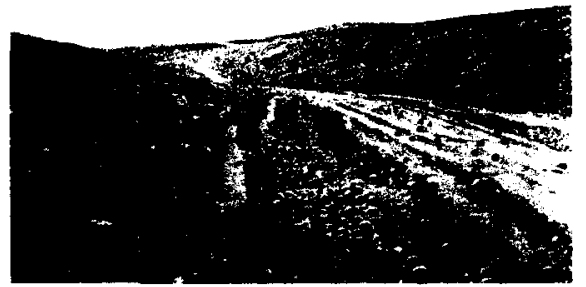

Figure 2.4

"ON" (Roger Fenton, 1855)

photographs are taken from identical vantage points, depicting a collection of cannon balls littered along the surfaces of a dry and war ravaged landscape. Morris refers to one version as the "OFF" image and the other as the "ON" image ("OFF" refers to the shot with cannon balls "off" the road, and "ON" refers to the one with cannonballs featured "on" the road) (Figure 2.3 and Figure 2.4). The "OFF" photograph is popularly thought to be the one that was taken first by Fenton, and later, having someone rearrange the placement of the metal objects "on" the road for the more "dramatic" second photo. And there are others that believe that it is the other way around, that the "ON" was taken first, before the "OFF" photograph.

However, Morris is highly critical of both hypotheses, since much of the theorization on the ordering of the images is purely speculative, lacking any substantial evidence. Morris states:

(accessed January 26, 2008). It should be noted that this article is a part of a series that Morris had produced for The New York Times that include two other equally fascinating and rigorously researched pieces - part two was published online on October 4, 2007 and part three on October 23, 2007. In the other articles, Morris goes above and beyond in his investigations by making a visit to the site of the photographs, reenacting the photos in the present, and even uses sun-map software to calculate the time of day of the photographs by analyzing the difference in the shadows cast by the cannon balls in each image, which Morris believes is the key to solving the enigma of Fenton's photographs. 
Much of the problem comes from our collective need to endow photographs with intentions - even though there are no people in the frame, including Fenton himself, who is conspicuously absent. The minute we start to conjecture about Fenton's reasons, his intent - his psychological state - we are walking on unhallowed ground. Can we read Fenton's intentions off of a photographic plate $?^{26}$

Morris suggests that images do not exist as just images, but they are accompanied by a series of institutional speculations and explanations that seek to contextualize them in a specified socio-cultural milieu. Despite the ordering of the "OFF" and "ON" images, the notion that images are incomplete by themselves is something that is certainly true of later war images that included Capa's and Rosenthal's. Whatever the real ordering of the Valley of the Shadow of Death photos is, the most important point for this thesis in Morris's investigations is that images require explanations - by themselves, they do not really tell us much. Photographs are contextualized to mean specific things to different people at various points in time.

\section{II: Changing Notions of War Realism and Robert Capa}

Robert Capa was a photographer for Life magazine when he was given the duty to capture as many images as humanly possible of the Allied offensive on D-Day (June 6, 1944). His notion of realism in his most famous photographs of the Normandy landings is radically different than Fenton's. The realism sought by Capa is unsettling, gritty, and immediate. His D-Day photos contain "motion blurs" caused by sudden, jerky camera movements and feature out-of-focus planes of action, understood to signify a nervous and scared photographer caught in the middle of combat chaos. The motion blurs rendered in

\footnotetext{
${ }^{26}$ Ibid.
} 
Capa's war images articulate much of the drama captured in his candid moments and are some of the most prominent examples of war photography realism - an aesthetic later adopted by many war films. The chaos of combat is simulated through the "amateur" aesthetics that evoke the notion of a man snapping any shots he could get without becoming war's next victim. Capa's photos lack the staged qualities of Fenton's work. Capa famously said: "If you're pictures aren't good enough, you aren't close enough.",27 Capa's unnerving closeness to war produced photos that appear to be right in the thick of battle, side by side with the soldiers moving further into enemy territory. Capa's work evokes an immediate realism, a sense that Capa was in real danger in his efforts to capture the disarray that surrounded him. However, the problems with his photos are that they have been highly scrutinized by many critics and scholars as being romanticized depictions of combat. Some believe that Capa could have easily simulated this 'amateur' aesthetic to dramatize the subject of his images.

"For the first time," Bazin explains in the context of photography, "between the originating object and its reproduction there intervenes only the instrumentality of a nonliving agent. For the first time an image of the world is formed automatically, without the creative intervention of man." 28 But the authenticity of Capa's images relies heavily upon their subjectivity. Alex Danchev explains that "Robert Capa touted his celebrated sequence of the D-Day landings in 1944 as 'a cut-out of the event which will show more of the real truth of the affair to someone who was not there than the whole scene.,",29

\footnotetext{
${ }^{27}$ Peter Howe, Shooting Under Fire: The World of the War Photographer, (New York: Artisan, 2002): 18.

${ }^{28}$ Bazin, What is cinema?, 13.

${ }^{29}$ Alex Danchev, "War Stories," in The Journal of Military History 69:1 (January 2005): 213.
} 
These photos have been hailed as some of the first war images to render the brutality of the war experience on film. Initial publications of the photographs in Life magazine included captions that suggested that the poorly focused images were a result of a "nervous" photographer - a caption of one of his images featured in the magazine read that "'immense excitement of [the] moment made Photographer Capa move his camera and blur [his] picture." ${ }^{30}$ The people at Life claimed that the blurs found on the photos were a result of Capa's trembling hands. These romantic notions of the unification of Capa's camera and body on D-Day anthropomorphize the photographic apparatus, making it less of a distinct mechanical object and more of an extension of the camera operator's nervous system. ${ }^{31}$ But, to what degree do these motion blurs actually reproduce Capa's physical and mental state on film?

Some scholars have criticized Capa's narrative for not telling the entire truth behind the heightened sense of realism achieved in his images. Capa had taken a total of seventy-two photos that day, later learning that eleven were actually able to be developed. It is not that Life magazine thought that the other sixty-one photos were not any "good," but that the images were victims of a fatal mistake in a London photo lab (due to an overheated drying cabinet), while only a handful of photos were mildly damaged - these are the photos that were developable. ${ }^{32}$ Some skeptics have attributed the blurriness of his

\footnotetext{
${ }^{30}$ Robert Whelan, Robert Capa: A Biography, (Lincoln: University of Nebraska, 1994): 198.

${ }^{31}$ Patricia R. Zimmerman said that "World War II anthropomorphized cameras." See Patricia R. Zimmerman, Reel Families: A Social History of Amateur Film, (Indianapolis: Indiana University Press, 1995): 98.

32 According to Whelan, Capa's photos were compromised by Life magazine developers, Hans Wild and Dennis Sanders, in a London developing lab. Whelan explains, "When the negatives [of Capa's D-Day photos] came out of the developing solution, Wild told [John] Morris that they were fabulous. Morris responded, 'Rush me prints!' A few minutes later, Sanders burst into Morris's office, blurting out hysterically, 'Capa's films are ruined; they're all ruined." (198) Whelan explains that "[o]f the seventy-two
} 
photos not to his physical uneasiness, but rather, to this accident in the development stage since his photos could have easily been underdeveloped, creating the now famous blurry impressions (Figure 2.5 and Figure 2.6). Danchev states: “'Realism' in war photography is a genre, rather like the 'hardboiled' mystery novel. Naturalism is a false nose. The pain of others may be exposed in the darkroom; but it is only a fleeting glimpse." ${ }^{33}$ Do Capa's images serve as a convenient reminder for the chaos of that day or is this the perpetuation of what Life magazine thought that D-Day ought to look like? Cinema has always carried out this tradition of photographic realism inspired by Capa's D-Day images in the hopes of capturing an 'unmediated' representation of reality.

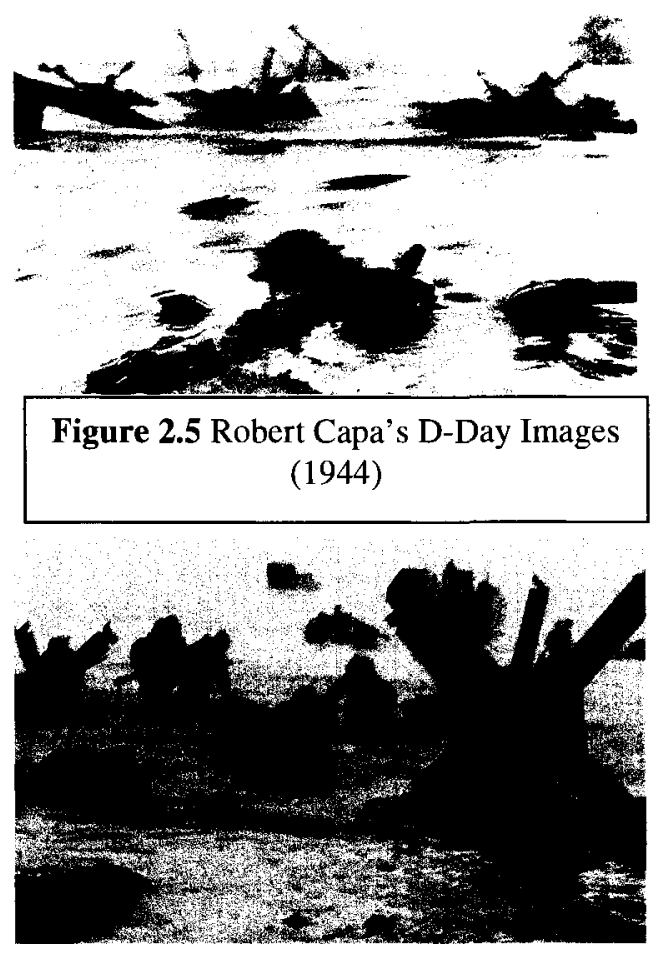

Figure 2.7 Saving Private Ryan (Steven Spielberg, 1998)

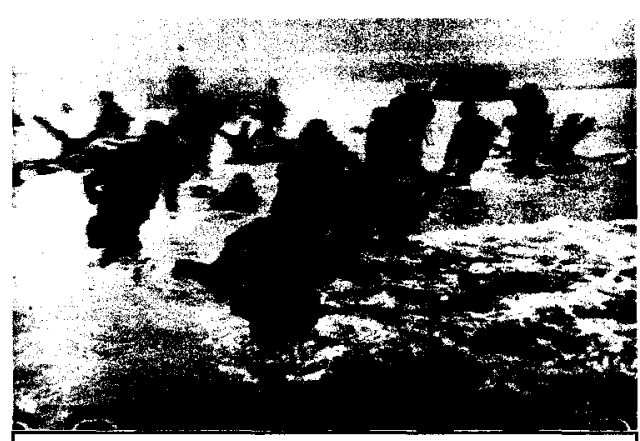

Figure 2.6 Robert Capa's D-Day Images

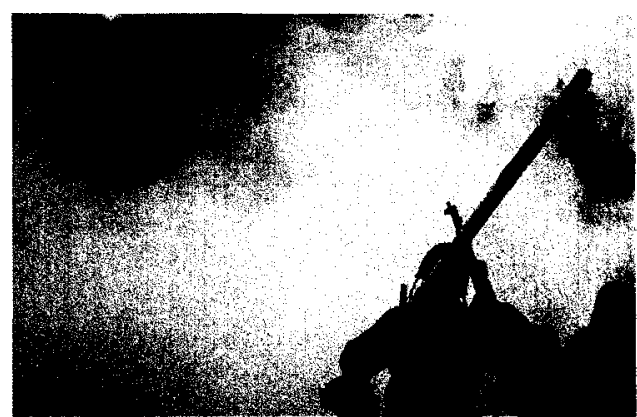

Figure 2.8 Saving Private Ryan

images on the two rolls of $35 \mathrm{~mm}$ film that Capa had shot with his Contaxes during the landing, eleven pictures were printable." (198)

${ }^{33}$ Danchev, "War Stories," 213. 
The influence of Capa's war realism can be seen in the Normandy landing sequence of Steven Spielberg's Saving Private Ryan (1998) (Figure 2.7 and Figure 2.8). J. David Slocum explains the contradiction of war image making and how it seeks to reproduce the reality and experience of 'real' warfare:

Watching battle, its pain and carnage, from a distance sufficient to maintain one's own physical safety produces a "terrible beauty" and the basis of intense and seductively enjoyable sensations that have been called the "destructive sublime." Yet both the sense-making and visual pleasures have always been complexly related to the ideological preoccupations imparted through specific representational, institutional, and commercial practices and strategies. Cinematic representation provides neither a neutral lens through which to observe war nor a straightforward reflection of the political or economic predispositions of the historical period of production. ${ }^{34}$

Despite the controversy that had gathered around the authenticity of Capa's photos, the landing on Omaha Beach in Saving Private Ryan was shot with Capa's stark photos in mind. Spielberg commented in an issue of DGA Monthly on the inspiration of the gritty realism that Capa's D-Day photos provided for principal photography of the landing sequence:

...the things that informed me more than anything else were those surviving snapshots of Omaha Beach taken by the famous war photojournalist Robert Capa. I had ...those pictures hung up on my bulletin board in my office, and also at home, and I stared at them relentlessly and told my group that I wanted to re-create the feel in every single one of those photographs. ${ }^{35}$

Spielberg's camera closes in on the eyes of an older Private James Ryan (Harrison Young) as he stares towards the rows upon rows of white crosses that mark the resting places of

\footnotetext{
${ }^{34}$ J. David Slocum, "General Introduction: Seeing Through American War Cinema," 17.

${ }^{35}$ Andrew Levy, "Saving Private Ryan," DGA Monthly (January 1999). http://www.dga.org/news/features/saving_private_ryan.php3 (accessed January 27, 2008).
} 

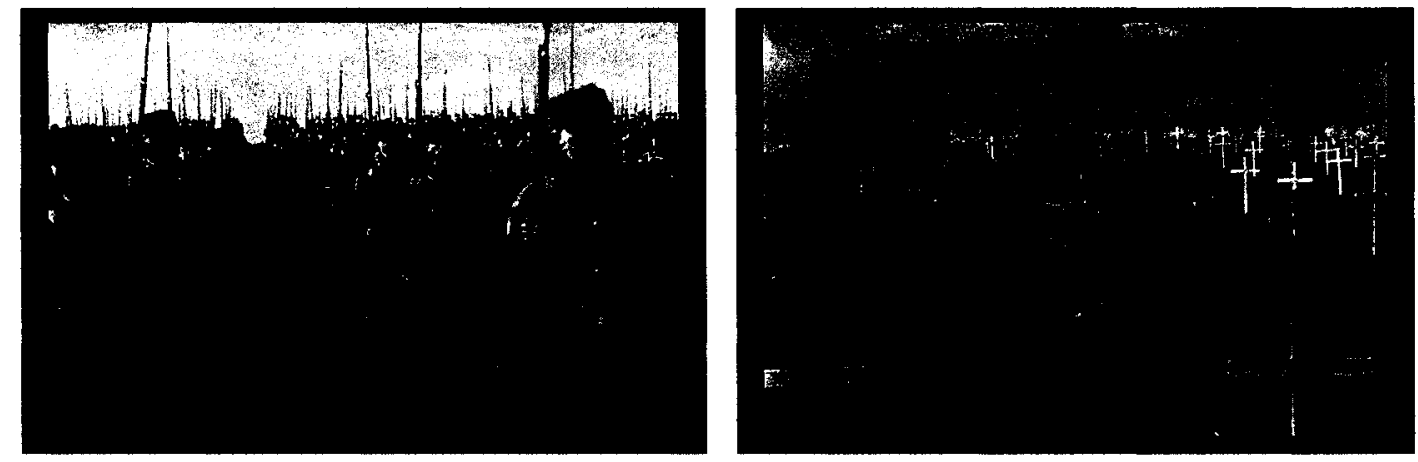

Figure 2.9

Les Croix de Bois (Wooden

Crosses) (Raymond Bernard, 1932)

Figure 2.10

Les Croix de Bois (Wooden Crosses)

the men who lost their lives in WWII, recalling similar imagery from Raymond Bernard's WWI picture, Les Croix de Bois (Wooden Crosses) (1932), where rows of military soldiers appear to dissolve into rows of small white wooden crosses (Figure 2.9 and Figure 2.10). Cutting to a deeply focused shot of waves crashing against endless rows of "Czech hedgehog" obstacles, a massive sea brigade of American and allied soldiers are now shown making their way to the shores of Omaha beach. Captain John H. Miller (Tom Hanks) looks down at his trembling hands as many of his men in his landing craft vomit to the alarming sounds of bombs and gun fire that increase in volume and frequency as they approach their destination. The gate to the craft suddenly drops, propelling Miller's men into combat as they are confronted with a wave of enemy fire, triggering the sequence's Capa-inspired photographic realism. Spielberg's camera recreates the experience of "being there" - his camera lens is sprayed with fragments of blood and flesh from fallen men, falling in and out of the blood soaked water as bullets buzz by, bobbing up and down in sudden maneuvers through the active battleground. 
Spielberg's pursuit of realism is based on myths of truth associated with Capa's photographic imagery. Geoff King explains that Saving Private Ryan presented a shift in the tradition of the Hollywood war film: "the opening D-Day landing sequence of Saving Private Ryan... is an assault on the viewer almost as much as on the beaches of Normandy," and adds: "we are not meant to wallow in the glorious sensual experience of Hollywood-created warfare but to be stunned by a sense of what the 'real event' must have been like." ${ }^{, 36}$ Patricia Zimmerman writes that as early as WWII narrative cinema, fictional war films have simulated a documentary appearance. Zimmerman explains [L]ightweight hand-held $16 \mathrm{~mm}$ and $35 \mathrm{~mm}$ cameras - more flexible than tripod-mounted $35 \mathrm{~mm}$ DeVry cameras - bounced, shook, and quivered during turbulence, antiaircraft fire, or fierce combat. James Wong Howe in Howard Hawk's Airplane even simulated this turbulence in the interior plane shots by shaking the camera. This "camera rattling," formerly an amateur transgression against Hollywood conventions of unified composition and organization, was reinterpreted as experiential, audience-directed, participatory realism when employed in commercial films. ${ }^{37}$

In what may appear as a contradiction, Spielberg's sequence is exemplary in the pursuit of destroying the object of the screen, attempting to recreate an 'unmediated' representation and inviting spectators to, like Capa did, see how war feels.

One cannot omit the problems with trying to represent the 'real' horrors of D-Day in light of the heavy constructedness of Spielberg's thoroughly planned and researched filmic style utilized for the sequence. The opening to Saving Private Ryan is not any more 'real' than the "glorious sensual experience of Hollywood-created warfare" that King

\footnotetext{
${ }^{36}$ Geoff King, "Seriously Spectacular: "Authenticity" and "Art" in the War Epic," in Hollywood and War: The Film Reader, ed. J. David Slocum, (New York: Routledge, 2006): 287, 288-289,.

${ }^{37}$ Zimmerman, Reel Families: A Social History of Amateur Film, 105-106.
} 
explains audiences were used to witnessing in the Hollywood war film. ${ }^{38}$ F.E. Sparshot argues that photography is often misconceived as a medium that simply reproduces reality: "When photography was invented it was hailed as reproducing vision, but that is not what it did. What it really accomplished was the realization of an ideal of vision."39 Spielberg's D-Day landing is based on an idealized realist aesthetic rooted in the mythology of the "transparent reality" associated with Capa's photos. Photography's realization of "an ideal of vision" can also be seen in Joe Rosenthal's Raising of the Flag on Iwo Jima image.

\section{III: Raising Flags on Mount Suribachi and Ground Zero - Flags of Our Fathers}

Joe Rosenthal was an Associated Press photographer for the American military during WWII and shot the famous Raising of the Flag on Iwo Jima photograph that was used to sell victory bonds throughout the remainder of the war (Figure 2.11). The photo

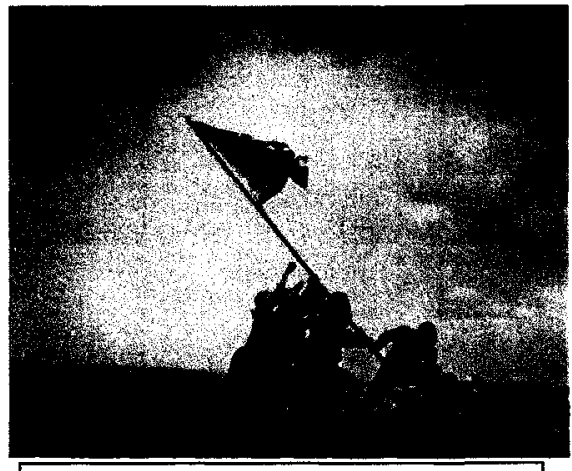

Figure 2.11 Raising of the Flag on Iwo Jima

(Joe Rosenthal, 1945) depicts a group of men jointly raising an American flag on the hilltop of Mount Suribachi, a key event in the battle of Iwo Jima. The main problems surrounding Rosenthal's image is that the photograph became the most important icon for the American government to represent their role in the

\footnotetext{
${ }^{38}$ One may recall the frequent use of aerial cinematography, cranes and tracking shots used in Apocalypse Now (Francis Ford Coppola, 1979) or Stanly Kubrick's signature stedicam in Full Metal Jacket (1987) to achieve smooth, fluid, and spectacular camera movements that can also be seen regularly in The Shining (1980) or Eyes Wide Shut (1999).

${ }^{39}$ F.E. Sparshot, "Vision and Dream in the Cinema," in Philosophy of Film and Motion Picture: An Anthology, ed. Noël Carroll and Jinhee Choi, 83 (Malden: Blackwell, 2006).
} 
war to the public, neglecting any visualization of the soldiers' hardships, grief, and disillusionment associated with the battle. These issues are central to Eastwood's Flags of Our Fathers, a film explicitly about the problems of photographic representation in Rosenthal's image and the realities of the war it failed to depict.

Flags of Our Fathers is the first of two war films (the other being Letters From Iwo Jima) released in 2006 that he co-produced with Steven Spielberg about the battle of Iwo Jima. In Flags of Our Fathers, the surviving men within the photograph are commodified as symbols of American strength and perseverance during a time of political and financial uncertainty. The development of a 'patriotic' photographic style associated with Rosenthal's image has continued to be exploited in the post-9/11 period, where similar types of imagery are being used by the Bush Administration to valourize the American mission in Iraq. Flags of Our Fathers is critical of the ideological implications of Rosenthal's image, presenting the pain and suffering of the surviving men in the photograph. It is a film released in an era where similar images are being used to sell another idealized view of war to the American public.

The release of Letters from Iwo Jima has proven to be more commercially and critically successful when compared to Flags of Our Fathers. Leo Braudy insists:

Letters has received a lot more of the press and critical attention than Flags, the most expensive film Eastwood has yet made, which appeared to great critical fanfare and appreciation in October 2006 but never found an audience, perhaps because it was shunned by both the supporters and detractors of the Iraq war: too jaundiced about patriotism for the pro-war crowd and too much of a war film for those disillusioned with the war. ${ }^{40}$

\footnotetext{
${ }^{40}$ Leo Braudy, "Flags of Our Fathers/Letters From Iwo Jima," in Film Quarterly 4 (2007): 16.
} 
Braudy's comments suggest that Flags of Our Fathers is neither a straight-forward war film nor anti-war film, but that it can be considered to contain elements of both generic modes. This can be seen in the film's narrative structure, which shifts between the present and the past. Eastwood's narrative offers a complex oscillation between the present day activities of James Bradley, a son of one of the men depicted in Rosenthal's image, who is interviewing veterans for his book about WWII, and the journey of Rene Gagnon (Jesse Bradford), Ira "Chief" Hayes (Adam Beach), and John "Doc" Bradley (Ryan Phillippe), three of the surviving members of the photo, promoting the sale of war bonds on the home front. The opening of the film depicts an older man passing by a series of coffins, accompanied by a voice over that explains, "we like things simple." The man collapses on a set of stairs and mumbles various words that are barely coherent. This scene characterizes the post-traumatic stress that many war veterans suffered soon after the war; in this case, the man is the elderly 'Doc' Bradley. Our narrator is revealed to be one of 'Doc' Bradley's son's interviewees, a war veteran. The man sits in a dimly lit room against a backdrop of war paraphernalia that includes a tattered Japanese flag, a reproduced flag-raising publicity poster, and various old military photos. "I'd tell their folks that they died for their country," adds the vet, "but I'm not sure that was it. What we see and do in war, the cruelty, is unbelievable, somehow we gotta make some sense of it, to do that, we need an easy to understand truth."

This "easy to understand truth" is Rosenthal's photograph, now shown being developed in a darkroom (Figure 2.12). Shortly thereafter, in a montage sequence, the photograph is seen reproduced on the front pages of The New York Times, The Los 


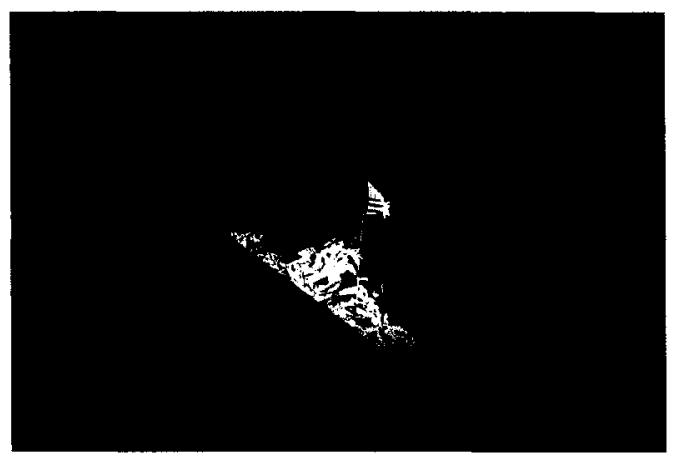

Figure 2.12 Flags of Our Fathers (Clint Eastwood, 2006)

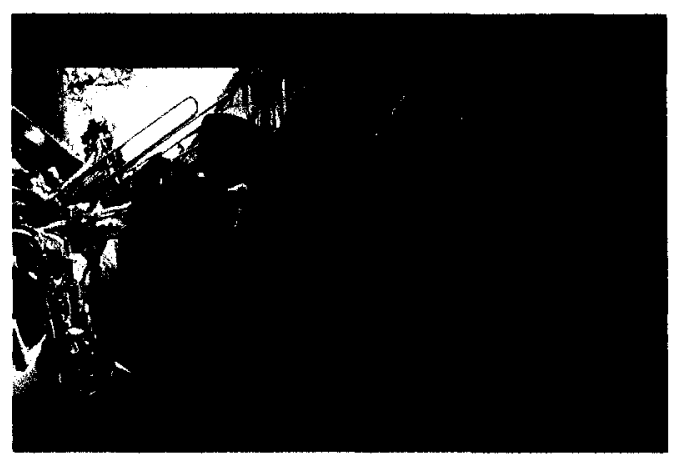

Figure 2.14 Flags of Our Fathers

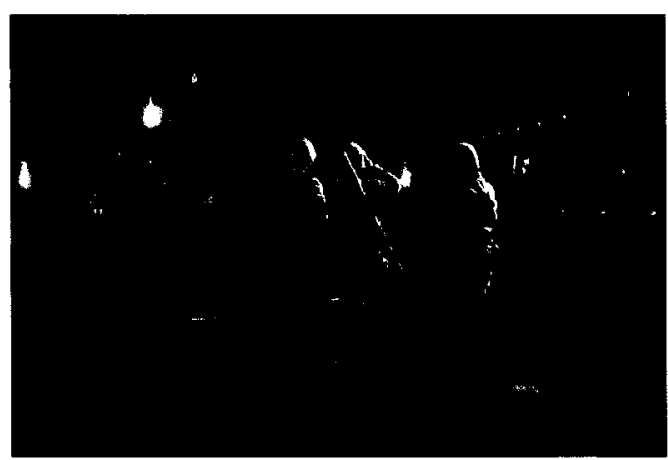

Figure 2.13 Flags of Our Fathers

Angeles Times, and placed on the desk of President Truman at the White House. This sequence conveys the high degree of reproducibility and publicity that was attached to the public release of the photograph. Numerous celebratory sequences depict the spectacle of military

ideology. These include the dramatic reenactment of the flag planting before a stadium of thousands of cheering Americans against a massive display of fireworks, Rene's homecoming at a train station where he is swarmed by flag wavers, and the mens' guest appearance at Times Square accompanied by a trio performing the "Victory Polka" (Figure 2.13 and Figure 2.14). These scenes reflect the repackaging of the men's identities as stars and celebrities through the organization of public spectacles to sell victory bonds. The film's narrator explains, "everybody who saw that picture thought planting the flag meant victory, that's all they wanted to know, victory." 


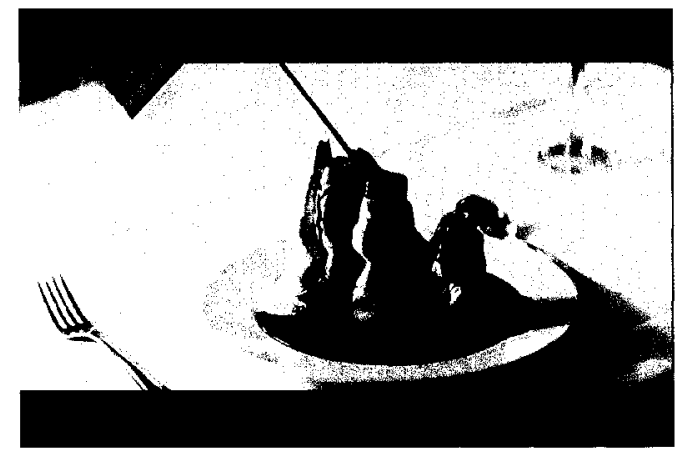

Figure 2.15 Flags of Our Fathers

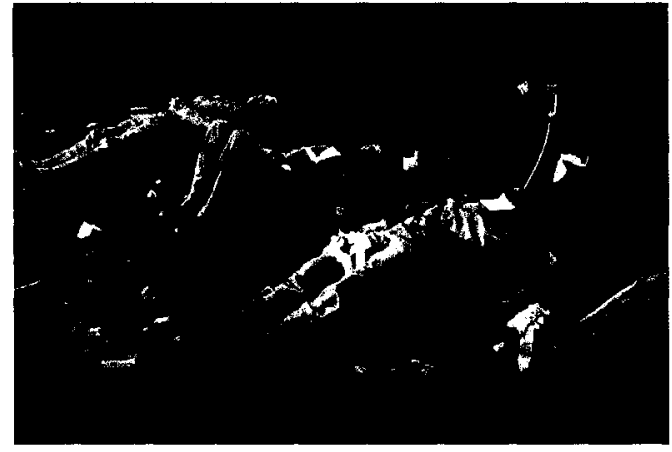

Figure 2.16 Flags of Our Fathers

The sensationalized perception of victory evident in Flags of Our Fathers is juxtaposed with the film's reversions to flashbacks of soldiers on the island of Iwo Jima, depicting a battle that involved much more than the raising of a flag. Ira's remembrance of a soldier's frenzied assault on a group of deceased Japanese soldiers and Doc's recollection of the wounded and dismembered soldiers brought on by the pouring of strawberry sauce over "flag raising" ice cream remind the viewer that the photo could never capture the full bloodshed and brutality of their war experience (Figure 2.15 and Figure 2.16).

Photographs are never a neutral, transparent record of reality, reinforced in the case of the flag raising image that visually ignores the other horrors of war. The Rosenthal photograph represents the presence of collective male bravery in the face of the chaos, but leaves the bloodshed and carnage of war absent, as Eastwood reminds his viewers. Sontag describes the paradox of photography and the gap between images and the realities they contend to "reproduce": "In the first of the six essays in On Photography (1977), I argued that while an event known through photographs certainly becomes more 
real than it would have been had one never seen the photographs, after repeated exposure it also becomes less real." culture of spectatorship neutralizes the moral force of photographs of atrocities" is not entirely true, opposing Baudrillard's notion of images that "assumes... everyone is a spectator", and that no one lives these events. ${ }^{42}$ The film's flashback structure is used to remind the viewer that these men lived the war, and did not simply climb a mountain to raise a flag on Japanese soil.

The film's many reenactments of the way victory looked in WWII America (parades, dinner celebrations, public media events) is reflective of how the Bush administration carefully crafts the image of "victory" for the media - that they are succeeding in their 'humanitarian' efforts. One of the most prominent images depicting the spectacle of post9/11 American triumph was George Bush's landing on the USS Abraham Lincoln Naval Carrier on May 1, 2003. Evans Chan argues how the Bush Administration has chosen to display the movement towards success of operations in the Middle East through the means of visual spectacle:

... [George W. Bush's] management players have done a relentless packaging job by recruiting the best TV team to work on lighting, camera angles and "set design" for every presidential appearance. And the White House's imaging assault has intensified since September $11 \ldots$. For the televised speech to the nation that Bush gave on the anniversary of the Sept. 11 attacks, the White House added its Speer touch- three barges of giant Musco lights, the kind of Klieg Lights used by event organizers to illuminate movie premieres, rock concerts and sports stadiums, were launched across New York Harbor to light up the 305-feet-tall Statue of Liberty as the backdrop of the presidential address. ${ }^{43}$

\footnotetext{
${ }^{41}$ Sontag, Regarding the Pain of Others, 105.

${ }^{42}$ Ibid., $105,110$.

${ }^{43}$ Evans Chan, "War and Images," 22.
} 
The substance of the speech that Bush gave on the naval carrier was anticipated by the President's grand and illustrious arrival. Donning full naval pilot gear, Bush emerged "from [the cockpit of] a jet plane with "Navy One" and "George W. Bush, Commanderin-Chief” logos. ${ }^{44}$ Douglas Kellner describes Bush's convincing performance on that day:

Delivering a canned speech from a podium with a giant banner proclaiming "Mission Accomplished" behind him, Bush declared that the "major combat operations in Iraq have ended. In the battle of Iraq, the United States and our allies have prevailed." 45

However, this proclamation of American military success appears especially shortsighted considering the reality that the war in Iraq rages on to this day, five years after Bush's declaration of victory. Glenn Kutler writes in Orbis, the Foreign Policy Research Institute's quarterly journal, that the exponential rise in US wounded and killed in Iraq from the first year of operations starting in March of 2003, extending to March of 2004, to the second year of operations ending in March of 2005, just short of two years after Bush's "Mission Accomplished" speech:

U.S. fatalities for the second year of the war, ending March 19, 2005, were 936, more than one and a half times those of the first year. The number of wounded increased almost three times in the second year, to nearly 8,500, from nearly 3,000 in the first year. The total number of casualties multiplied more than two and a half times, from above 3,500 to more than 9,000. Thus, the second year constituted a major escalation of the war. ${ }^{46}$

While thousands of more US soldiers were continually confronted with deadly force, Bush's media event constructed the image of victory to be seen and disseminated along

\footnotetext{
${ }^{44}$ Douglas Kellner, "Bushspeak and the Politics of Lying: Presidential Rhetoric in the "War on Terror",", in Presidential Studies Quarterly 37:4 (December 2007): 637.

${ }^{45}$ Ibid., 637.

${ }^{46}$ Glenn Kutler, "US Military Fatalities in Iraq: A Two-Year Retrospective," Orbis (Summer 2005), 530.
} 
multi-national news networks, reinforcing the idiom, "for men at war, the function of the weapon is the function of the eye."47

The USS Abraham Lincoln event was coordinated by bureaucrats to inspire viewers to trust that the current government administration had succeeded in their highlyscrutinized efforts at home and on the world stage. Baudrillard noted that the careful construction of information, by governments for instance, "represents the most effective machinery for de-realizing history."48 The landing event exemplified the ideological spirit of the Bush Administration's great optimism about progress in the "War on Terror". Similarly, Rosenthal's photograph depicts an event that was staged for his camera's gaze the flag raising in this image was actually the second raising of the American flag on Mount Suribachi, constructed for the camera as an image of victory.

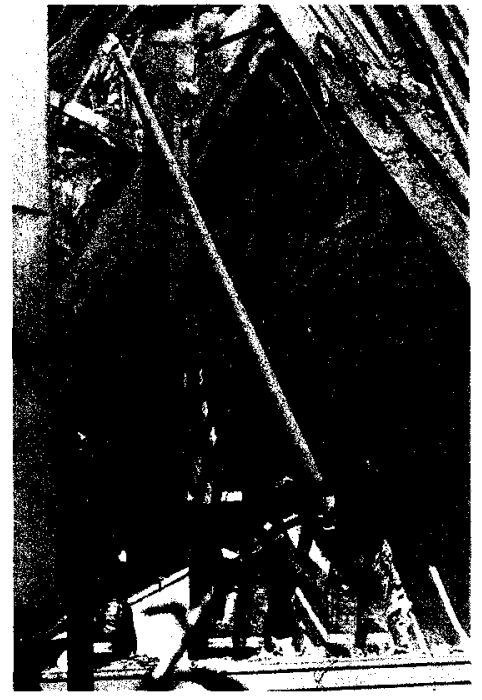

Figure 2.17 Ground Zero Spirit

(Thomas E. Franklin, 2001)

In what became a symbolic image for Americans of the efforts of the New York City emergency services on 9/11, Thomas E. Franklin's Ground Zero Spirit explicitly evokes the staging of the Iwo Jima flag raising (Figure 2.17). Oddly enough, Franklin's picture depicts three firefighters raising the American flag on a slanted pole before a backdrop of structural debris. Like the Rosenthal image, Ground Zero was reproduced on the covers of newspapers and magazines around the world and eventually became a commemorative stamp for the United States Postal

\footnotetext{
${ }^{47}$ Virilio, War and Cinema: The Logistics of Perception, 20.

${ }^{48}$ Jean Baudrillard, The Intelligence of Evil or the Lucidity Pact, (New York: Berg, 2005), 121.
} 
Service, renamed "Heroes 2001". Marguerite Helmers and Charles A. Hill explain the contrast of the subjects depicted in both images:

'Rosenthal's picture spoke of group effort, the common man - working in concert with his neighbours - triumphant. The very facelessness of the heroes sanctified a common cause.'... Franklin's photograph of the three firefighters shifts the emphasis from military might to the exemplary duties of the common man. ${ }^{49}$

Franklin's photo reflects a patriotic and dutiful response to a catastrophic event, men working together to rise above the chaos perceived in the heap of metal and cracked concrete of what once belonged to two of America's largest structures. Similar to Fenton's and Capa's images, this photo marks a preferred and idealized type of realism, representing the determination and the driving professionalism of national heroes.

Arvind Rajagopal suggests that after September 11, American news media politically slanted in favour of US foreign policy. Rajagopal contends that "critics of proUS media coverage have frequently described such coverage as 'patriotic' or at times, ‘jingoistic'."50 Franklin's photograph conjures up notions of patriotism, but also, nationalism. Rajagopal states: "Patriotism refers to the sentiment subjects have for king and country, ... nationalism refers to people's relationship with each other... .,51 Franklin's image parallels the post-9/11 pro-US media nationalist rhetoric that Rajagopal refers to, signifying the intersection of patriotism and nationhood. The men in the photo are united in a collaborative effort, staring upwards in admiration at the ascent of a national symbol, the American flag. However, many other activities and events that are

\footnotetext{
${ }^{49}$ Marguerite Helmers and Charles A. Hill, eds. Defining Visual Rhetorics, (Mahwah, NJ: Lawrence Erlbaum Associates, 2004), 8.

${ }^{50}$ Arvind Rajagopal, "A Nation and its Immigration: The USA After September 11," in Media and Culture Theory, ed. James Curran and David Morely, 77, (New York: Routledge, 2006).

${ }^{51}$ Ibid., 77.
} 
not symbolized in the photo had transpired in New York City in the weeks that coincided with the publication of Ground Zero Spirit. 9/11 also fractured a nation. As Rajagopal notes,

thousands of foreigners and/or immigrants were being arrested and detained without charges. Many of them were denied legal representation and deported summarily. ... such events fell into the category of local or domestic news and, ...could not be seen as tied to nationalist politics being pursued abroad. ${ }^{52}$

As a nation was growing divided along boundaries of race, ethnicity, and religion, the construction of a united America proliferated in mainstream media images, propagating the fact that Americans would undoubtedly stand together against foreign 'intruders.'

The idea of a cohesive and unified America is questioned in Flags of Our Fathers. Ira, being the only visible minority figure in the film, is constantly discriminated against by his fellow soldiers and by the American public upon his return. On the eve of the first landings on Iwo Jima, a group of men play cards below deck while Ira is visually separated from the group as he sorts through a series of photographs on his bunk. One of the men interrupts Ira and asks, "Is that your girlfriend Chief?," and adds, "Bet she's a pretty damn good looking sqauw." Later as the bond drive is fully underway, Ira is thrown out of a late night cocktail bar that showcases the Iwo Jima photo beside their front entrance. Ira points to the barman and explains, "He didn't serve me." The man responds to Ira with a patronizing glare, "We don't serve Indians." America is not presented as an inclusive and unified nation, unlike what we see in Rosenthal's and Franklin's images. Ira is treated as an outsider to the exclusive grouping of an all-white America, reinforced by his dislike for the young, white American hero, Rene, the undisputable poster child for the

${ }^{52}$ Ibid., 77. 
bond drive. The disparities between heroes and their acceptance on the home front delineate the problematic rendering of a unified wartime America.

The film further problematizes the common integration of what is often depicted as a basic ideological structure of the classical American war film: male camaraderie. Slocum quotes Susan Carruthers' statement claiming how war films often work to emphasize the homosocial bonding of men of war:

All that matters is obeying orders; fighting courageously to save one's life and, more heroically, those of other men. War is reduced to a primal struggle to stay alive, to get back home, to 'leave no man behind.' And while specific wars may not amount to sacred duties, nevertheless, by definition doing one's duty is good. ${ }^{53}$

This "leave no man behind" idiom is actually the promotional tagline for Black Hawk Down (2001), a film that negates the socio-political context of the film's historical event in favour of more screen time devoted to depicting the loyalty and allegiance that marines have for one another. Flags of Our Fathers does contain such moments that appear to fall in line with the representation of male camaraderie. In the last depiction of the three men raising the flag in "Soldier Field" (a football stadium), the deaths of Sergeant Michael Strank (Barry Pepper), Harlon Block (Benjamin Walker), and Franklin Sousley (Joseph Cross), are all remembered by the three surviving flag raisers, intercut with the men's ascent up the fake Mount Suribachi. Ira recalls Strank's last push to destroy Japan's stronghold of the island, and Doc remembers Harlon's last breaths as he cradles his lifeless body. These moments may appear to counteract the film's criticisms of war photography and what the Rosenthal image failed to represent since these moments resort

\footnotetext{
${ }^{53}$ J. David Slocum, "General Introduction: Seeing Through American War Cinema," 16.
} 
to the idea that war is essentially about lost brothers. However, later scenes complicate notions of male camaraderie that are evident earlier in the film.

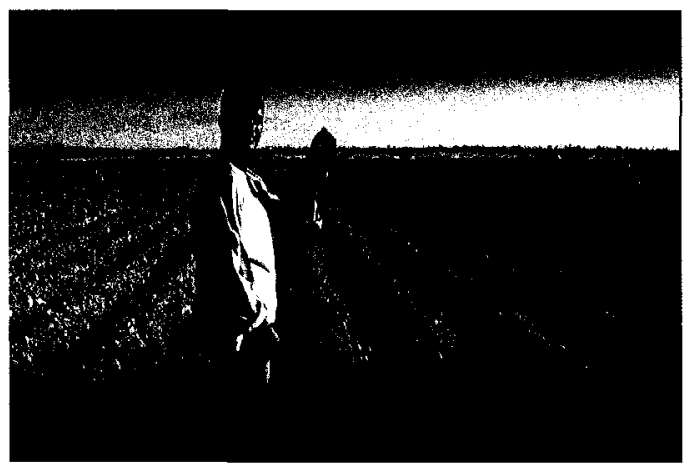

Figure 2.18 Flags of Our Fathers
As I have suggested in the last paragraph, the film poses the problems that are associated with the construction of heroism around the flag raisers. Near the film's end with the unveiling of the war memorial with all three surviving men in attendance, the question of their heroism

remains unresolved. Back in the present, Doc's son remembers being advised when it got close to Memorial Day to tell reporters that his father was not present to speak to them. Followed by Ira's speech in front of fellow Indians at the National Congress of American Indians, Ira focuses on his audience with a deadpan stare and explains that, "Because of the war, white men will understand Indians a lot better." This instance is followed by a white family pulling over to get their picture taken with Ira, working in a dusty field with a group of other Indian farm hands. The father asks Ira, “you're the hero right?" Ira makes a subtle gesture of pulling out a worn out American flag from his pocket, accompanied with a slight grin. Braudy insists, "both [Flags of Our Fathers and Letters From Iwo Jima] anatomize national heroic fantasies. "54 Flags of Our Fathers drains the Rosenthal photograph of its patriotic and nationalistic meaning and instead, portrays the

\footnotetext{
${ }^{54}$ Braudy, "Flags of Our Fathers/Letters From Iwo Jima," 19.
} 
individual hardship, suffering, and disillusionment of the Iwo Jima soldiers that America eventually turned a blind eye to.

In this chapter, I have worked towards establishing an argument that would suggest how realism developed in war photography to promote an idealized and preferred notion of photographic "truth", often reinforcing timely nationalist political ideologies. I have followed up on this notion and how war films like Saving Private Ryan and Flags of Our Fathers have utilized war photography realism to either authenticate or complicate their depiction of the war experience. Flags of Our Fathers embodies a major shift in war cinema in the post-9/11 context through the film's resistance to simply reproduce the myths associated with the realist aesthetics found in early war photography. In the next section, I will analyze the logistics of electronic video and how digital filmmaking is being used to make war films in a new era, often appropriating the aesthetics of war realism found in early war photography to forge a kind of new media amateurism, creating new ways of seeing and transmitting the war experience. 


\section{CHAPTER TWO}

\section{Digital Ways of Seeing}

"The first casualty when war comes," said Senator Hiram Johnson in 1917, "is truth." Senator Johnson was only half right. Governments at war use the truth whenever it serves their purposes: it is ambiguity which they find intolerable.

George H. Roeder, Jr., War as a Way of Seeing

In other words, can't we say that to give an example, to instantiate, to be concrete, are all examples of the magic of mimesis wherein the replication, the copy, acquires the power of the represented? And does not the magical power of this embodying inhere in the fact that in reading such examples we are thereby lifted out of ourselves into those images?

Michael Taussig, Mimesis and Alterity: A Particular History of the Senses

I am the Cine-Eye. I am a mechanical eye. I, a machine, show you the world only as I can see it. $^{55}$

\section{Dziga Vertov in Graham Roberts, The Man with the Movie Camera: The Film Companion}

In the last chapter, I examined how early war photography established a standard of war realism that has informed the aesthetic of the fictional war film. This chapter will examine a new era of war images that includes the digital transformation of photography and film, enabling the production and circulation of much more non-professional imagery. This new era of image making involves 'amateur' ways of producing and disseminating information that bypasses professional structures of media production, distribution and circulation. Electronic images are increasingly produced and disseminated by 'amateur' photographers - soldiers who are recording their own war experience with new digital devices, such as camera-phones, and MiniDV cameras. These consumer-grade devices have not only allowed less-professional photographers/cinematographers to represent

\footnotetext{
${ }^{55}$ Graham Roberts reproduces this section of a passage from an unpublished book written by Dziga Vertov called, "The Cine Eyes. A Revolution." See Graham Roberts, The Man with the Movie Camera: The Film
} 
more candid and intimate images of their experiences of events, but they have also created new ways to circulate and transmit images via new media networks.

Three American films will be examined in this chapter: In the Valley of Elah, The War Tapes, and Occupation: Dreamland. The latter two films are documentaries, whereas In the Valley of Elah is a fictionalized drama inspired by real events. I will be looking at both fictional and documentary war films in this chapter because both modes of filmmaking are concerned with digital screen culture and how the war in Iraq is mediated through digital aesthetics. These films will be analyzed with close attention to how digital video is being utilized by American soldiers to document and transmit a plethora of opinions, testimonials, and attitudes towards the war in Iraq.

In the Valley of Elah features both digital video imagery and $35 \mathrm{~mm}$ film. The digital imagery in the film exists diegetically in the form of camera-phone videos shot by Mike Deerfield (Jonathan Tucker), an American soldier, to document his traumatic war experience in Iraq. The $35 \mathrm{~mm}$ format exists non-diegetically as the medium for which the spectator has access to the film's narrative. Mike's videos are later viewed by his father, Hank Deerfield (Tommy Lee Jones), as Hank investigates the death of his son, hoping to uncover why he was brutally murdered. The film's narrative that largely consists of Hank's investigation is often disrupted by Mike's war experience caught on digital video. The videos facilitate a psychological connection between both individuals through technology. The relationship developed between Hank and Mike is what Ned Schantz calls "telephonic". Schantz states that "the phone accommodates an old and deep cinematic desire to be in two or more places at once, to transcend the limits of our 
individuality." I ${ }^{56}$ would also add that this technology, in its latest manifestation as the camera-phone, propagates a desire to transcend the limits of time. The videos allow Mike, even after his death, to share his traumatic experiences with Hank. The camera-phone facilitates this telephonic relationship, connecting the two on an emotional level, but distancing them spatially and temporally. The camera-phone videos in In the Valley of Elah juxtapose the film's present with the past (seen through digital), contrasting and contradicting what Mike's comrades say about Mike's role in Iraq with what Hank has seen in the videos. These videos capture snapshots of Mike's traumatic war experience, altering Hank's own perceptions of the American military and foreign policy. This solidifies the idea that the 'real,' 'on-the-ground' and spectatorial experience of war is mediated.

The documentary film, The War Tapes, is also about the mediated quality of both our and the soldiers' experience of the war. The War Tapes consists of 'amateur' footage shot by US soldiers in Iraq, blurring the distinctions between filmmaker and film subject. Various members of the New Hampshire National Guard's $172^{\text {nd }}$ Infantry Regiment, C Company, were given MiniDV camcorders to record their encounters during their tour of duty and their return home. The film creates a highly subjective account of their experiences through the simulation of a First Person Shooter (FPS) video game aesthetic. Interestingly, the film uses another medium's specific aesthetics to intensify the immediacy of a soldier's 'on-the-ground' experience. The War Tapes confounds the aesthetic differences between video games and cinema, and also between fiction and

\footnotetext{
${ }^{56}$ Ned Schantz, "Telephonic Film," Film Quarterly (Summer 2003), 23.
} 
documentary film. The film's mixture of fiction and non-fiction codes and conventions, combined with a variety of soldier testimonies, gives viewers a multitude of candid perspectives into the conflict, ultimately complicating the narrative of the war in Iraq.

The last film analyzed in this chapter is Occupation: Dreamland. Through the conflicting testimony of soldiers, evening patrols shot through night-vision cameras, and deteriorating communication between US soldiers and Iraqi civilians, Ian Olds and Garrett Scott construct a film of human alienation. This produces a narrative structural logic that the filmmakers identify as a dialectic between "escalation and frustration," as stated in the DVD's audio commentary. Like The War Tapes, Occupation: Dreamland consists of fragmented, often contradictory, and inconclusive information, again, unable to offer a clear rationalization of what it means to be over there.

\section{I: David Versus Goliath: Trauma, Truth and In the Valley of Elah}

Having served as a screenwriter on Eastwood's Flags of Our Fathers and Letters From Iwo Jima, Paul Haggis returns to similar themes in his production of In the Valley of Elah. The film narrows in on the depiction of PTSD (Post-Traumatic Stress Disorder), common in the American war film. PTSD is what was once referred to as "shellshock", a diagnosis of severe psychological trauma experienced by those returning from war. PTSD is often associated with veterans of WWII, Vietnam, the First Gulf War, and now, with soldiers returning from the current war in Iraq. This disorder is central to Hank's investigation into the causes of his son's brutal murder. It is hinted near the film's end that Mike's murder was a substance-induced accident, a fatal consequence of PTSD suffered by Mike and his close comrades. Mike's murderer and close friend, Corporal 
Steve Penning (Wes Chatham), explains that the incident could have easily happened to him. Penning tells Hank: "I think on another night that would have been Mike with a knife and me in the field."

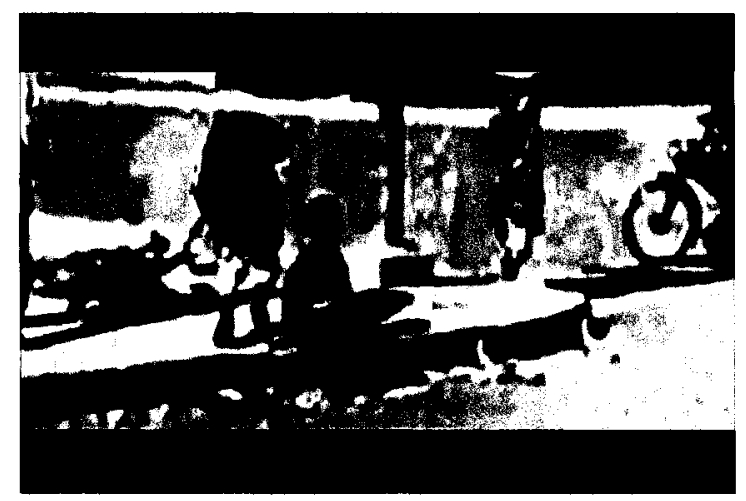

Figure 3.1 In the Valley of Elah (Paul Haggis, 2007)

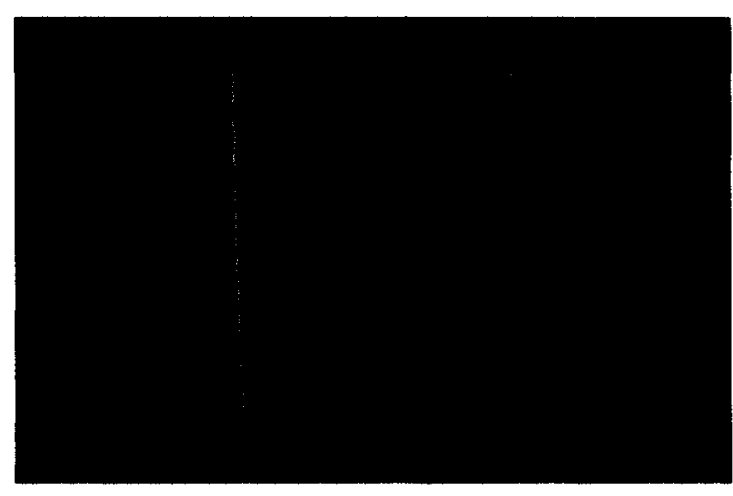

Figure 3.3 In the Valley of Elah

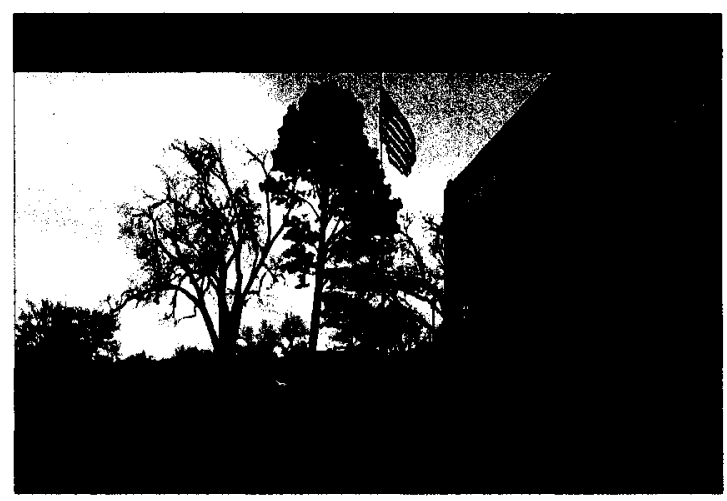

Figure 3.2 In the Valley of Elah

A part of Hank's investigation involves the recovery of digital videos that he discovers on his son's camera phone. The film opens with a voice-over of a man telling Mike to "[g]et the fuck back in the vehicle," accompanied by a low-resolution digital

image of a boy sitting on a street curb (Figure 3.1). At this point in the film, the narrative significance of the video is unknown. Hank makes his way to the military base where Mike had been stationed before his disappearance, and comes upon an upside-down American flag waving on the front lawn of a school (Figure 3.2). Hank stops and explains to the "flag raiser" (the school's custodian) that this is a distress signal suggesting that "America is in real trouble," and proceeds to turn the flag right side up. A similar 
scene appears at the end of the film - Hank returns to the school, this time with a tattered, worn out flag Mike had sent him from overseas. Hank decides to have this one raised up the pole instead of the original, this time, back to its initial position, confirming the film's initial metaphorical suggestion (Figure 3.3).

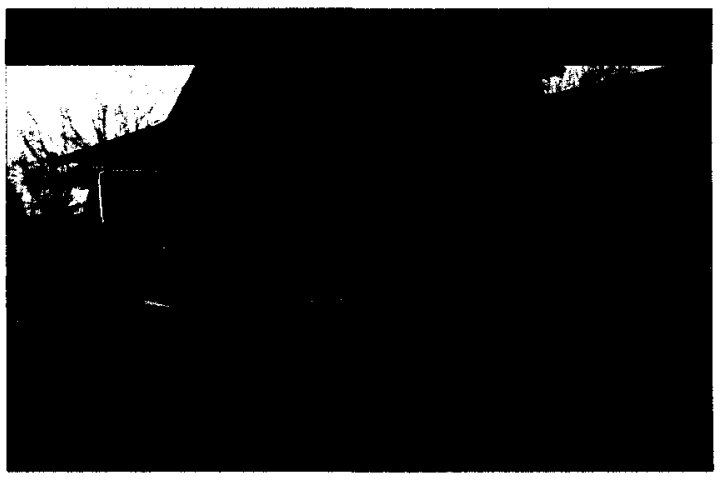

Figure 3.4 In the Valley of Elah
The meaning of the American flag in Flags of Our Fathers and In the Valley of Elah changes throughout both films. ${ }^{57}$ Both use the flag to suggest that America is a nation in distress. The iconic status of the American flag is recognizable in the first flag raising and is a symbolic extension of Hank's

patriotism, reinforced by the American flag that waves in the "correct" position at the front of his house near the start of the film (Figure 3.4). However, the flag loses its patriotic meaning in its second appearance, since it is not really the same flag when the placements of the stars and stripes have been "rearranged". The change in the flag's positioning alludes to Hank's own transformation from an ideal American citizen (since he was also once in the military) to a skeptic by the film's end. When he first hears that Mike has gone AWOL (Absent Without Official Leave), he explains to Mike's mother (Susan Sarandon) that "he's probably held up some place celebrating." This is certainly not the case when Mike's parents learn of the abundance of stab wounds and

\footnotetext{
${ }^{57}$ Rosenthal's image captured the second time the men on the top of Mount Suribachi raised the American flag for the purpose of being photographed. Rosenthal missed the first raising.
} 
dismemberment that Mike's body suffered upon his death. Like the flag, Hank's world had been turned upside down.

The camera phone videos both establish connections and maintain distances between characters, most significantly between Hank and Mike. Despite the visual emphasis accorded to the video and photo capabilities of the camera phone, its roots in telephone technology should not be overlooked. According to Tom Gunning, "with new technological topologies confronting us, $\ldots$... we [must] look back at the first experiences of technology with an uncanny sense of déjà vu." Over the Phone: The Lonely Villa and the de Lorde Tradition of the Terrors of Technology," that the inclusion of the telephone in early cinema radically changed narrative film editing, allowing filmmakers like D.W. Griffith to formulate new editing techniques like parallel editing - the conjoining of two disparate geographic spaces together by alternating shots of separate locations to suggest simultaneous action. An important point made by Gunning is that the telephone was used in early narrative cinema to increase the tension between the helpless parties on either end of the line.

In The Lonely Villa, a father listens over the phone attentively to his wife's cries of help as their house is being invaded by a group of burglars. Griffith's film alternates between shots of the father on the telephone at a nearby hotel with shots of the wife at home. The telephone enables the father in the film to remotely witness events happening at his home estate, while being rendered powerless and impotent to physically intervene. Gunning states:

\footnotetext{
${ }^{58}$ Tom Gunning, "Heard Over the Phone: The Lonely Villa and the de Lorde tradition of the Terrors of Technology," in Screen 32:2 (Summer 1991); 185. his emphasis.
} 
Technology functions, as Freud indicated, as a more than mixed blessing; it becomes a system of connections and separations, of distances and proximities, or appearances and disappearances, in fact a sort of titanic game of fort/da, by which modernity manages its fear of loss by tying it to a secondary anxiety that of being cut off. ${ }^{59}$

The fear "of being cut off" is realized when the burglars decide to cut the main phone line that connects the home, causing what Gunning says is "the greatest panic in the film." Technology can be a tool of great advantage and service in solving problems to do with space by connecting individuals in separate locations. However, it can also be fragile and susceptible to complete breakdown, as is the case in The Lonely Villa. The camera-phone in In the Valley of Elah functions in the same way that the phone operates in The Lonely Villa. The videos in the film allow Hank to witness Mike's traumatic experiences in Iraq, but also render him helpless since Hank is distanced from Mike's trauma spatially and temporally.

Mike's videos depict his deranged behaviour in Iraq, presenting a psychologically unstable soldier. These videos contradict claims made about Mike's heroism stated by his comrades. These camera phone images give the impression of spontaneity and randomness, that they are somehow more "truthful" than other types of photographic images. Gerard Goggin argues that there is an important distinction in the everyday applications of the camera-phone versus the special occasion usage of conventional stand-alone cameras. Goggin quotes a study conducted by a pair of Japanese media scholars who state:

Within the broader ecology of personal record-keeping, archiving and communication technologies, camera phones occupy a unique niche. In

\footnotetext{
${ }^{59}$ Ibid., 195.

${ }^{60}$ Ibid., 193.
} 
comparison to the traditional camera, which gets trotted out for special excursions and events - noteworthy moments bracketed off from the mundane - camera phones capture the more fleeting and unexpected moments of surprise... in the everyday. ${ }^{61}$

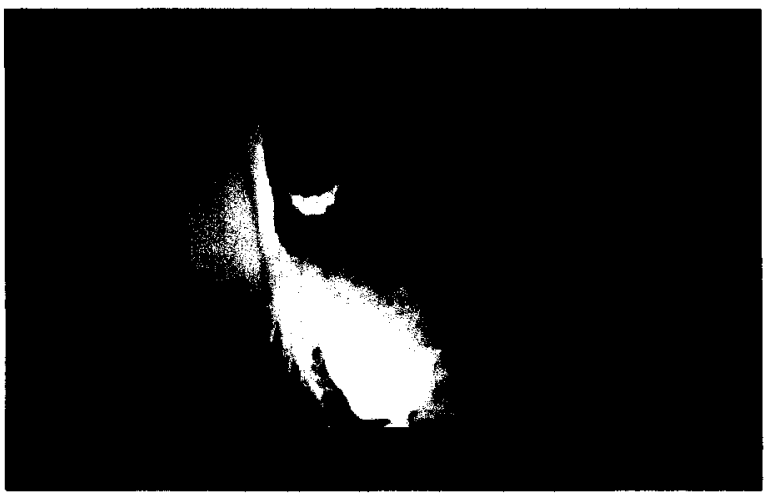

Figure 3.5 In the Valley of Elah
Mike's digital images would then be considered to be the kinds of "everyday" images that Goggin discusses, and thus, a more honest intervention in the production of war images. There are many instances where Mike's comrades reminisce about the bravery and heroism that Mike displayed throughout

their time in Iraq. Specialist Gordon Bonner (Jake McLaughlin) tells Hank that "he was a first class soldier," and that the army "shouldn't send heroes [like Mike] to places like Iraq." Upon his confession, Penning adds, "I think [Mike] was the smart one." Hank's proximity to Mike's war experience is mediated through technology, foregrounding the fact that Hank can never fully understand or feel what his son had suffered. One video presents a night raid when Mike encounters the lifeless bodies of various civilian casualties. Mike, documenting his own perspective of events, proceeds to place a flaming head sticker on the forehead of one of the house's bodies, demonizing the unidentifiable victim (Figure 3.5). In another video, Hank witnesses the madness surrounding the incarceration of an injured terrorist suspect. On the floor in the rear of a Humvee, Mike's squad members cackle as Mike places his finger inside a flesh wound of the captured man

${ }^{61}$ Gerard Goggin, Cell Phone Culture: Mobile Technology in Everyday Life, (New York: Routledge, 2006); 145. 
and asks, "Where does it hurt?," as the man screams in agony. These scenes of sadistic behaviour contradict claims of Mike's heroism. Mike's digital past contradicts how he is rememberd in the film's present, complicating his commemoration as an undisputed "war hero."

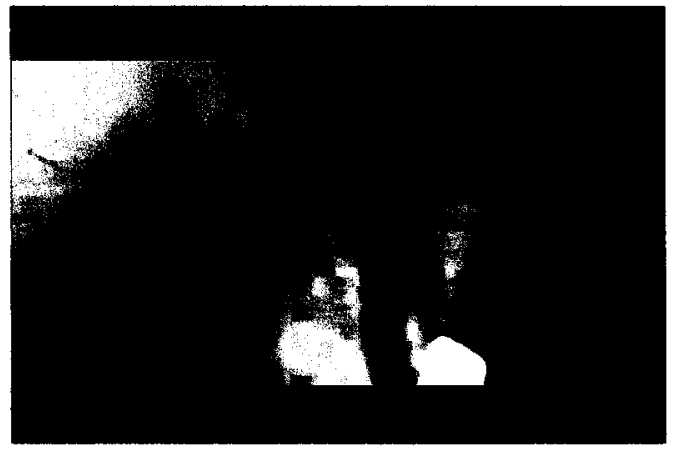

Figure 3.6 In the Valley of Elah

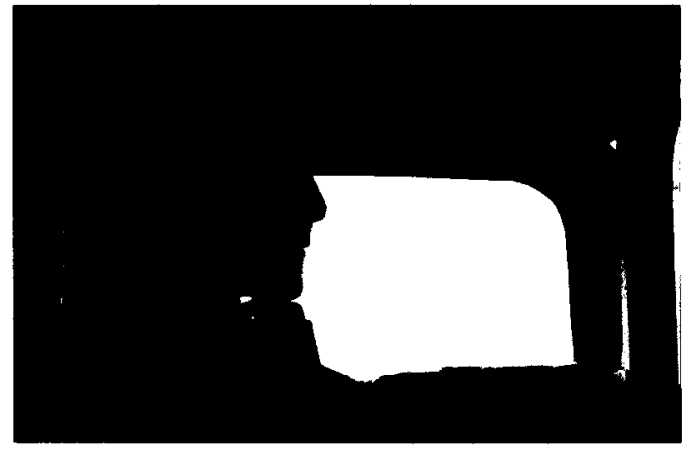

Figure 3.7 In the Valley of Elah

The question of Mike's heroism is further problematized by Hank's viewing of a video that depicts Mike's failure to stop for a boy who was blocking the path of their moving convoy. Seen early in the film as a digital video, Mike is told by an off-screen voice to "not stop," thereby running the child over (Figure 3.6). The video's frame suddenly jerks, suggesting that Mike obeyed his orders and did, in fact, run over the boy. Later in the film, the incident is repeated, this time on film through Hank's perspective, imagining what may have happened. Mike's presence in the film is viewed exclusively through video, up until Hank's vision of the event, which is now viewed through film (Figure 3.7). In the Valley of Elah shifts between these two formats when narrative perspectives alternate between Mike and Hank, disrupting the seamless narrative flow of the film, and a common documentary strategy. Susan L. Carruthers explains that multiple narrative perspectives are frequently used in Iraq war documentaries - "[T]hese films defy 
ready categorization." She argues that the films "tread a fine line between observation and participation, between assuming a position and taking a stand," and adds that in these documentaries, "[p]erspective is purposely fractured." "62 Similarly, In the Valley of Elah fractures the singularity of its narration by telling the story through both film and digital video, assuming a dual perspective.

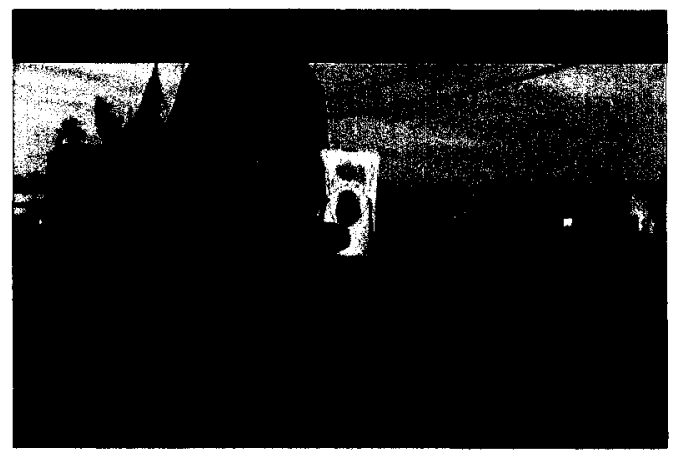

Figure 3.8 In the Valley of Elah

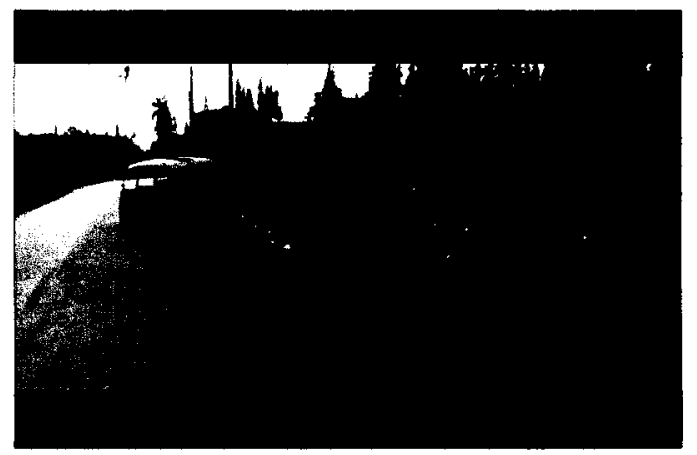

Figure 3.9 In the Valley of Elah

Greater coverage of the event is granted in Hank's mental vision through the use of omniscient camera angles that are not tied to any on-camera subject. Mike is now seen stopping and exiting the vehicle shortly after hitting the boy, staring blankly at the result of his actions. Mike directs his cell phone at the site of the incident and takes a snapshot, supposedly the image that appears on Hank's laptop in earlier scenes (Figure $\mathbf{3 . 8}$ and Figure 3.9). Geoffrey Klingsporn notes that since the use of photography in recording WWI, "war can no longer be distinguished from its mediation."63 Mike's compulsion to photograph the moment confirms the inextricable nature of war and images, but also of

\footnotetext{
${ }^{62}$ Susan L. Carruthers, "Say Cheese!: Operation Iraqi Freedom on Film," in Cineaste 32:1 (Winter 2006); $31,32$.

${ }^{63}$ Geoffrey Klingsporn, "War, Film, History: American Images of 'Real War,' 1890-1920," in Hollywood and War: The Film Reader, ed. J. David Slocum, 33 (New York: Routledge, 2006).
} 
the human body and technology, echoing Marshall McLuhan's concept of technology as an extension of the human body. Goggin argues that the cell phone has the status of " "a prosthetic' object," and hence is, " "part of its owner'."64 This kind of mediated vision is also described by Susan Sontag, who, as Goggin has noted, argues that "photographs have produced a new practice of mediate vision - 'looking with photographs'."65 Mike's decision to photograph this moment isolates the event from its unique time and place within the historical world, allowing Mike's trauma to exist in the form of an image, later shared with Hank. B. Scifo explains that:

[T] he camera-phone is not only an increasingly personal technology (being deeply set within the subject, his or her universe and relationships) but also a collective technology, a resource for 'face-to-face' sociality, entertainment and communicative exchanges within contexts of local interaction and principally within a group of peers. ${ }^{66}$

Camera phone images can be transmitted and shared between members of an exclusive group at the user's discretion. In the case of In the Valley of Elah, the event is memorialized as an electronic file, an object that can be revisited by Mike and, presumably, by others.

André Loiselle describes the function of historical trauma in the cinema of Canadian filmmaker, Michel Brault, which is equally applicable to In the Valley of Elah "The only way for the divided self to deal with trauma, it has been argued, is to share the

\footnotetext{
${ }^{64}$ Goggin, Cell Phone Culture: Mobile Technology in Everyday Life, 46.

${ }^{65}$ Ibid., 152.

${ }^{66} \mathrm{~B}$. Scifo, "The domestication of the camera phone and MMS communications: the experience of young Italians," in A Sense of Place: The Global and the Local in Mobile Communication, ed. K. Nyíri, 367, (Vienna: Passagen Verlag, 2005).
} 
experience through a process of historiography., ${ }^{, 67}$ Ruth Leys' work on trauma in her book, Trauma: A Genealogy, discusses the logistics of working through trauma by representing it: "the experience of the trauma, fixed or frozen in time, refuses to be represented as past, but is perpetually reexperienced in a painful, dissociated, traumatic present." ${ }^{, 68}$ Mike's photograph historicizes the event by preserving it in an image, being refused the chance to forget what had happened. "History, like trauma," Cathy Caruth argues in her book, Unclaimed Experience Trauma, Narrative and History, "is never simply one's own, $[\ldots]$ history is precisely the way we are implicated in each other's traumas. ${ }^{, 69}$ In the film, the photograph functions as a guard against forgetting the event. It is used as a form of catharsis and remembered as a moment of confrontation between personal morality and military objectives.

The electronic images in In the Valley of Elah highlight the fact that soldiers in Iraq are disseminating and circulating their own images of war to the home front outside of conventional media structures. Attached with a whole host of meanings and notions of authenticity, these less-professional images are often said to be more truthful and honest depictions of the reality that the image frames. But images require contextualization, as we have seen in Chapter One. On their own, they do not really tell us anything, but this is not to suggest that images are no longer important. For instance, the Abu Ghraib prison scandal photographs signify the on-going narrative power of digital images and their

\footnotetext{
${ }^{67}$ André Loiselle, "Double-Telling: Narratives of Traumatic History and Québec's Two 'Terrorist Crises' in the Films of Michel Brault," paper presented at the Hawaii International Conference on Arts and Humanities. Honolulu. January 2003.

${ }^{68}$ Ruth Leys, Trauma: A Genealogy, (Chicago: University of Chicago Press, 2000); 2.

${ }^{69}$ Cathy Caruth, Unclaimed Experience Trauma, Narrative and History, (Baltimore: John Hopkins University Press, 1996), 24.
} 
influence on forming public opinions of the war in Iraq and on American foreign policy. These images have been interpreted in multiple ways and been given different narrative explanations by both US military officials and by those depicted within them. The state and media controversy and contest over the meaning of the photographs was a reminder that images can mean different things to different people. Military and state officials like then Secretary of Defense Donald Rumsfeld, felt that the images documented the actions of "a few bad apples," and did not represent what was being accomplished in Iraq.

However, former-Specialist Sabrina Harman has said that she and her fellow officers were only following orders, suggesting that there was an official policy of torture and coercion. In the Valley of Elah demonstrates that even seemingly "everyday" digital images have their narrative limitations, and can still keep us at a temporal and spatial distance to events captured with the photographic frame. Similar issues concerning the 'amateur' depiction of the war in Iraq are also evident in the documentaries that will be discussed throughout the remainder of this chapter.

\section{II: The "Automation of Sight" and The War Tapes}

The War Tapes supposedly features "amateur" footage. However, the "amateur" aesthetics featured in the film are deeply informed by the aesthetic and stylistic qualities of other fictional films - and other media, such as video games. The strategy of visualizing the war by American soldiers in The War Tapes is often structured around a first-person shooter (FPS) video game aesthetic. Selected American soldiers were given 


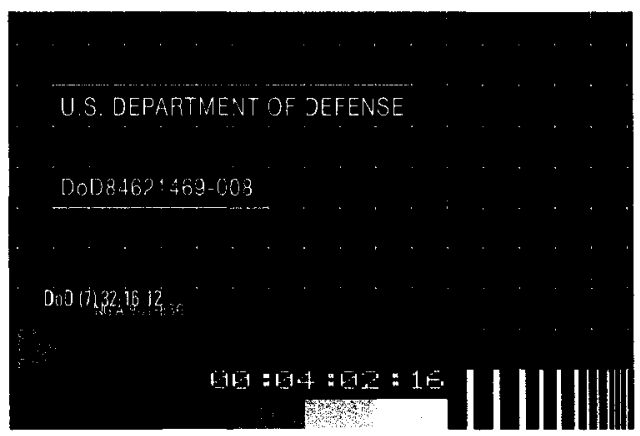

Figure 3.10 Cloverfield (Matt Reeves, 2008)

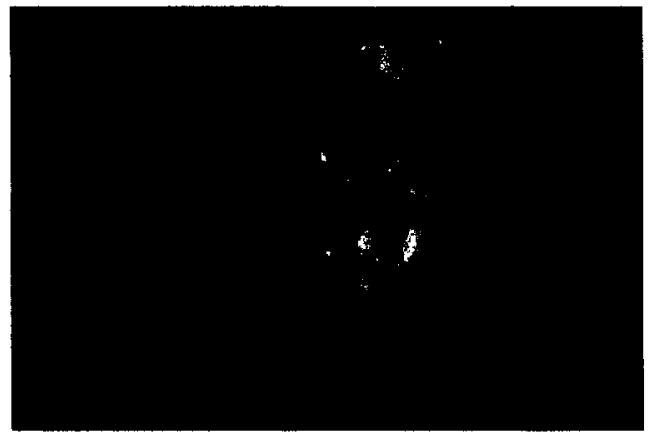

Figure 3.11 Cloverfield

the opportunity to record their own experiences in Iraq with digital camcorders for Deborah Scranton's documentary, positioning them as "amateur auteurs" in charge of recording footage for the film that would inevitably exhibit their captured images. ${ }^{70}$ New developments in consumer camera technology have become the grounds for new ways to envision some of Hollywood's most popular genres. Recent films like Cloverfield (Matt Reeves, 2008) and Diary of the Dead (George A. Romero, 2007) play with the conventions of the horror film genre (monster/zombie) by introducing the novelty of amateur digital filmmaking to their narratives. In both films, young adults are compelled to record their terrifying encounters with monsters (a sea creature the size of the Empire State Building in the former and the living dead in the latter) with their digital camcorders. The opening of Cloverfield presents an NTSC colour bars screen with a running timecode that displays the heading, "US Department of Defense," suggesting the fact that the cinema-verité style imagery to follow is a unique and privileged view into the film's shocking narrative events (Figure 3.10 and Figure 3.11). Likewise, in Diary of the Dead,

\footnotetext{
${ }^{70}$ Carruthers, "Say Cheese!: Operation Iraqi Freedom on Film," 32.
} 
student filmmakers encounter real-life zombies during the production of their low-budget mummy movie and opt to record the invasion instead.

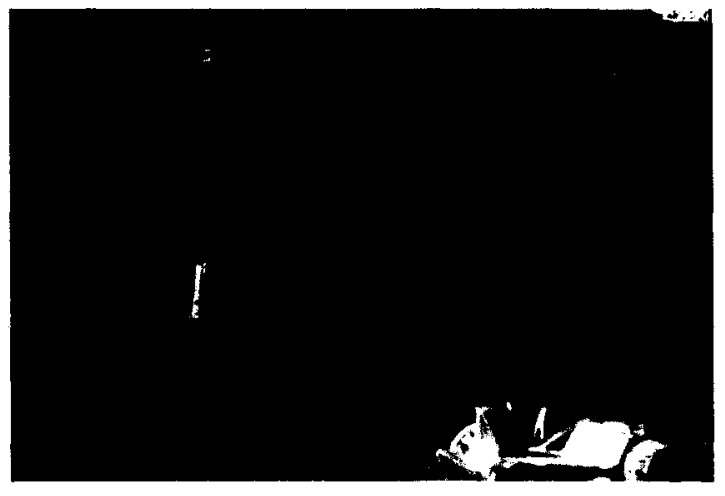

Figure 3.12 The War Tapes (Deborah Scranton, 2006)

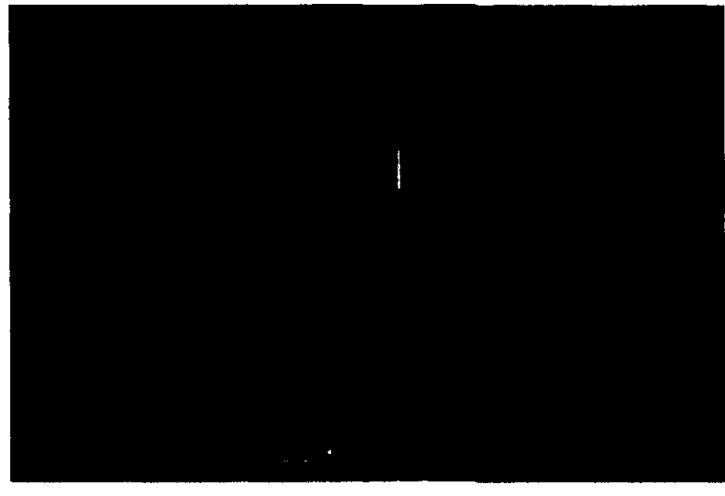

Figure 3.13 Doom (Andrzej Bartkowaik, 2005)

In her famous essay, "A Cyborg Manifesto," Donna Haraway claims that "the boundary between science fiction and social reality is an optical illusion." ${ }^{, 11}$ In The War Tapes, the boundary between the 'real' and simulated war experience becomes equally indistinguishable. The recorded reality of the war experience in the film is often depicted through shots that mirror the aesthetics of FPS video games (Figure 3.12). Over images of an exchange of firepower between US soldiers and a hidden enemy, Steve Pink, an American soldier, says, "I want to kill. ...I have a reoccurring epiphany. This is happening and will have a lasting impact on me for the rest of my life." The heightened sense of danger and immediacy of this event is further reinforced through sounds of raw firepower heard off-screen and through the use of jerky, hand-held camera movements that simulate an FPS aesthetic. These FPS shots in The War Tapes are characterized by shaky camera movements that include the appearance of a gun barrel peeking out of the

\footnotetext{
${ }^{71}$ Donna Haraway, "A Cyborg Manifesto," in The Cybercultures Reader, ed. David Bell and Barbara M. Kennedy, 291, (New York: Routledge, 2000).
} 
lower right-hand corner of the camera's frame - as if mounted directly on top of the rifle's barrel. Patricia R. Zimmerman has described the relationship between military and cinematic vision. "The conflation between camera's and guns," Zimmerman claims, "strengthened when cameras were inserted on machine gun mounts in bomber planes and operated by pilots [in WWII]."72 In The War Tapes, digital camcorders are mounted on the barrels of rifles so that viewers are given shots and angles that are dictated by the direction of the soldier's weapon.

The collapse of videogames and cinema can be most obviously seen in the Doom franchise where the FPS aesthetic used for the videogame is simulated in Andrzej Bartkowaik's film adaptation of the game in 2005 (Figure 3.13). Alexander R. Galloway suggests that, in recent years, video games and cinema have developed a close and interconnected relationship. Galloway states:

Today video games and film are influencing and incorporating each other in novel ways. Through a historical transformation that he calls the 'automation of sight,' Lev Manovich writes how the camera has adopted a more and more machinic gaze with the passage into the digital. ${ }^{73}$

The War Tapes blurs the boundaries between cinema and video games, often adopting a "machinic gaze" evident in other entertainment media. Viewers are not witnessing "amateur" footage but are in fact, seeing through highly codified visual aesthetics.

The War Tapes is certainly not the first war documentary that has incorporated the characteristic iconography of another medium or another genre. Zimmerman explains that

\footnotetext{
${ }^{72}$ Zimmerman, Reel Families: A Social History of Amateur Film, 105.

${ }^{73}$ Alexander R. Galloway, Gaming: Essays On Algorithmic Culture, (University of Minnesota Press, 2006), 39-40.
} 
“[r]ather than mirroring an unmediated 'reality,' military [documentaries] and even some combat films [from WWII] conversely [sought to achieve] Hollywood narrative style.,774 The FPS aesthetic in the film connotes a series of implications in terms of its subjective "look" and its simulation of human vision. Galloway recognizes that video games weren't the first medium to revel in this highly-subjective "look," but that this was actually born out of cinema first, later to be adopted by video games. In cinema, Galloway explains, "[o]ccasionally, two of the looks - the look of the camera and the look of a single character - merge together, so that the camera lens and the eyes of a character become one."75 Aligning the "look" of the film camera with narrative characters can be seen in the SQUID vision sequences in Strange Days (Kathryn Bigelow, 1995) or when characters temporarily inhabit the body of John Malkovich in Being John Malkovich (Spike Jonze, 1999). ${ }^{76}$ The FPS shot imitates a human look, the shakiness of the image coinciding with the physiological implications of seeing in a constantly moving body, resisting more regimented camera movements that evoke a disembodied gaze, typically achieved through the use of dolly and tracking shots that seem to glide through diegetic space.

In a scene that parallels Mike's incident in In the Valley of Elah, Specialist Jon

\footnotetext{
${ }^{74}$ Zimmerman, Reel Families: A Social History of Amateur Film, 94.

${ }^{75}$ Ibid., 41.

${ }^{76}$ In Strange Days, characters buy illegal virtual reality devices known as SQUID to experience other people's more exciting and stimulating life encounters that range from sex, robbery, and murder. These SQUID devices play recorded memories, enabling one to imagine what it would be like to be someone else. The opening sequence of the film depicts the use of the SQUID device replaying a failed robbery without the narrative context of the technology being revealed to viewers, collapsing the "look" of the camera, narrative character, and spectator into one unifying ocular gaze. These shots adopt a similar shaky, handheld camera aesthetic utilized in The War Tapes. In Being John Malkovich, a secret portal launches those that enter its divine realm into the body of John Malkovich, who also happens to play himself in the film. These instances of looking through the eyes of John Malkovich are framed by two small aperture-like openings that give the impression of looking through a face mask, reminding viewers of the artifice of their sutured gaze.
} 
Baril, a member of Pink's New Hampshire unit, recalls an event that his comrade, Mike Moriarity, was able to document. Shot with Moriarity's camcorder, Baril explains, in retrospect (since the dialogue is presented in voice over), the damaging effects that an

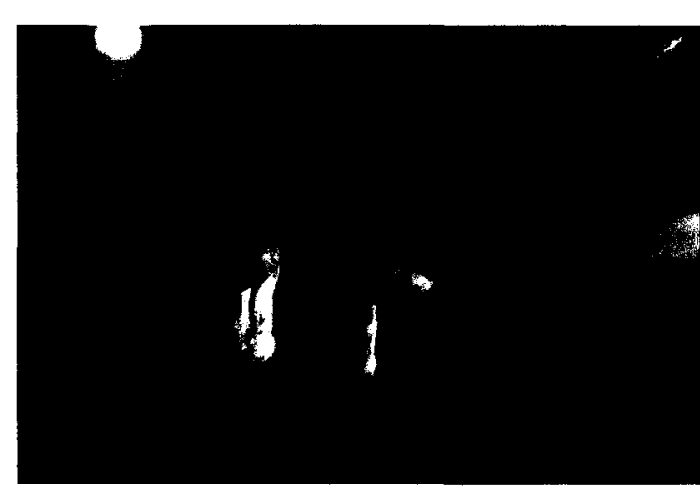

Figure 3.14 The War Tapes accident involving a woman being run down by an American convoy will have on him for the rest of his life (Figure 3.14). As another example of a shared trauma, Baril attempts to make sense of the original incident by speaking over Moriarity's captured footage. Baril states: "She's in

pieces right now. She ran out in front of us. I remember looking down and I see crumbled cookies. I thought of my mother." His recollection lacks coherence - avoiding a simple explanation of how the event transpired. The images that accompany the voiceover evoke the aesthetics of war realism discussed in Chapter One, specifically Capa's DDay photographs, where an "amateur" and highly subjective point of view was relied upon to capture the chaotic experience of the landings. In The War Tapes, a subjective image aesthetic is being used, but in a way that highlights the difficulty of trying to retell one's lived trauma.

The trauma of the Iraq war in The War Tapes is conveyed through the film's adoption of a subjective camera gaze. Carruthers argues that The War Tapes, and the film I will discuss in the next section, Occupation: Dreamland, "tread a fine line between 
observation and participation, between assuming a position and taking a stand."77 The film's subjects in The War Tapes are at once catalysts and objects of the camera's gaze, constructing a film that falls between participatory and observational documentary cinema. The US soldiers depicted in The War Tapes are as much subject to the film's curious gaze as they are agents that control its point of view.

The complexity of the soldiers' role in the film is further reinforced by the various opinions that the film's subjects have concerning state and military policies. The film's narrative strategy encourages a variety of interpretations and understandings of the Iraq war experience. Zimmerman argues that digital Iraq war documentaries fragment rather than totalize narrative testimonies and represent a recent shift in how visual histories are being told and constructed:

[T] he philosophy of history [has] moved history away from a single metanarrative and an omniscient viewpoint based on referentiality, realism, and facts that repress heterogeneity. It now moves towards a more particularized, multicultural construct of plural pasts. [Robert F.] Berkhofer [Jr.] terms the structure of these plural pasts "polyvocalities," where more than one viewpoint is present and disjunctures abound, opening up historical analysis to different explanatory models. ${ }^{78}$

The War Tapes' polyvocality is manifested in the various accounts of the different soldiers testimonies that the film's viewer is given access to, representing a complex account of the war experience. Despite the film's more democratic approach to documenting events, the “amateur auteurs" were often given advice by the film's director, who suggested conventional camera techniques and practices. In an online interview with the film's

\footnotetext{
${ }^{77}$ Carruthers, "Say Cheese!: Operation Iraqi Freedom on Film," 31.

${ }^{78}$ Patricia R. Zimmerman, "Public Domains: Engaging Iraq Through Experimental Digitalities," in Framework 48:2 (Fall 2007); 71.
} 
director, Deborah Scranton, Wired magazine writer Jason Silverman states that Scranton "used e-mail and instant messaging to provide [soldiers] with advice on technique and technical issues," producing images that Scranton "considered thoughtful, [and] often beautifully shot." ${ }^{, 79}$ The editing stage of the film also played a major role in organizing what shots would and would not be included in the film's final cut. Steve James and Leslie Simmer, editors of The War Tapes, were largely in charge of deciding what to include in the film's final 97 minute runtime, with Scranton occasionally making the odd oral recommendation. James and Simmer constructed a feature-length film that left approximately 798 hours of raw footage on the cutting room floor.

The War Tapes reflects a carefully-constructed and polished product where specific types of images and recorded moments were obviously preferred for inclusion in the final cut of the film versus others that were deemed uninteresting for audiences, creating a mediated experience of Iraq filtered through the editing choices and shooting recommendations made by Scranton and her editors. Scranton has acknowledged that "[m]ost of the footage, including hours of road shots, was mundane. But with their cameras constantly rolling, the soldiers captured plenty of revealing and terrifying moments of the kind a drop-in journalist couldn't." ${ }^{, 80}$ Carruthers argues that even though the editing of these documentaries closely reflects the conventions of fictional narrative editing (notably, cause-effect), they do resist the conclusiveness of typical narrative endings. Carruthers states: "The tour of duty provides a rough narrative arc, albeit an

\footnotetext{
${ }^{79}$ Jason Silverman, "GIs Shoot Footage for New War Doc," Wired (April 28, 2006) http://www.wired.com/culture/lifestyle/news/2006/04/70749 (accessed March 7, 2008).

${ }^{80}$ Ibid.
} 
inconclusive one, given the pains of reintegration and prospects of redeployment...." 81

Several marines are given screen time that allow them to discuss topics such as morality, problems with the bureaucracy and, corporate politics associated with the "War on Terror" initiative. Early in the film, Pink explains that he felt "exploited and proud at the same time" after making it on a segment of CNN's nightly news. His feeling of doubt reflects the highly contested moral terrain of the war in Iraq that exists amongst members of his unit. Carruthers discusses the problematic meaning of the war in Iraq:

Three and a half years after the launch of Operation Iraqi Freedom, what do we call 'Iraq'? An occupation? War? Civil war? Insurgency? The definitional quagmire suggests the difficulties of parsing this matrix of internecine and transnational power struggles in accordance with the tripartite demands of linear narrative. ${ }^{82}$

This uncertainty of the American role in Iraq is matched by the uncertainty that many of the wives back home express about their husbands in the Middle East. Scenes of the homefront consistently interrupt the narrative flow of the events in Iraq, creating a narrative that navigates between two different experiences, that of the soldiers and that of their families. Moriarty's wife describes life after her husband was sent off to Iraq: "When Mike first went over there, we just told Matthew [(Mike's son)] that he was just going to go beat up the bad guys," and turns to her son and discusses the significance of the G.I. Joe doll his dad had given him - “[d]addy says that he has got all the stuff that he's got. Pretty cool, huh?" The idolization of Mike as a dignified and heroic fatherfigure is later called into question when one of Matthew's classmates expresses a different idea about what is happening over there. Moriarty's wife recalls what she had told

\footnotetext{
${ }^{81}$ Carruthers, "Say Cheese!: Operation Iraqi Freedom on Film," 32.

${ }^{82}$ Ibid., 31.
} 
Matthew: "You know people get killed over there." Moriarty later confesses, "I support the mission. If the problem is not going away then kick it up a notch. And I don't give a fuck if that means nuking this fucking country." This statement of jingoism contradicts the humanitarian aims of the war that the Bush administration and many other Marines advocate in the film as the main objective of the occupation. Bernd Huppauf states that the lack of moral clarity in recent war cinema is caused by the "final disappearance of the binary division between war films and anti-war films. ${ }^{, 83}$ Near the end of The War Tapes, Baril explains, "[t]he Iraqi people are who we are here to help.... It will be a better country in 20 years because we were there. I hope." This statement encompasses the film's overall ambivalence towards the legitimacy of the War in Iraq mission by not taking a clearly defined position on whether these soldiers are participating in a just war or not. The War Tapes, then, features more contradictions than it does conclusions.

\section{III: Seeing Through the "I's" of the Soldier: Occupation: Dreamland}

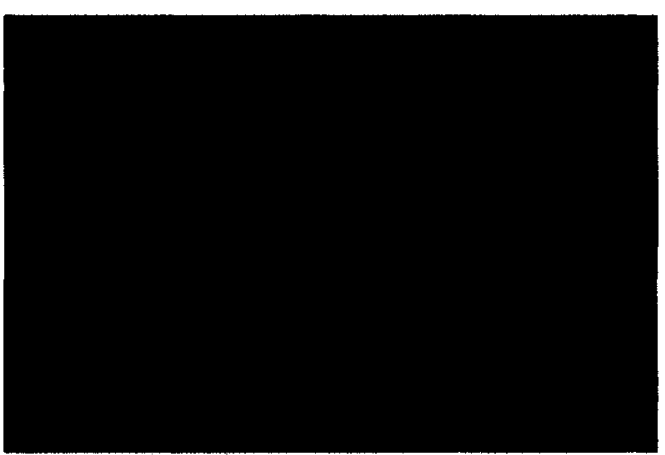

Figure 3.15 Occupation: Dreamland (Ian Olds and Garrett Scott, 2005)

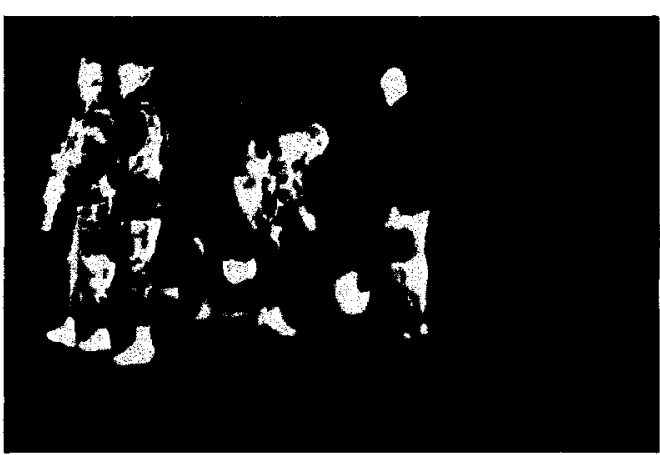

Figure 3.16 The War Tapes

\footnotetext{
${ }^{83}$ Bernd Huppauf, "Experiences of Modern Warfare and the Crisis of Representation," in Hollywood and War: The Film Reader, ed. J. David Slocum, 57, (New York: Routledge, 2006).
} 
Like The War Tapes, Occupation: Dreamland also depends on a highly subjective camera to bring viewers as close to the action as technically possible. The film documents events that lead up to the violence and crisis that erupted in the city of Fallujah in the Spring of 2004. The filmmakers embedded themselves with the 505 squad of the $82^{\text {nd }}$ Airborne Division, and experienced the same daily struggles and aggravations as the soldiers housed in what has been called "Camp Dreamland," a former vacation spot abandoned by Sadaam's high-ranking officers. The film's subjective camera is often created by allowing viewers to see through the "eyes" of its subjects, sometimes shooting in night-vision as other soldiers are depicted utilizing their night-vision goggles (Figure 3.15). Again, the distinctions between the camera's gaze and the subjects' gaze are broken down. For instance, in The War Tapes, thermal imagery is a recurring motif, displaying troops in a greenish negative image, appearing as ghostly apparitions within an alien environment (Figure 3.16). This trope is also seen regularly throughout the shortlived, thirteen-episode series, Over There (Steve Bochco and Chris Gerolmo, 2005), about a military units' first tour of duty in Iraq. In Occupation: Dreamland, Olds and Scott ensure viewers are constantly seeing the war as the soldiers $d o$ - through a technologically-mediated gaze. As J. David Slocum has argued: "To propose war as a way of seeing is ultimately to posit a way of subject-making and being in a world that has arguably changed with the conjoined evolutions of weaponry and cinema." ${ }^{\circ 4}$

\footnotetext{
${ }^{84}$ J. David Slocum, "War as a Way of Seeing," in Hollywood and War: The Film Reader, ed. J. David Slocum, 31, (New York: Routledge, 2006).
} 


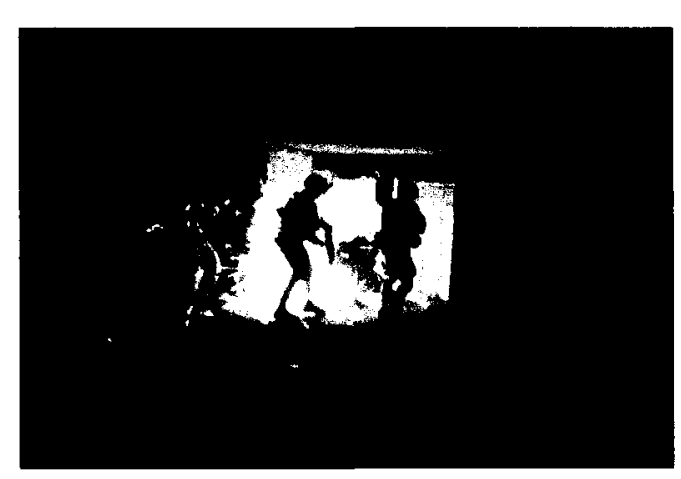

Figure 3.17 Occupation: Dreamland

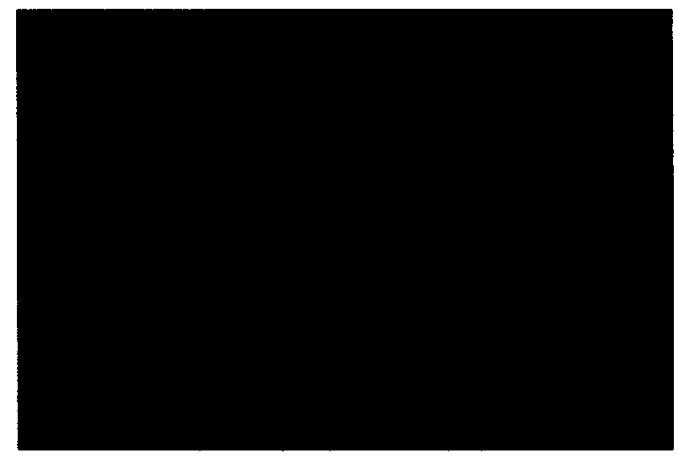

Figure 3.18 Occupation: Dreamland

An example of the conjoined evolutions of weaponry and cinema in the film is the presence of night-vision technology. The purpose of night-vision technology is to illuminate spaces that are too dark for the human eye to adequately perceive. In Occupation: Dreamland, night-vision is intended to allow soldiers and viewers to see in darkened spaces, twinning military ways of seeing with the viewers'. However, nightvision has also been said to have a reciprocal affect on its users, distorting reality, and dehumanizing those figures caught in its technological gaze. Kevin Robins explains the effect that night vision had in the first Gulf War, noting how soldiers often admitted that “Iraqi soldiers looked 'like ghostly sheep flushed from a pen'- bewildered and terrified, jarred from sleep and fleeing their bunkers under a hellish fire. One by one they were cut down by attackers they could not see." ${ }^{85}$ Carruthers recalls a similar effect that occurs in Occupation: Dreamland: "the business of breaking and entering - apprehended in night vision's phosphorescent green - assumes additional menace. Women and children cower in basements and backrooms, eerily irradiated. Alien figures, their cats-eyes pierce the

\footnotetext{
${ }^{85}$ Kevin Robins, Into the Image: Culture and Politics in the Field of Vision, (New York: Routledge, 1996); 65.
} 
dark." (Figure 3.17 and Figure 3.18) ${ }^{86}$ In the film, a subtitle reads: "Mission Objective: Detain suspected insurgents and search for rocket propelled grenades," after a group of US soldiers make their way through the home's front gates. The camera's night vision is utilized as soldiers kick through doors and enter the house. In the DVD's commentary, the filmmakers explain that during the filming of night missions, they would fix MiniDV cameras on their heads with a couple pieces of wood and gaffer tape to simulate a subjective ocular gaze. Shot within the estranging tones of night-vision, the squad questions the inhabitants, mothers with their terrified children, with the aid of a translator, trying to discover the whereabouts of their husbands. The soldiers leave empty-handed with little to no evidence of insurgent-related activity.

The soldiers' sense of alienation from the nation's inhabitants and surrounding environment is reinforced in scenes that depict troops interacting with locals. In one instance, a soldier initiates a friendly chat with a man standing outside of the gates of

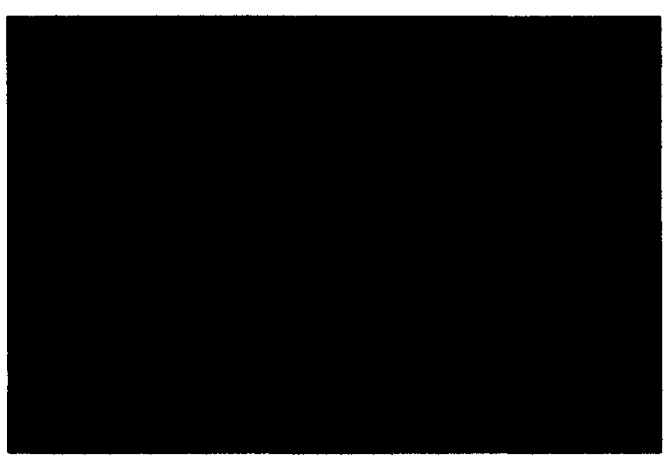

Figure 3.19 Occupation: Dreamland

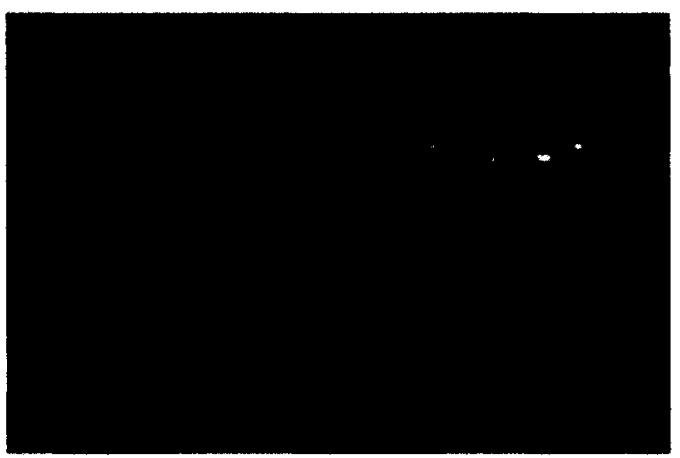

Figure 3.20 Occupation: Dreamland

${ }^{86}$ Carruthers, "Say Cheese!: Operation Iraqi Freedom on Film," 33. 
"Dreamland," the squad's base (Figure 3.19). Shot with night vision, a soldier attempts to communicate with the man with his limited Arabic. Intercut within this conversation are shots of an American soldier presented in silhouette, looking out onto a barren field where a pack of wild dogs roam about Fallujah's outer perimeter (Figure 3.20). The stylistic choice of night vision in this scene helps convey the sense of estrangement felt by the soldiers. Their anxieties are twinned by the scene's aesthetic techniques, closely linked to the kind of spectatorship involved in science fiction cinema. Darko Suvin argues that the spaces of science fiction convey a high sense of detachment through what he identifies as a combination of "cognition and estrangement," the familiar and the unfamiliar. This is equally applicable to Occupation: Dreamland ${ }^{87}$ These ghostly-green spaces connote a high degree of detachment felt from the environment amongst the soldiers. One soldier explains: "this place used to be you know, a mecca. They had... working water fountains, ...hydraulic systems, ... and now this place is just a shit hole." Devoid of any signs of modern civilization technology, as described by the soldier, Fallujah is depicted as an inhospitable, uncivil, foreign environment, lacking the familiar markers of Western civilization.

Distaste for the urban battleground is matched by various criticisms of the objectives behind the war explained by many of the squad's members. The clash between

\footnotetext{
${ }^{87}$ Suvin proposes that "[science fiction] is... a literary genre whose necessary and sufficient conditions are the presence and interaction of estrangement and cognition, and whose main formal device is an imaginative framework alternative to the author's empirical environment." (27) My adoption of this description of the genre's main formal device for Occupation: Dreamland is used to convey that the subjects of the film often confess to the alienation they experience within Fallujah's borders, reflecting the gap between their native socio-geographic reality and that of the foreign in the Middle East. This mirrors the void between the science fiction writer's actual reality and those imagined. See Darko Suvin, "Estrangement and Cognition," in Speculations on Speculation: Theories of Science Fiction, eds. James E. Gunn and Matthew Canderlaria, (Lanham, MD: Scarecrow Press, 2004).
} 
official military objectives and the views expressed by those carrying them out is frequent. Private First Class Thomas Turner voices his frustrations with the purpose of the whole mission: "I want some answers. I want some clarification of what we're doing. I feel that everyday, everyday. ...I guess someone smarter than me knows what's going on." Tony Grajeda states that Occupation: Dreamland "[decontextualizes] the very reality it aims to convey." behind their mission. One soldier reads a letter he has received from a 14 year-old American elementary school student: "I like to watch Fox News. And my teacher, Tim, does not because he is a loser. I especially like to watch Bill O' Reilly. Again, my teacher does not." This letter provokes the different opinions that the squad members have in terms of how their mission is being achieved. Grajeda contends that " $[a]$ continuum from belief to doubt is in evidence within the single squad." ${ }^{89}$ This continuum is manifested cinematically through the camera's constantly shifting left and right panning movements. As the camera shifts left and right, one soldier complains about the abundance of right-winged media coverage of programs like The O'Reilly Factor. This is interrupted by another soldier claiming that, "at least Bush got off his ass and fucking did something." Before the two can get too far into their debate, Staff Sergeant Chris Corcione intervenes and orders his comrades: "[e]verybody look, we aren't going to talk about fucking politics," explicitly censoring the soldiers: "[b]ashing the administration on camera, that is something that's not done on camera."

\footnotetext{
${ }^{88}$ Tony Grajeda, "The Winning and Losing of Hearts and Minds: Vietnam, Iraq, and the Claims of the War Documentary," Jump Cut, (Spring 2007) http://www.ejumpcut.org/currentissue/Grajeda/text.html (accessed March 8, 2008).

${ }^{89}$ Ibid.
} 


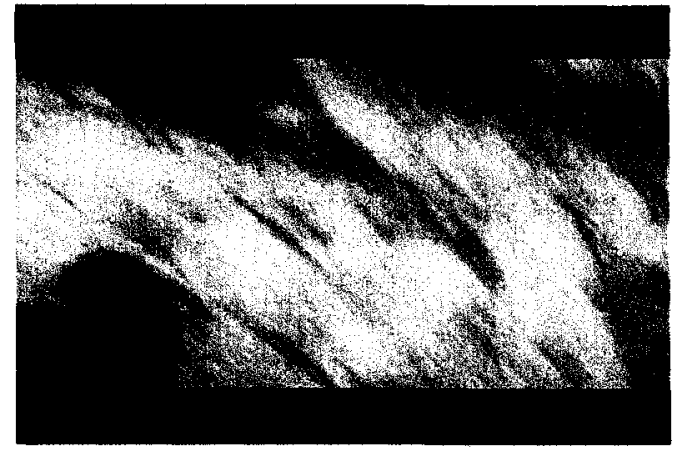

Figure 3.21 Occupation: Dreamland

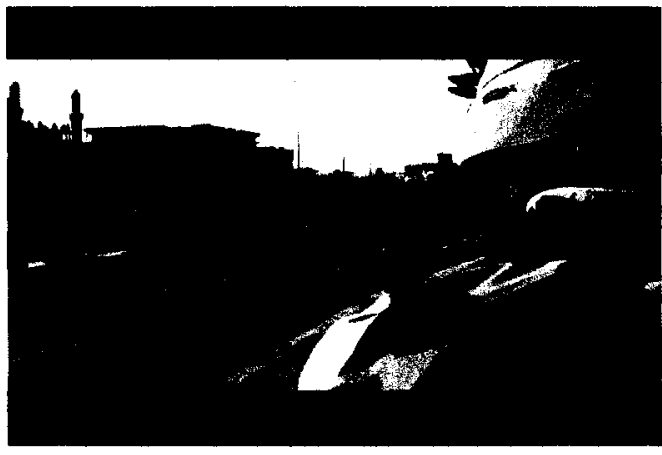

Figure 3.22 Occupation: Dreamland

Many of Occupation: Dreamland's images tend to speak louder than the words spoken by men like Corcione, who suggest that the camera is never critical of what it sees. The squad searches another house for evidence of firearms and leaves empty-handed. It appears that nothing concrete is ever found to prove the guilt of the men the squad incarcerates. Soldiers are often left wondering who it is exactly that they should fear. During one foot patrol, a soldier walks by a small group of civilians and greets them with, "how you doing?" As the group remains speechless, the soldier remarks: "Don't fucking stare at me like that, fucking asshole." The camera lingers on the Iraqi civilians momentarily as they stare blankly into its lens. Uncertain as to whether the civilians had intentionally ignored the soldier's friendly gesture or not signifies the friction and tension that exists between the occupiers and the occupied. Paranoia is constantly felt by the men on their patrols since anyone, they are told, can pose a deadly threat. In an interview, Scott explains that "the way we experienced Fallujah was a growing sense of anxiety." $"$ Near a busy highway, one squad member turns to the camera to initiate a conversation with the

\footnotetext{
90 "Garrett Scott and 'Occupation Dreamland' Take Us All To Fallujah," Buzzflash.com (January 25, 2006) http://www.buzzflash.com/interviews/06/01/int06003.html (accessed March 8, 2008).
} 
operator when a loud crash is heard nearby, followed by sounds of rapid gunfire. The camera drops down, capturing a moment of unintended reflexiveness as the camera operator's feet are caught on video as he falls beside a crouching Marine on high alert, continuing to record the action over the shoulder of the trooper (Figure 3.21 and Figure 3.22). This instance negates the filmmaker's role as a simple observer and witness to profilmic events, becoming as much a part of the film's action as its subjects.

This chapter has demonstrated the complexities of representing the war in Iraq through modern digital video technology through analyses of In the Valley of Elah, The War Tapes, and Occupation: Dreamland. These films represent war through the use of digital media with filmmakers preferring "amateur" aesthetics over more professional and conventional techniques commonly found in narrative fiction cinematography. In the Valley of Elah thematises the kind of "amateur" aesthetics that the other documentaries in this chapter utilize. However, these "amateur" aesthetics are, in fact, not really "amateur" at all, as suggested before. But, they are conscious technical decisions that these filmmakers use to appeal to various principles of realism that are tied to re-imagining the subjectivity of the person holding the camera onto the image. This results in an anthropomorphization of the cinematic apparatus, postulating that the look of the camera is that of the operator. These films offer ambivalent and complex accounts of what war means in today's society, mirroring the on-going struggle for an adequate definition and explanation of the war in Iraq and the larger "War on Terror." However, these films and these stories are, by and large, told from the perspective of the occupying forces, lacking any real agency on the part of the people who inhabit the civilian spaces of this war. The next chapter will discuss other war films that include testimonials from the Iraqi people 
themselves. These films represent a smaller group of American- and/or British-produced Iraq war films that offer a candid account from a civilian perspective of what it means to live in a war zone. 


\title{
CHAPTER THREE
}

\section{Advocating the Localized Perspective in War Images}

\begin{abstract}
America's new world hegemony has mainly made itself felt by an arrogance based on its crushing technical superiority rather than on its elevated morality.
\end{abstract}

Paul Virilio, Ground Zero

When [Virginia] Woolf notes that one of the photographs she has been sent shows a corpse of a man or woman so mangled that it could as well be that of a dead pig, her point is that the scale of war's murderousness destroys what identifies people as individuals, even as human beings. This, of course, is how war looks when it is seen from afar, as an image.

Susan Sontag, Regarding the Pain of Others

The films that have been discussed in this thesis thus far have focused primarily on the American military experience of war. The local, civilian perspective of the war is largely ignored in western media and is specifically what the films in this chapter seek to rehabilitate. These films demonstrate that war inevitably intrudes on the lives of the innocent, despite America's host of 'intelligent' weaponry. Slocum notes film scholar Bruce Franklin's observation that both Hollywood war films and American war coverage tend to celebrate American military good,

writing after the first Gulf War, [Franklin] observed that the conflict had been projected 'from the point of view of the weapons,' building on Hollywood's tradition of "warplane romances," like Strategic Air Command (1955), starring Jimmy Stewart, and creating "the impression of a 'clean' techno-war, almost devoid of human suffering and death, conducted with surgical precision by wonderous mechanisms. ${ }^{91}$

Despite such dreams of a "clean techno-war," according to a March 23, 2008 news report on ABC News, US military casualties were estimated at around $4,000 .{ }^{92}$ And on the

\footnotetext{
${ }^{91}$ J. David Slocum, "General Introduction: Seeing Through the American War Cinema," in Hollywood and War: The Film Reader, ed. J. David Slocum 18, (New York: Routledge, 2006).

${ }^{92}$ Robert H. Reid, "US Death Toll in Iraq hits 4000," $A B C$ News http://abcnews.go.com/International/WireStory?id=4503587\&page=1 (accessed April 21, 2008).
} 
infamous "Iraq Body Count" website, as of April 21, 2008, non-combatant deaths from war-related violence since the 2003 "Shock and Awe" US-led bombing campaign were estimated between 82,987 to $90,521 .^{93}$

In some of the films discussed in previous chapters, the war in Iraq appears to be fought with the use of advanced military technology such as high-speed communication networks, night vision, thermal imaging, and precision guided weaponry (like 'smart' bombs) - all utilized to minimize the number of civilian casualties by targeting enemies more effectively. However, many scholars have argued that with the introduction of visual technology came a whole host of serious psychological issues for "men at war." Huppauf argues that since the adoption of aerial photography for reconnaissance in WWI, the battlefield has been reconfigured and abstracted from its real geographic existence:

Aerial photography then, creating a metalevel of artificiality, further abstracted from the "reality" of this artificial landscape. It not only eliminated smells, noises, and all other stimuli directed at the senses, but also projected an order onto an amorphous space by reducing the abundance of detail to restricted patterns of a surface texture. ${ }^{94}$

Devices of abstraction, like aerial photography, eliminate the immediate sensory experience of combat - targeting your "enemy" can now be done through video screens at the push of a button, having never to physically confront your foe. Jean Baudrillard states in his provocatively titled book, The Gulf War Did Not Take Place: "[N]o one wants to hear talk of the other. Ultimately, the undecidability of the [Gulf War] is grounded in the

\footnotetext{
${ }^{93}$ The Iraq Body Count (IBC) project involves US and UK individuals who have compiled a website that displays an ever-changing tally of war related civilian deaths since operations began in Iraq in 2003. The site claims that all figures are derived from western and non-western media sources and states that figures are likely underestimating the real number of deaths since it gathers all of its information from various media reports that may have various ideological slants towards the war or that all civilian deaths are not necessarily reported to the news media. See http://www.iraqbodycount.org/ .

${ }^{94}$ Bernd Huppauf, "Experiences of Modern Warfare and the Crisis of Representation," 60.
} 
disappearance of alterity, of primitive hostility, and of the enemy. War has become a celibate machine."95 And especially since the First Gulf War, theorists like Baudrillard believe that war has become a total technological and televisual simulation, combining the use of advanced visual weaponry and speculative media coverage to abstract the real destruction and devastation that an advanced mode and promotion of combat actually inflicts on people. The films in this chapter, however, remind viewers that despite the technological precision of military weaponry, the death and suffering of innocent people cannot be eliminated. These films are critical of the proliferation of modern representations of war, on both a formal and narrative level, focusing primarily on the emotional, psychological, and physical toll of America's image-based war machine on civilians.

The Road to Guantánamo, Iraq in Fragments, and The Blood of My Brother are the central texts that will be analyzed in this chapter. I will argue that these films formally challenge the narrative of the war in the Middle East by avoiding the sort of testimony from military personnel that accompany other contemporary war films like those discussed in Chapter Two. It should be noted that the filmmakers of these films are either American or British and are not citizens of any of the Middle Eastern nations depicted in their films. These directors are rather, advocates for the people, facilitating their stories and testimonies through cinema for international audiences to observe. ${ }^{96}$ The Road to

\footnotetext{
${ }^{95}$ Jean Baudrillard, "The Gulf War Did Not Take Place," in Jean Baudrillard: Selected Writings, Trans. Mark Poster (Stanford, CA: Stanford University Press, 2001), 239.

${ }^{96}$ The main films in this chapter have either picked up numerous prestigious awards or were selected to be screened at several international festivals. The Road to Guantánamo won the Silver Bear award at the 2006 Berlin International Film Festival. Likely the most critically acclaimed film of the trio, Iraq in Fragments was screened at the 2006 Sundance Film Festival and was nominated in the best documentary category for the Academy Awards of the same year. And The Blood of My Brother had a world premiere at the 2005
} 
Guantánamo will be analyzed as a text that addresses the arbitrariness of fact and fiction by utilizing a docu-drama mode of address (including re-enactments, interviews, and archival news footage), but that suggests, nevertheless, that images can tell $a$ truth, even if it this is only partial - a strategy that Winterbottom has deployed before in 24 Hour Party People (2002) and In This World (2002). ${ }^{97}$ Iraq in Fragments will be discussed in terms of its structural complexity and high level of access Longley had to the film's subjects. As a story literally told in narrative fragments, Iraq in Fragments exhibits a "tripartite structure focusing on Sunni, Shiite, and Kurdish Iraq."98 By relying on testimonies of people from various cultures, religions and regional identities in Iraq, Longley creates a cinematic mosaic, resisting the hegemony of narrative singularity. The portrait of insurgent and civilian alienation in The Blood of My Brother will be discussed in the last section of this chapter. Andrew Berends, the film's director, goes behind enemy lines to document insurgent activity and the explosion of anti-American protests and attacks in Iraq. Berends embeds himself with anti-American rallies, insurgent activity, and unexpected urban cross-fires. The films in this chapter represent the real horrors and terror of the war from a non-American perspective.

Amsterdam International Documentary Film Festival and premiered in the US at the 2006 Tribeca International Film Festival Documentary Competition.

${ }^{97}$ From hereon in, I will refer to Winterbottom as the film's director since he had demonstrated greater authorial control over the production of the film than his co-director, Matt Whitecross, who was mainly in charge of preliminary research and interviews. In an interview for Film 4, Michael Winterbottom discusses how his co-director, Mat Whitecross, had conducted interviews with the Tipton Three for about a month and came up with a 650 page transcript for Winterbottom to use during the production of The Road to Guantánamo. His role in the production of the film is never mentioned explicitly again, although, it should be duly noted that Winterbottom uses the personal pronoun "we" quite often when discussing how and why things were done for the film. But, I refer only to Winterbottom when referring to the director of the film because Whitecross's directorial duties, besides the preliminary interviews, are never clearly established. For this interview, see http://www.channel4.com/film/reviews/feature.jsp?id=154599\&page=3.

${ }^{98}$ Bilge Ebiri, "The Ravages of War and Occupation: An Interview with James Longley," Cineaste 32:1 (2006), 38. 


\section{I: Of Docu-Drama and Dialectics - The Road to Guantánamo}

The Road to Guantánamo is not about the war in Iraq per se, but is more concerned with the implications of the larger "War on Terror." The film is set in the days after the 9/11 attacks, before operations had commenced in Iraq. Based on a true story, Winterbottom intercuts the testimony of three British Muslims known as "The Tipton Three" (Ruhal Ahmed, Asif Iqbal and Shafiq Rasul) with dramatic re-enactments of their journey through Afghanistan and eventual imprisonment at the Guantánamo Bay detention centre, otherwise known as "Camp X-Ray." Winterbottom's narrative alternates between interviews with real the Tipton Three, television news footage, and dramatizations of events covering their two years of torture and psychological abuse in Guantánamo.

Mirroring the cinematic approach of the juxtaposition of interviews and highlystylized re-enactments in Errol Morris's The Thin Blue Line (1988), Winterbottom attempts to reconstruct events and investigate how these three men came to be accused of terrorist activities through a narrative that shifts between multiple modes of address. In an on-line interview with Film 4 correspondent Benjie Goodhart, Winterbottom explains why he chose to structure the film this way:

The main way in which we learned what happened to them was by them telling us in direct interview. [W] wanted to show the gap between what you thought people would be like in Guantánamo and the reality of meeting them. The simplest and most effective way to tell their story was to have them tell it within the film. ${ }^{99}$

Winterbottom learned about the incident through newspapers and television coverage, and wanted to probe deeper. Juxtaposing interviews with archival footage and re-enactment

\footnotetext{
${ }^{99}$ Benjie Goodhart, "Michael Winterbottom on The Road to Guantanamo," Film 4 http://www.channel4.com/film/reviews/feature.jsp?V=3\&SV=5\&id=154599 (accessed March 29, 2008).
} 
sequences, Winterbottom explains that, "because all of us saw what was happening in Afghanistan through the news, [we wanted] to remind people what was going on," and that this narrative strategy was utilized "[p]artly to contrast between the men's experiences on the ground as three individuals caught up in it compared to us watching it from the outside. ${ }^{100}$ Winterbottom's balancing act of intercutting interviews and news media footage within the film highlights the televisual mediation of the current war and how news media shape how an event is consumed by a geographically distant audience, contrasting with how the same event is experienced by individuals on the ground. Winterbottom insists that we need to pay special attention to the function of these images in our surrounding visual culture, or, as Marc Furstenau puts it, given the extent of networks of image distribution, "[i]t must be acknowledged that, far from being diminished, images matter more now, perhaps, than ever." 101

The Road to Guantánamo tells a story that Winterbottom felt was neglected by western news media: a story about the "War on Terror" told from a dual perspective. He insists that during initial operations in Afghanistan,

on a slightly more specific basis, virtually all the news that we were seeing was from the point of view of the cameras and news crews who were with the Americans or the Northern Alliance, they weren't in the places where [the Tipton Three] were. So you get a double perspective - them on the ground being bombed as opposed to reporters with the guys doing the bombing. ${ }^{102}$

\footnotetext{
${ }^{100}$ Goodhart, "Michael Winterbottom on The Road to Guantanamo".

${ }^{101}$ Marc Furstenau, "The Ethics of Seeing: Susan Sontag and Visual Culture Studies," Post Script 26:2 (Winter/Spring 2007); 104.

${ }^{102}$ Goodhart, "Michael Winterbottom on The Road to Guantanamo".
} 


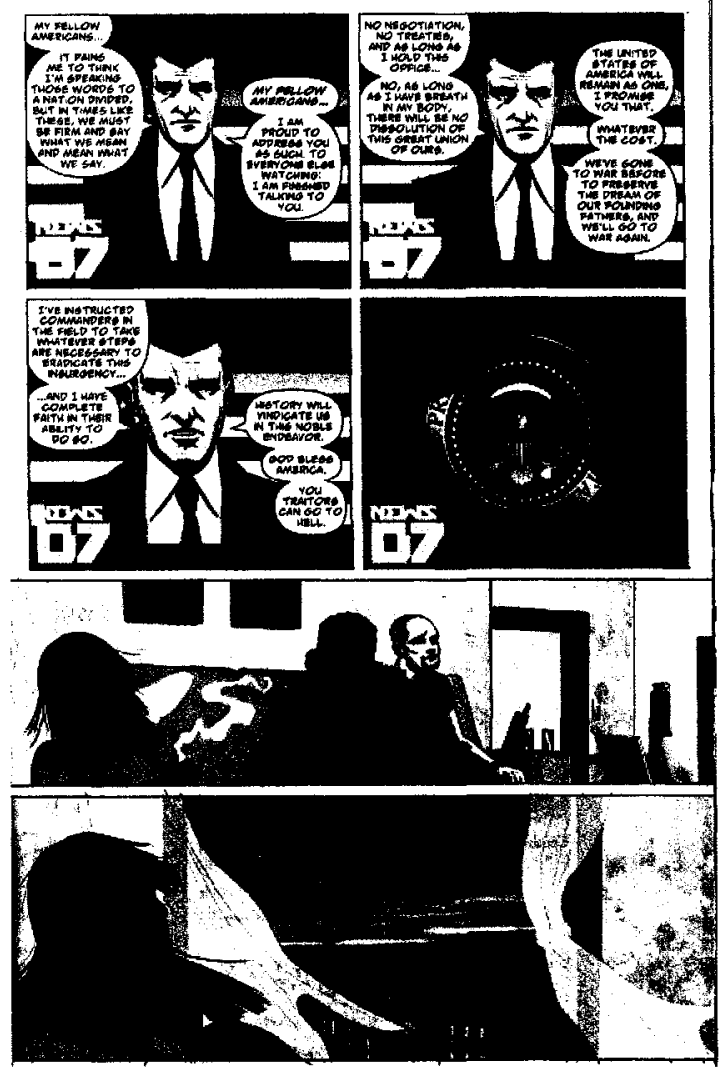

Figure 4.1 DMZ (Brian Wood and Riccardo Burchielli, 2006-present)

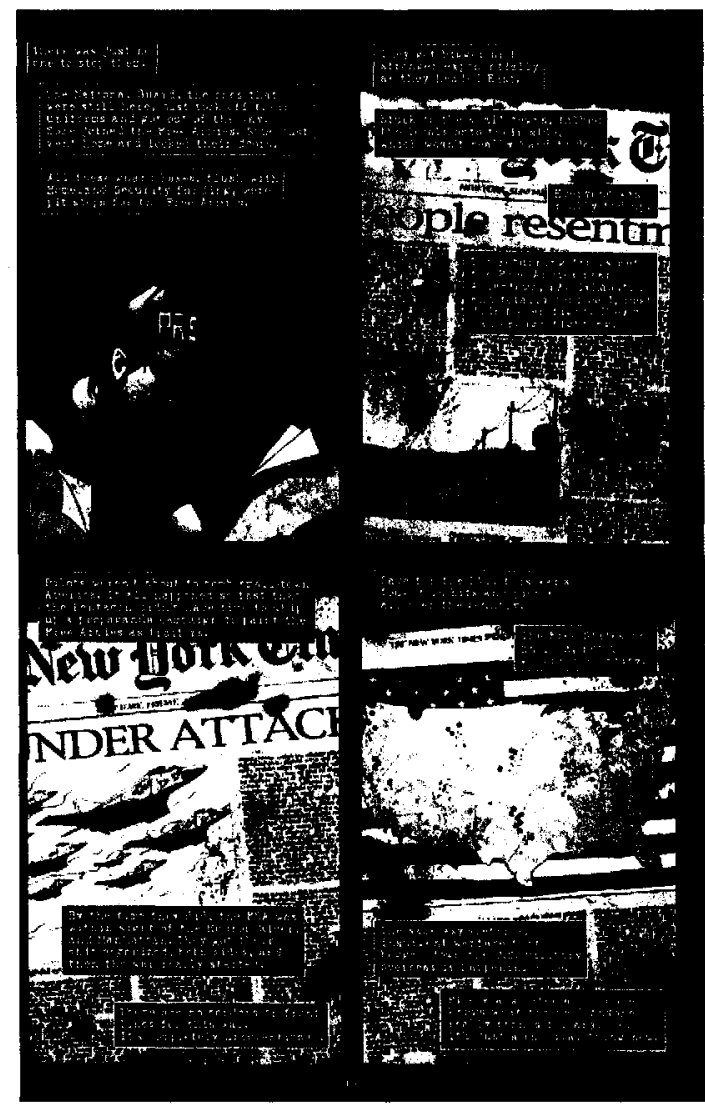

Figure 4.2 $D M Z$

This fracturing of perspective, contrasting a mediated gaze with one on the ground, is a narrative device employed regularly throughout the comic book series, DMZ (Brian Wood and Riccardo Burchielli, 2006-present). Television broadcasts, newspaper headlines, and photo montages often come to surface throughout the comic to contrast how bureaucrats and the news media rationalize the civil war being fought between the US government and an anti-government organization known as the "Free States" on Manhattan Island (known in the comic as "no-man's land" or the "DMZ") versus the chaos of the civilian characters caught in the middle of both warring sides (Figure 4.1 and Figure 4.2). Winterbottom 


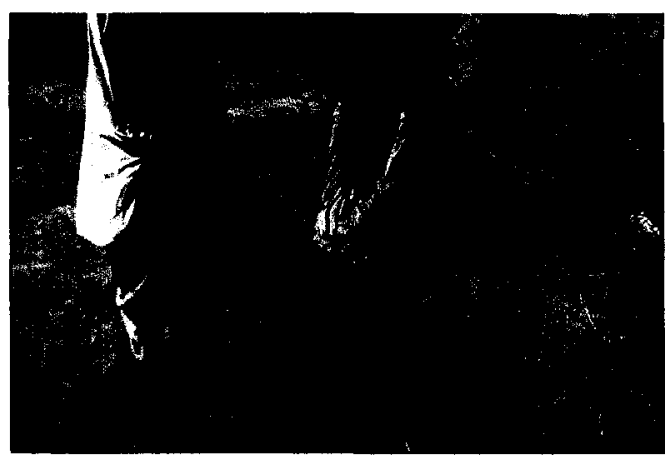

Figure 4.3 The Road to

Guantanamo (Michael

Winterbottom and Mat

Whitecross, 2006)

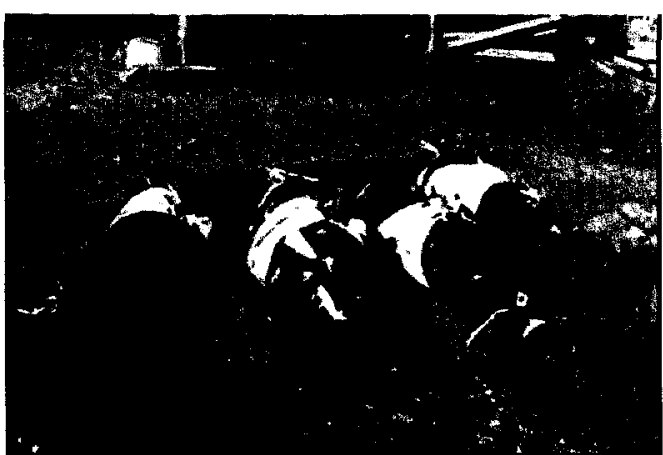

Figure 4.4 The Road to Guantanamo

alternates between mediated and unmediated perspectives. In one scene, the trio seeks refuge outside of the city of Kunduz shortly after the city had become the target of an Allied forces bombing campaign. The men come across a small village that had been devastated by the attack, with bodies scattered on the surrounding landscape. The film's fractured perspective is conveyed in the re-enacted digital video images that depict the burying of bodies from the previous night's violence intercut with broadcast-quality footage of bodies wrapped in cloth (Figure 4.3 and Figure 4.4). Contrasted by varying picture qualities, these shots are intercut together in a less seamless and more visible fashion, revealing the competing perspectives. Winterbottom never produces a narrative that hides or conceals its various media imagery. Its multimedia appearance is used to expose the different representations of events that are experienced by those that live them first-hand, but which are watched by others.

The Road to Guantánamo is a film that is about the hyperreality of war and modern communication through its multimedia guise; however, I do not want to suggest that this would also make it a hyperreal film. "Today abstraction is no longer that of the map, the double, the mirror, or the concept," Baudrillard suggests in his 1994 book, Simulacra and 
Simulation, "[s]imulation is no longer that of a territory, a referential being, or a substance. It is the generation by models of a real without origin or reality: a hyperreal."103 Baudrillard's notion of hyperrealism is that the boundaries of reality and virtuality (or simulations of reality found in such image-based media like television, advertising, and the cinema) have collapsed. However, the boundaries between reality and virtuality in The Road to Guantánamo never implode on each other. Baudrillard's notion of hyperrealism does not apply to Winterbottom's mode of filmmaking since the multimedia images in the film never simply blend together to construct a seamless narrative. Instead, Winterbottom draws attention to our mediated viewing experience of the story of the Tipton Three.

The Road to Guantánamo presents viewers with a strategy for actively comparing the stories created by the media with the men's personal accounts. Winterbottom's organization of multimedia imagery supplements and helps illustrate the testimonies of the real Tipton Three depicted in the interviews. He does not utilize these images to challenge the trio's story. Winterbottom has said that the film was never meant to be critical of their story: "The events ...regarding what happened to them in Afghanistan onwards, all seem to be fairly indisputable. ...I wouldn't remotely want to suggest that I think what they're saying is not true."104 The film's re-enactments or archival footage are used primarily for illustrative purposes and never seem to detract from what is said in the interviews similar to the use of B-roll footage in electronic news gathering.

\footnotetext{
103 Jean Baudrillard, Simulacra and Simulation, (Ann Arbour: University of Michigan Press, 1994); 1.

${ }^{104}$ Goodhart, "Michael Winterbottom on The Road to Guantanamo".
} 
Winterbottom's narrative web is not spun to be critical of their story, but used to supplement it. The film's multimedia narrative appearance invites viewers to be active in their spectatorship. Winterbottom is reproducing the complex visual and evidential context within which viewers must make judgements about events, which primarily take the form of photographs and other visual representations. As Furstenau claims in "The Ethics of Seeing: Susan Sontag and Visual Culture Studies," adopting a similar position as Sontag regarding our contemporary image culture:

Photographs have not distanced us from reality. They have, quite to the contrary, enlarged and expanded our sense of reality, and, at the same time, they have contributed to the production of a complex and subtle context within which we have to make judgements and determinations about that reality. ${ }^{105}$

Winterbottom's utilization of multiple media images is never invisible, allowing for a more contemplative and engaged viewing experience, allowing spectators to form their own opinions and judgments about the information conveyed in the media images, and to contrast this with what the three men say in their interviews.

The overall structural logic of The Road to Guantánamo is what Bill Nichols describes as collage film, the challenge of which, he argues, "is to untrack narrative without destroying it, ...[r]etardations, delays, slippages, ... fissures, gaps or other peripeteias mark this strategy." 106 The Road to Guantánamo does not deconstruct the centrality of narrative and history in the Derridean sense. ${ }^{107}$ The film "untracks narrative"

\footnotetext{
${ }^{105}$ Furstenau, "The Ethics of Seeing: Susan Sontag and Visual Culture Studies," 100.

${ }^{106}$ Bill Nichols, Blurred Boundaries: Questions of Meaning in Contemporary Culture, (Indianapolis: Indiana University Press, 1994); 120.

${ }^{107}$ See Daniel Punday, Narrative After Deconstruction, (New York: SUNY Press, 2003); 43. Punday investigates the narrative implications of Derrida's book 1993, Spectres de Marx: l'état de la dette, le travail du deuil et la nouvelle Internationale (Specters of Marx: The State of the Debt, the Work of Mourning, and the New International). Punday explains Derrida's deconstruction of the discourse of Karl Marx and Marxism as such: "[Derrida] wants to treat Marx not as an historical person but as a figure that shuttles back
} 
by drawing our attention to the building blocks of narrative reconstruction through the collage of multimedia imagery.

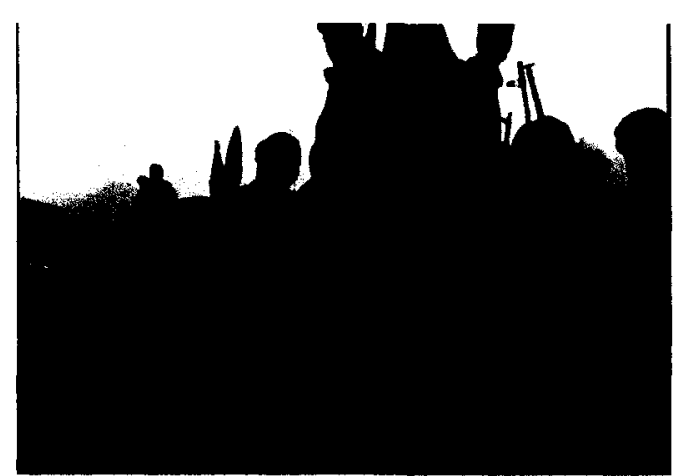

Figure 4.5 The Road to

Guantanamo

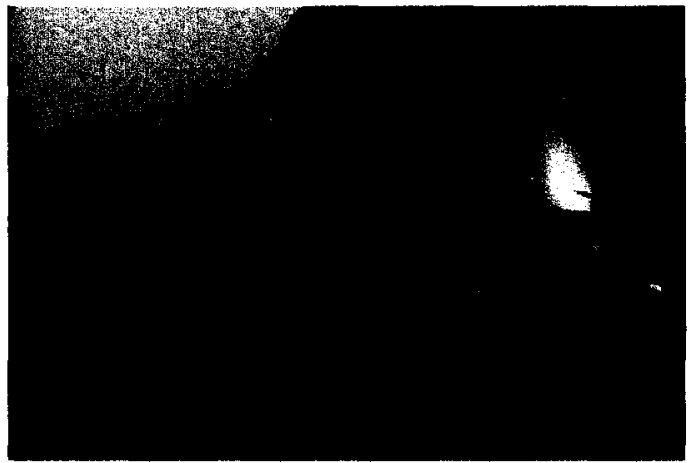

Figure 4.6 The Road to Guantanamo

An example of the film's collage of media materials is a scene that depicts news coverage featuring a British news reporter discussing the surrender of Taliban fighters to the Northern Alliance (Figure 4.5). An interviewee is heard in a voice-over, followed by images of the threesome riding along in the back of a truck, explaining the harsh and brutal treatment that the surrendering members of the Taliban and foreigners are receiving: "We came out with this hope that they are our brothers, that they would not abuse us or treat us badly." (Figure 4.6) The ill-treatment described in the man's statement is reinforced by dramatized footage of the fictional Tipton Three being taken off a truck to be interrogated by Northern Alliance soldiers. The men are shown being

and forth between real-world influence and textual construction," and later adds, "Derrida casts the 'specter' of Marx as an ontologically indeterminate, both concrete and conceptual, and actual and ideal." Derrida's notion of indeterminacy is not analogous to Winterbottom's story presented in The Road to Guantanamo. Winterbottom has said that he did not want to present the inadequacies of the Tipton Three's story thereby choosing to not deconstruct the film's narrative. It is ironic that Winterbottom would not take this route he has taken before with a film like Tristram Shandy: A Cock and Bull Story (2006) - a deconstruction of the British Heritage film with its frequent use of reflexive techniques such as direct-address and notable, present-tense context. 
shoved, herded and intimidated by the soldiers, with one Northern Alliance fighter sticking his rifle in the faces of the men. The real Shafiq, shown in interview, describes the brutality that he experienced in the altercation: "I thought the guy was going to kill me because he wouldn't stop pointing his gun at me." The re-enacted images operate as supplemental to the British news report and Shafiq's testimony, presenting visual evidence and a narrative context to the Taliban fighter's and Shafiq's description of the incident. On a strictly formal level, each type of image contrasts with the next to activate our engagement with the film's narrative reconstruction.

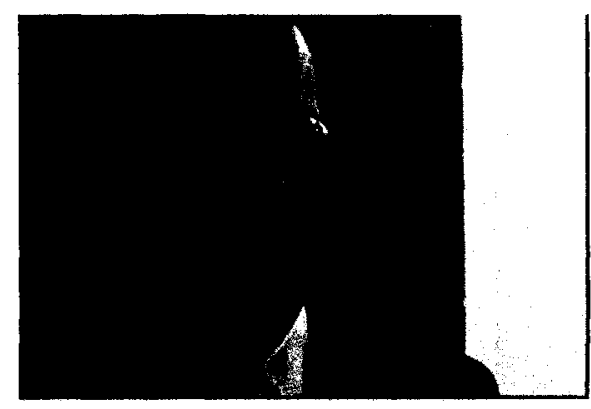

Figure 4.7 The Road to Guantanamo

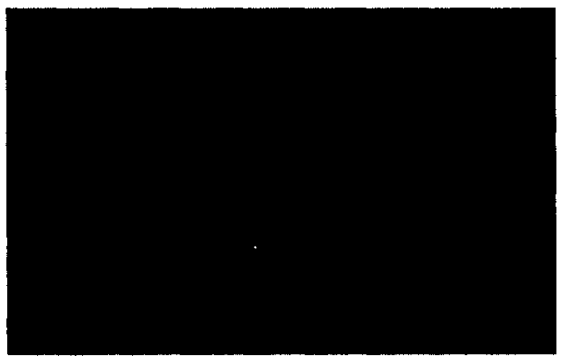

Figure 4.9 The Road to Guantanamo

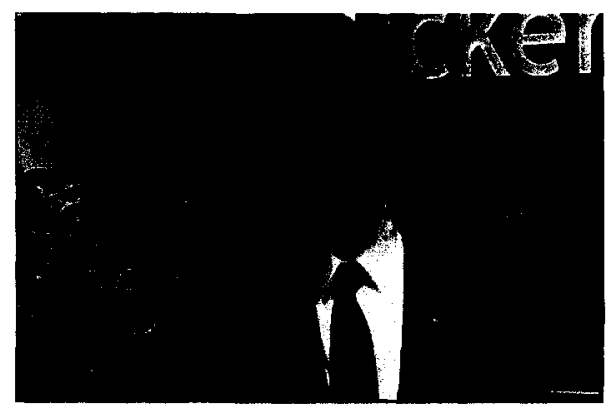

Figure 4.8 The Road to Guantanamo

The juxtapositions of various media are also present in Winterbottom's depiction of the trio's time in Guantánamo Bay. Upon arrival, news footage depicting distant shots of a plane landing and of a prisoner being

guided behind a chain link fence are followed by interview footage of then-Secretary of Defense, Donald Rumsfeld. Rumsfeld is depicted responding to international criticism concerning the treatment of detainees at Camp X-Ray: "The fact remains, the treatment is 
proper and that there is no doubt in my mind that it is humane and appropriate and consistent with the Geneva Convention for the most part." (Figure 4.7) Next, President Bush is presented beside a banner that reads, "Caring Children," with emphasis on the word, "Caring" which is in bold black letters. Speaking to the press about the types of people that are incarcerated at Guantánamo, he says: "Remember these are the ones who at Guantánamo Bay are killers. They don't share the same values we share." (Figure 4.8) These media sound-bytes are followed by shots of military police carrying a detainee wearing opaque goggles into a fenced-in area, taunted by the snarls of German Shepherds (Figure 4.9). Captives are forced to bow their heads down and kneel in regimented rows under the sweltering sun, as one officer tells them: "You are now the property of the US Marine Corps. This is your final destination." The juxtaposition of the confident words of American politicians with the grim realities of captivity at Guantánamo is a classic instance of what Sergei Eisenstein described as montage through "collision." By juxtaposing images of Rumsfeld and Bush's claims with images of the inhumane actions of US Marines, Winterbottom reveals the contradiction between the official account and the realities on the ground.

In contrast to the film's highly subjective engagement with its characters' story, the narrative of the film is organized in a fairly conventional, 'cause-effect' manner, but this structure is always made visible to the viewer. Winterbottom takes his viewers through a 'step by step' chain of events depicting how the men ended up on their trip from hell. The syntactic elements of The Road to Guantánamo (re-enactments, interviews, media footage) are not invisible nor is their narrative arrangement ever rendered seamless. Nichols suggests that films inspired by real events that highlight narrative construction 
enable viewers to adopt a heightened sense of historical consciousness. He defines

historical consciousness as

something akin to consciousness raising: an awareness of the present in relation to a past active within it and a future constantly being made in the thick of the present, together with a heightened consciousness of one's relation to others in the common project of the social construction of reality. ${ }^{108}$

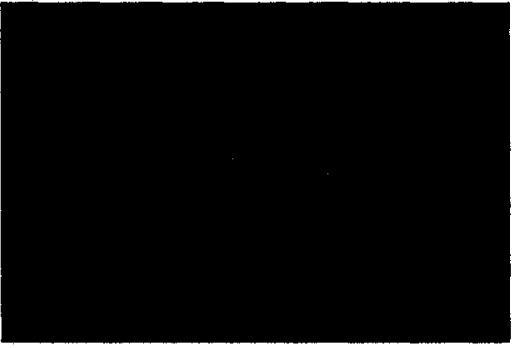

Figure 4.10 The Road to Guantanamo

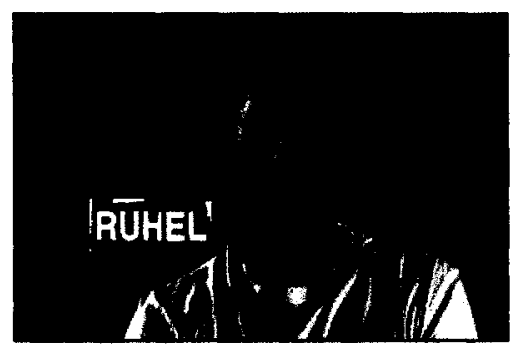

Figure 4.12 The Road to Guantanamo

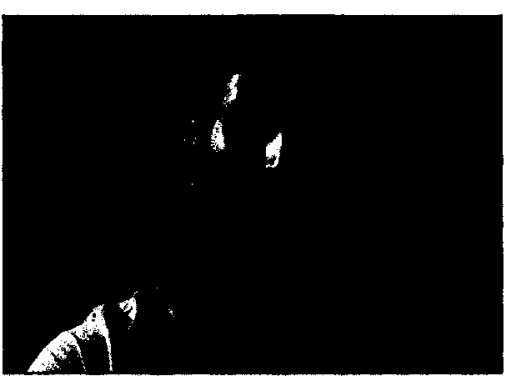

Figure 4.14 The Road to Guantanamo

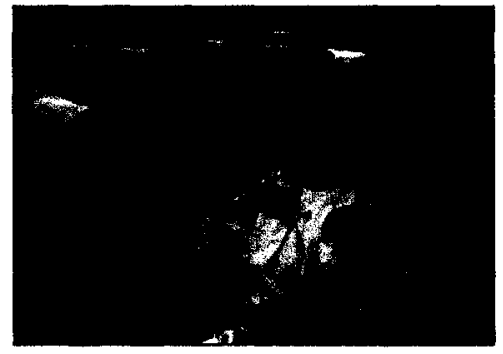

Figure 4.11 The Road to Guantanamo

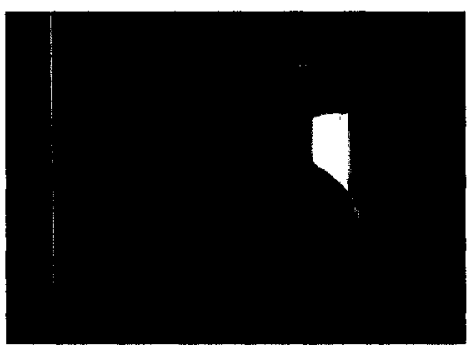

Figure 4.13 The Road to Guantanamo

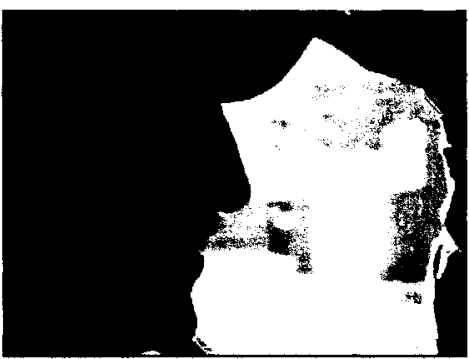

Figure 4.15 The Road to Guantanamo

\footnotetext{
${ }^{108}$ Nichols, Blurred Boundaries: Questions of Meaning in Contemporary Culture, 60.
} 
The Road to Guantánamo is not presented as a transparent historical document, but rather reveals the processes and tools of historical narrative reconstruction.

The present-tense nature of the film's re-presentation of past events is constantly called attention to, notably in the visible physical differences between the real-life Tipton Three, represented in the present, and their fictional counterparts representing their past (Figure 4.10 - Figure 4.15). The actors and the interviewees are obviously two different sets of people. Hairstyles and body types represent an important point of contradiction between social and fictional actors. For instance, Ruhel is medium-build and has a closely shaven head, whereas his fictional counterpart thinner and has short black hair. The obvious distinctions that separate the real men from their fictional equivalents establish the narrative juxtaposition of the men's present versus Winterbottom's reconstruction of their past.

Four to five years passed between the time that the events in the film occurred and when they were depicted on-screen, presenting a retrospective story. Nichols states: "As we retrospect, we construct a story (histoire) from our present perspective but mediated by what we now understand of past events in the plot to which we contribute, in 'the story so far.",109 The film's interviews are intercut intermittently with other narrative devices throughout the film, representing the present-tense and subjective nature of the film's story. Furthermore, in the re-enactments, the camera never strays far from the sides of the men from their departure from the Midlands to their eventual incarceration at Guantánamo. Winterbottom explains: "We're telling their story in their words, and trying to tell their version of what happened to them, just as a lawyer would tell their version of 
what happened to them."110 Winterbottom's lawyerly reference reinforces the notion that his role as a film director is to simply facilitate the means of telling their story on-screen, of acting on the trio's behalf as a cinematic advocate. In his statement, Winterbottom does not claim to represent the complete and whole truth of what had happened. He acknowledges the partiality of witness testimony and subjective interpretation when he claims that the film is "[the Tipton's Three] version of what happened," and not his.

\section{II: “Collaborative Histories" and A Nation Divided - Iraq in Fragments}

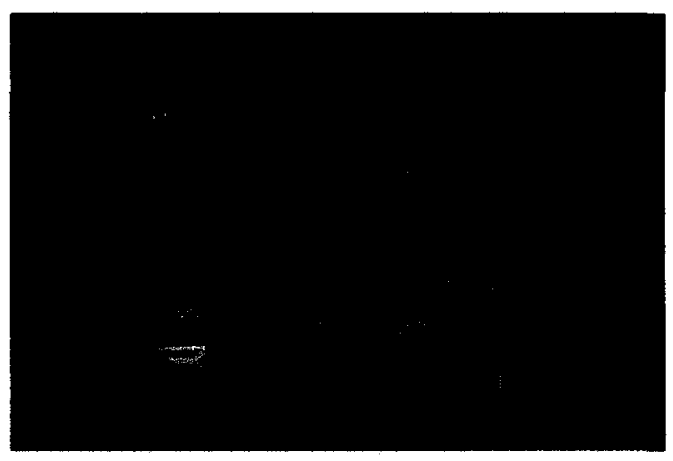

Figure 4.16 Jarhead (Sam Mendes, 2005)

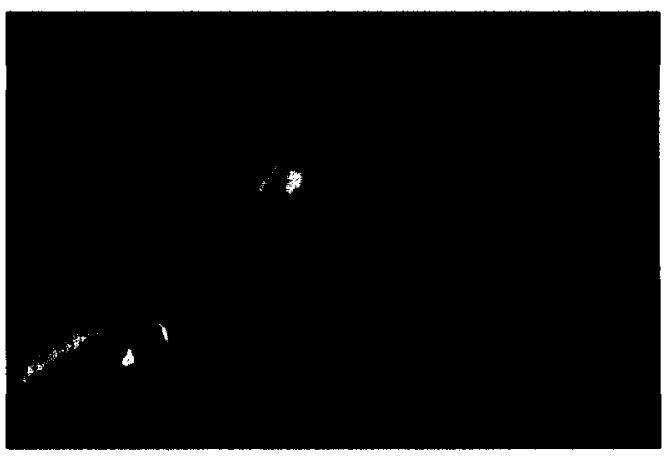

Figure 4.17 Jarhead

In his book, Welcome to the Desert of the Real!: Five Essays on September 11 and

Related Dates, Slavoj Zizek states: “On today's market, we find a whole series of products deprived of their malignant properties: coffee without caffeine, cream without fat, beer without alcohol, ...the Colin Powell doctrine of warfare with no casualties as warfare without warfare."111 This notion of a "clean war," devoid of the brutality associated with

\footnotetext{
${ }^{109}$ Ibid., 118-119. His emphasis.

${ }^{110}$ Goodhart "Michael Winterbottom on The Road to Guantanamo".

${ }^{111}$ Slavoj Zizek, Welcome to the Desert of the Real!: Five Essays on September 11 and Related Dates (New York: Verso, 2002), 10-11.
} 
past conflicts, appears in a scene from Jarhead, a film about the obscuring of the violent facts of war. Situated within the context of the First Gulf War, Sam Mendes' Jarhead largely omits scenes of combat with the Iraqi enemy with a few exceptions - one being Anthony Swofford's (Jake Gyllenhaal) task to murder two important Iraqi airbase officers. Given a rare opportunity to put his expert sniper skills to use, Swofford takes refuge in an abandoned look-out tower outside the airfield and aligns his human target in the middle of his scope's cross-hairs (Figure 4.16). Swofford remarks: "That's what they look like, huh?" The impression of the enemy's general absence from Swofford's war experience encapsulated in this suggestive remark coincides with the invisibility of enemy combatants in the film. The Iraqi enemy is largely unseen or underrepresented in Jarhead. Swofford is soon denied the opportunity to engage his target when a superior officer enters the tower and modifies the approach of the mission from sniper fire to air support. The disappointment of Swofford's missed opportunity to engage in his first kill is depicted by his blank stare on the obliterated airfield appearing in the window's reflection (Figure 4.17). Jarhead criticizes the preference of more 'effective' modes of killing like air assault that render human beings as 'easily disposable objects.'

Iraq in Fragments is equally critical of films like The War Tapes and Occupation: Dreamland, which fail to depict the experiences of the civilian population. As suggested before, Iraq in Fragments is presented in a tripartite structure with three basic plot lines, each representing different regional parts and religious factions of Iraq. The first plot line is the story of a young boy's balance between work and education titled "Mohammed of Baghdad," the second is about the followers of the anti-US political figure, Moqtada al 
Sadr in the regions of Nasiriyah and Najaf in "Sadr's South," and the third concerns a Kurdish farming community amidst a local election in the "Kurdish Spring." Cineaste writer Bilge Ebiri interviewed Longley and made the following observation: "One could say that Gaza Strip [another Longley documentary] wore its politics on its sleeve, whereas Iraq in Fragments seems more ambivalent about the U.S. occupation." ${ }^{112}$ Longley responded:

I do think [Iraq in Fragments] represents my experience. The subject is much more complex. It's a huge, complicated country, with different political groups and a very long history. There are a lot of different players and perspectives in the film. The people in Northern Iraq have a very different opinion than the people in Baghdad. So the film reflects that, I think if I made a film to just express my own opinions, what value would that have? Everybody has his opinion. It's not my job to just express my own personal opinion. ${ }^{113}$

Like Winterbottom, Longley views himself as a mediator, an advocate for the people in his film - facilitating their stories in order to engage the participation of his audience. The complexity of the situation in Iraq is reflected in the film's fragmented narrative structure that surveys the troubled political landscape of war-torn Iraq through contrasting and varied personal stories, recalling the polyvocality of The War Tapes. Longley's depiction of events shifts between modes of observational, participatory and poetic documentary cinema. ${ }^{114}$

Besides the film's overall structure, Longley's resistance to a basic, singular retelling of the situation in Iraq is evident in his eclectic shooting style. Ebiri argues that "Iraq in

\footnotetext{
${ }^{112}$ Ebiri, "The Ravages of War and Occupation: An Interview with James Longley," 41.

${ }^{113}$ Ibid.

${ }^{114}$ In Bill Nichols' Introduction to Documentary, Nichols identifies six distinct modes of documentary filmmaking. They include: poetic, expository, participatory, observational, reflexive, and performative. See Chapter 6 "What Types of Documentary Are There?," pages 99-138 in Bill Nichols, Introduction to Documentary, (Bloomington, Indiana University Press, 2001).
} 
Fragments displays dazzling cinematic technique, with Longley's furious cutting and hectic camera movements providing an esthetic corollary to the ever-shifting reality of war." ${ }^{115}$ Longley's ever-shifting camera style between three modes of documentary (observational, participatory, poetic) coincide with the instability of the meaning of the war in Iraq for the various peoples of the nation, and for Longley himself. By not sticking to any one mode of address, Longley resists a single-sided interpretation of what the war means to the Iraqi populace. The opening images of the "Mohammed of Baghdad" section depicts this blend of documentary styles. Shot in slow motion, we see a crowded street thick with traffic, various market vendors, and masses of people, accompanied by a voice-over of young Mohammed describing the busy city life of Baghdad before occupation. Longley's cinematic technique is observational in its un-imposing camera positioning, enabling not a "fly-on-the-wall" aesthetic, but rather, a "fly-on-the-go," constantly shifting his proximity to his subjects. Longley's cinematic style is also participatory by its inclusion of subject testimony - Mohammed speaks to Longley, describing the affluence of Baghdad before the US-led invasion. And it is poetic, with Longley's temporal manipulations of the film's images, blending the motions of subjects and objects found in the street to create an impressionistic visual aesthetic, emphasizing the frantic behaviour of an affluent urban locale. The combination of these documentary modes produces a destabilizing effect on the viewer, offering a fractured and varied vision of Mohammed's ever-changing environment. Our relationship to the changing social

\footnotetext{
${ }^{115}$ Ibid., 38.
} 
terrain of Baghdad is one marked by both detachment and curiosity through Longley's oscillating film styles.

Longley's shifting modes of shooting was encouraged by his close collaborations with the film's subjects. Longley shot Iraq in Fragments by himself, editing it on his Apple Powerbook G4 with "close to two terabytes (two thousand gigabytes) of storage space" on two LaCie external hard drives during his stay in Iraq. ${ }^{116}$ He believed that his "one-man crew" approach helped him get the kind of candid access he was afforded during the film's production. Longley explains how he was comfortable enough with his subjects that he would be able to go back and forth between stories throughout the production of Iraq in Fragments: "All of my shoots were going on simultaneously - I would shoot one story for several weeks, and then I would go away and shoot another story for a while, then come back."117 On the surface, Iraq in Fragments is an ethnographic film involving an outsider's cinematic meditation on the Iraqi experience, but critics like Patricia Zimmerman suggest otherwise. Films like Iraq in Fragments, according to Zimmerman, actually redefine or revise the ethnographic documentary tradition since it is a film made "with" rather than "about" its subjects. Zimmerman refers to contemporary anthropologist and filmmaker, David MacDougall, and his redefined approach to ethnography known as collaborative histories:

...David MacDougall has proposed to move ethnographic film away from making a film "about" towards making a film "with." Rather than a filmmaking strategy that is an omniscient monologue, he proposes the act of cinema as a contemplative and participatory act which is always a relation and

\footnotetext{
${ }^{116}$ Featured on the "Director's Interview" segment on the second disc of the two-disc DVD edition of the film.

${ }^{117}$ Ebiri, "The Ravages of War and Occupation: An Interview with James Longley," 40.
} 
an encounter, an act of collaboration and dialogue between the subject and the person filming. MacDougall argues for interconnection rather than separation to produce a compound work and an elaborative, embodied knowledge. In elaborating his ideas about a collaborative ethnography, he explains, "The goal is not simply to present 'the indigenous view' nor to invade voyeuristically the consciousness of other individuals, but to see social behavior, and indeed culture, as a continual process of interpretation and invention."

A recent example of this approach to documentary filmmaking is Born Into Brothels (Zana Briski and Ross Kaufman, 2004), a film featuring the film's directors creating a photography club for troubled youths in the Red Light District of Calcutta, India, to document their own personal histories through photography. The children speak to the filmmakers about their hardships as children of prostitutes and poverty, fortified by the bleak and often disturbing images taken by the children showcased throughout the film. Iraq in Fragments never features Longley himself on-screen or in voice-over engaging personally with his subjects, but his intimate camera gaze suggests a close relationship and dialogue between filmmaker and social actor that existed beyond the camera's frame.

Longley's interpretative and interventionist mode of address with his subjects is recreated in the film through his editing and camera choices.

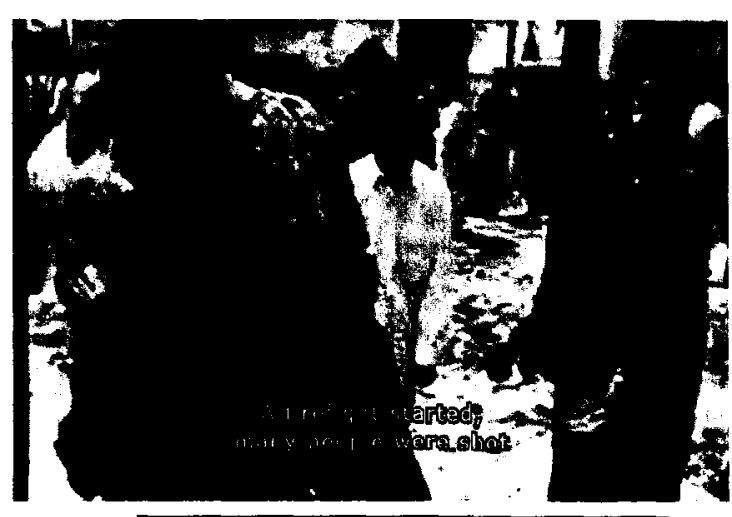

Figure 4.18 Iraq in Fragments (James Longley, 2006)

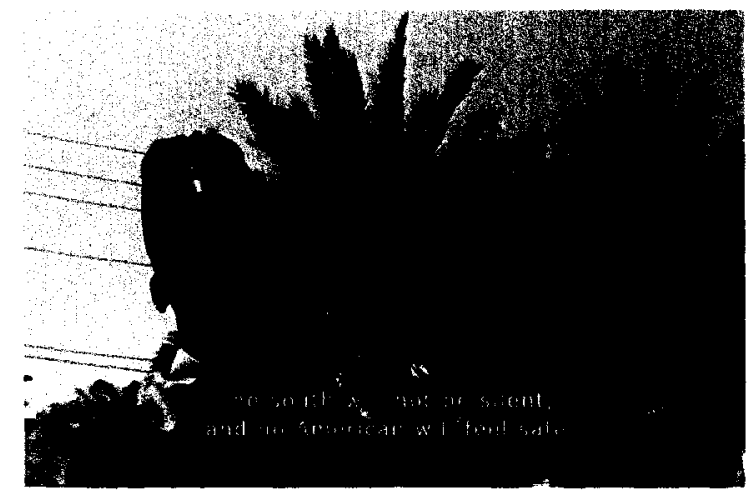

Figure 4.19 Iraq in Fragments

\footnotetext{
${ }^{118}$ Zimmerman, "Public Domains: Engaging Iraq Through Experimental Digitalities," 78-79.
} 
The close relationship that Longley developed with his subjects during the production of Iraq in Fragments appears in a scene from the "Sadr's South" section, where Longley depicts the Shiite uprising that took place in the spring and summer of 2004 , which was later followed by the eruption of violence in the city of Fallujah. These uprisings were anticipated from the growing influence that Moqtada al Sadr had gained among Iraqis, detracting civilian support from the US-installed Iraqi government. Intercut with amateur footage of a "peaceful demonstration" turned violent, one of Sadr's followers speaks to Longley about the volatile acts that had transpired during the events. In his review of the film, Geoffrey Macnab states that in Iraq in Fragments, "[t]here is no narration or editorialising. Longley uses voiceovers, but it is always the Iraqis themselves who are speaking."119 This is true of the testimony of Sadr's follower, which is contextualized with the amateur images that Longley intercuts in the scene. A montage sequence of amateur footage displays the chaotic fleeing of men, sounds of gun-fire, and the retrieval of bodies from the battlefield (Figure 4.18). The blurry images appear raw and amateur. ${ }^{120}$ The man then explains to Longley, translated into English in the subtitle, that, "[t]he south will not be silent, and no American will feel safe." (Figure 4.19)

\footnotetext{
${ }^{119}$ Geoffrey Mcnab, "Iraq in Fragments (Review)," Sight \& Sound 17:2 (2007); 62.

${ }^{120}$ In the "Director's Interview" DVD featurette, Longley explains that he used a Panasonic DVX100A MiniDV camcorder during the production of the documentary. Longley's footage and the amateur footage of the sequence described exhibit a notable difference in image quality. The amateur footage of the demonstration is highly-pixilated unlike the clearer and more pristine images of Longley's footage, suggesting that the demonstration footage was not shot by Longley and possibly by someone else who was present during the events since its images are of a visibly lower-resolution. It is never identified in the film who's footage this is or how Longley gained access to it, but considering the access that Longley was given to Sadr and his followers, it is most likely video shot by one of the demonstrators present.
} 
Paradoxically, this threat voiced to Longley's camera does not apply to him (despite the fact that he is American) - suggesting that Longley has an exclusive and unique relationship with the group. This scene encompasses Longley's exclusive access to the story. By juxtaposing amateur footage likely shot by another demonstrator with the testimony of the man, Longley is able to illustrate the growing anxieties and frustrations of the group and of the region with footage shot and explained by them.

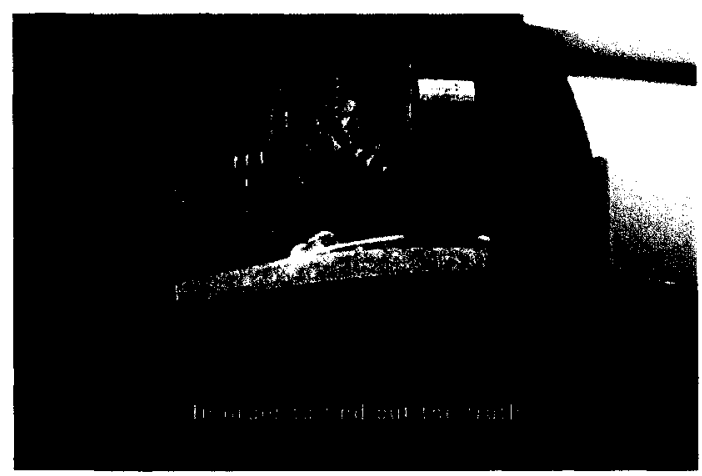

Figure 4.20 Iraq in Fragments

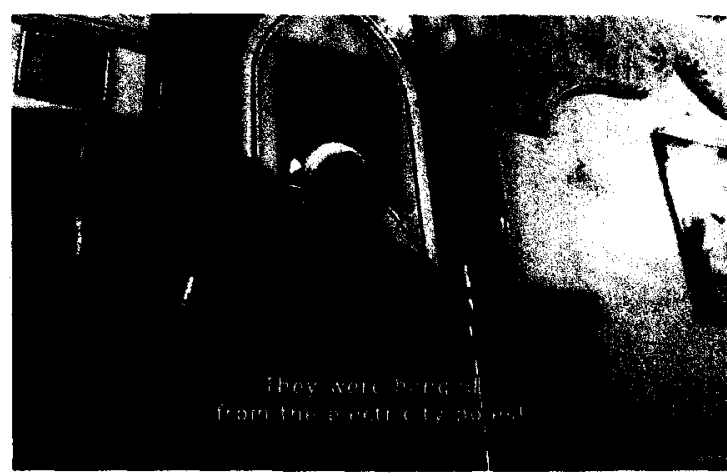

Figure 4.21 Iraq in Fragments

In the "Director's Interview" featurette on the two-disc special edition of Iraq in

Fragments, Longley explains how he was able to gain the trust of his subjects, notably the Sadr Organization: "They always knew when I was filming... I was nice to them. I had tea with them. I ate meals with them." In this sense, Longley established himself as a member of the group rather than as an outsider. However, Longley's camera never merely records or observes events. There is always a firm interpretative distance created in the film's editing and framing. Longley's interpretative handling of the film's events is confirmed in a scene that shows Sadr speaking in a mosque to followers on the gaps in America's foreign policies on Iraq. Sadr's speech is preceded by news broadcasts of President Bush discussing investigations into the Abu Ghraib prison scandal (Figure 
4.20). Sadr's speech opens with a series of questions to his congregation that counter Bush's claims of American moral superiority: "Has America saved us from the Baathists? [...] Who can trust America? Who can trust the biggest tyrant?" These questions are followed by a series of close-ups of people in attendance that range from middle-aged men to adolescent boys listening to Sadr's words sitting cross-legged. Longley's camera descends to the level of his followers as he depicts Sadr from a low angle explaining the brutal consequences that traitors to his leadership shall endure: "You saw what became of the spies, who informed on holy warriors in Sadr City, in Baghdad: They were hanged from the electricity poles!' (Figure 4.21) Longley positions his camera amidst Sadr's audience rather than on the sidelines. He does not simply observe the events before his camera's lens but performs an implicit commentary on the propagandist substance of both Bush's and Sadr's speeches through editing choices and variances in shot angles and subject framings.

\section{III: Insurgency Agency - The Blood of My Brother}

Berends' The Blood of My Brother subverts claims that theorists like Baudrillard have made about the war in Iraq, that, like the first Gulf war, the war in Iraq is just another "non-event," an event that has been launched into the realm of simulation and virtuality via the proliferation of war images. Baudrillard claimed that in the first Gulf War, viewers never saw the 'real' war, but witnessed a war that consisted of pure media speculation. The media event of the Gulf war featured talking head commentators like Dan Rather and Tom Brokaw reporting on the mission within the safe confines of their network studios, often broadcasting Precision Guided Missile (aka "Smart Bombs") video imagery making 
their targets, negating the representation of actual physical combat. This was the effect of "Annex Foxtrot" document that the Pentagon created to prevent news journalist from reporting from the front-lines of the conflict, forcing media representatives to gather information about the war exclusively through military officials. Baudrillard states: "War has not escaped this virtualization which is like a surgical operation, the aim of which is to present a face-lifted war, the cosmetically treated spectre of its death, and its even more deceptive televisual subterfuge." ${ }^{121}$ And later, in his last book, The Intelligence of Evil or the Lucidity Pact, Baudrillard argues that the "War on Terror" has "[become] an enormous special effect; cinema becomes the paradigm of warfare, and we imagine it as 'real,' whereas it is merely the mirror of its cinematic being."122 The notion of a "face-lifted war," a war that has become one massive "special effect," is what Berend's film criticizes - the war in Iraq is not a mere special effect or an illusion since it involves the very real death and suffering of people that experience the harsh realities of occupation regularly. Berends' film suggests that there is a way out of virtualization, unlike what Baudrillard has suggested. The Blood of My Brother allows viewers to witness the war from behind enemy lines, identifying with Iraqis instead of American soldiers. The film presents viewers with an alternative perspective into the war in Iraq that is highly critical of America's war machine.

Sontag has implicitly criticized Baudrillard's nihilistic belief that images have ultimately fractured our connection to reality:

\footnotetext{
${ }^{121}$ Jean Baudrillard, "The Gulf War Did Not Take Place," in Jean Baudrillard: Selected Writings, Trans. Mark Poster (Stanford, CA: Stanford University Press, 2001), 234.

122 Jean Baudrillard, The Intelligence of Evil or the Lucidity Pact, (Oxford :Berg Publishing, 2005$) ; 124$.
} 
To speak of reality becoming a spectacle is a breathtaking provincialism. It universalizes the viewing habits of a small, educated population living in the rich part of the world, [and] assumes that everyone is a spectator. It suggests, perversely, unseriously, that there is no real suffering in the world. ${ }^{123}$

The Blood of My Brother visualizes Sontag's criticisms of the Baudrillardian school of thought on the eradication of reality by images. The film is an exposé on the human confusion, frustration, and suffering of the Iraqi people, providing an "insider's" view into civilian and insurgent activities in a war zone. The Blood of My Brother conveys the harsh realities of living under occupation through its candid imagery of Iraqis dealing with war. Baudrillard's theories of reality and images is an argument Sontag had once shared but has now revised: "In the first of the six essays in On Photography (1977), I argued that while an event known through photographs certainly becomes more real than it would have been had one never seen the photographs, after repeated exposure it also becomes less real." 124 Sontag now contends that "[s]omething becomes real by being photographed to those who are elsewhere," and that images "bore witness to the real." ${ }^{125}$ But what does this say about our current digital image culture? Sontag makes brief reference to digital images in her book and insists that "fiddling with pictures long antedates the era of digital photography and Photoshop manipulations: it has always been possible for a photograph to mispresent." ${ }^{126}$ Furstenau states, "[h]ow the digital image differs [from photography] is not entirely clear." ${ }^{127}$ Digital images, then, are not any more of an abstraction from the real world than photography. Both modes of image-making process and isolate specific

\footnotetext{
${ }^{123}$ Sontag, Regarding the Pain of Others, 98-99.

${ }^{124}$ Ibid., 105.

${ }^{125}$ Ibid., 19,23 .

${ }^{126}$ Ibid., 41.

${ }^{127}$ Furstenau, "The Ethics of Seeing: Susan Sontag and Visual Culture Studies," 94.
} 
objects and subjects from the real world within the camera's framing. The digital image in The Blood of My Brother is utilized to make serious claims about the reality of the Iraq War behind enemy lines, giving exclusive agency to Iraqis to speak about their experiences.

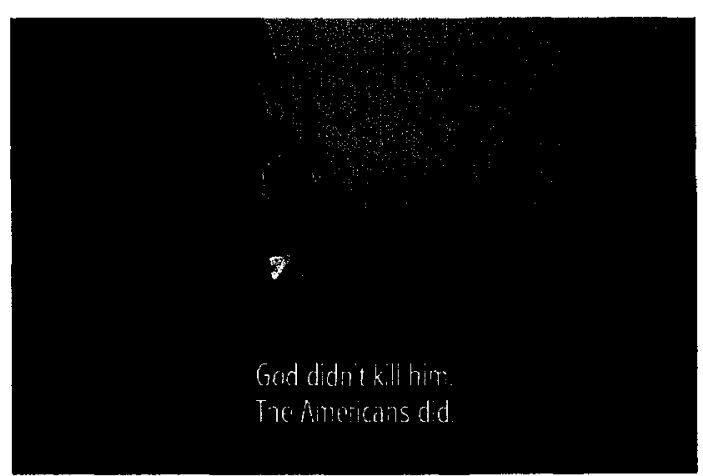

Figure 4.22 The Blood of My Brother (Andrew Berends, 2005)

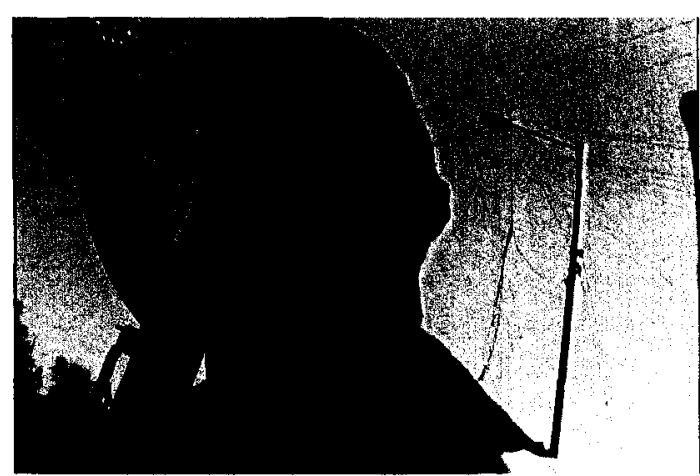

Figure 4.23 The Blood of My Brother

The Blood of My Brother asks its viewers to make important judgements and determinations about the reality it captures. Berends' film allows viewers to access the war from an opposing vantage point that is commonly absent in the Iraq war documentaries mentioned in Chapter Two and others such as Gunner Palace (Petra Epperlien and Michael Tucker, 2004) and Alive Day Memories: Home From Iraq (Jon Alpert and Ellen Goosenberg Kent, 2007). Like Iraq in Fragments, The Blood of My Brother positions itself within the collaborative history tradition by inviting the participation of the film's subjects to give testimonies to Berends' camera. Only a handful of American soldiers or Iraqi National Guard members are shown in the film. Berends' camera captures the daily struggles of Ibrahim, a young man who lost his brothers to the Americans, and the public activities of Iraqi insurgent groups. At one point, friends of Ibrahim's brother, Ra' ad, recount his last moments. Ibrahim addresses the nature of his 
brother's death, speaking to Berends off-frame: "Why do I have to be upset? It's destiny. It happened. He's gone." His next sentences are superimposed over an image of an American soldier loading his rifle from behind - "God didn't kill him. The Americans did." These images are soon contrasted with ones depicting masked men, followers of Moqtada, taking up arms and pronouncing their repugnance toward the American occupation. One of the masked men explains to the camera: "We've set up suicide attacks for Sayid Moqtada. Whoever touches him with bad intentions, we would all sacrifice ourselves for Sayid Moqtada." Throughout the film, occupation forces, by and large, remain "faceless" and silent, whereas Iraqis, either civilian or insurgent, are granted exclusive screen time to voice their beliefs, opinions, and perspectives on the war. ${ }^{128}$ It is also interesting to point out that on the film's DVD, a series of interviews with American soldiers in Iraq is included, revealing that a conscious decision was made to not include them in the film's final cut. Berends' adoption of the Iraqi point of view is also conveyed through his shooting style that evokes the 'amateur' war realism associated with early war photography, more specifically, Capa's D-Day photos.

The Blood of My Brother relies on the codes and conventions of early war photography to convey a heightened sense of immediacy within the film's digital images. Furstenau quotes Marita Sturken and Lisa Cartwright's claim that "“it has always been possible to 'fake' realism in photographs. Digital techniques have made it possible to

\footnotetext{
${ }^{128}$ There is one exception where Berends presents US military personnel searching an urban market for men who had been selling arms to insurgents. However, his camera focuses on the faces of the men the Americans interrogate more than the faces of American soldiers.
} 


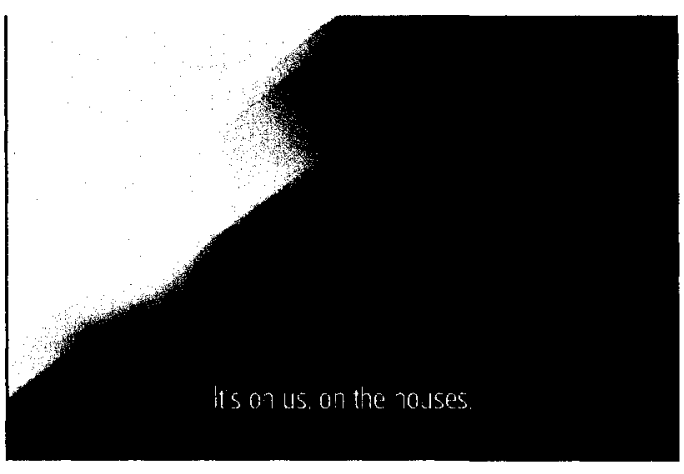

Figure 4.24 The Blood of My Brother build upon this ability to artificially construct realism." 129 Shortly following the scene described in the last paragraph, Berends' encounter of crossfire between insurgents and Allied forces recalls the motion blurs of Capa's Omaha Beach landing photographs (Figure 4.24). Berends navigates his way

through a series of locals, watching the arrival of a military helicopter while gun shots are heard off in the distance. Berends' shaky camera is mimetic in conveying the psychological and physical tension of being trapped in a hostile environment - jostling up and down, left and right, to recreate the feeling of being there amidst the mayhem. Berends' irregular movements recreate his spiral into distress but also imitate those of the clusters of children, men, and women who also caught fleeing within his ocular gaze. In this instance, the camera is not only representative of the nervousness of its operator, but also, of those caught within its gaze: the Iraqi people. Berends' camera imitates and conveys the chaotic feeling of combat. This imitative practice is used to help viewers identify with the sheer terror of living under occupation, to place audiences in the shoes of Iraqis. Michael Taussig writes in his book, Mimesis and Alterity: A Particular History of the Senses, on the function of mimesis, and the idea of imitation: "[T]he mimetic faculty is the rudiment of a former compulsion of persons to "become and behave like something

\footnotetext{
${ }^{129}$ Furstenau, "The Ethics of Seeing: Susan Sontag and Visual Culture Studies," 94.
} 
else.' The ability to mime, and mime well, in other words, is the capacity to Other." 130 This scene captures Berends' "capacity to Other" by his immediate proximity to the "action," recreated by his unstable camera, placing him in as much danger to American fire as those of the Iraqis caught on video around him. The immediacy of Berends' images recall Capa's famous dictum, "If your pictures aren't good enough, you aren't close enough." However, this is not to suggest that Berends' shooting style is a facsimile of Capa's, since Berends' camera sometimes identifies with the enemy.

Berends reverses the direction of Capa's camera gaze by enacting the look of the enemy, behind enemy lines. In contrast to The Blood of My Brother, Marilyn Young argues that American war films have historically negated the perspective of the enemy, opting for an imperialist or colonial gaze of the battlefield: "The camera always faces out against the enemy, or inward at the grievous wounds enemy fire causes." 131 This is certainly characteristic of films such as Black Hawk Down, Platoon (Oliver Stone, 1986) or We Were Soldiers (Randall Wallace, 2002) where screen time is largely devoted to depicting the pain and suffering of American soldiers versus a "faceless" enemy, largely hidden from the camera's view, ensuring identification is always with Americans (Letters From Iwo Jima being a recent exception to this rule). Identification with American soldiers is destabilized in the graphic novel, Pride of Baghdad (Brian K. Vaughan and Niko Henrichon, 2006), about the survival of a pride of lions that escape from the Baghdad Zoo in the early stages of the US's bombing campaign of 2003 . Focusing on

\footnotetext{
${ }^{130}$ Michael Taussig, Mimesis and Alterity: A Particular History of the Senses, (New York: Routledge, 1993); 19.

${ }^{131}$ Marilyn Young, "In the Combat Zone," in Hollywood and War: The Film Reader, ed. J. David Slocum, 316, (New York: Routledge, 2006).
} 


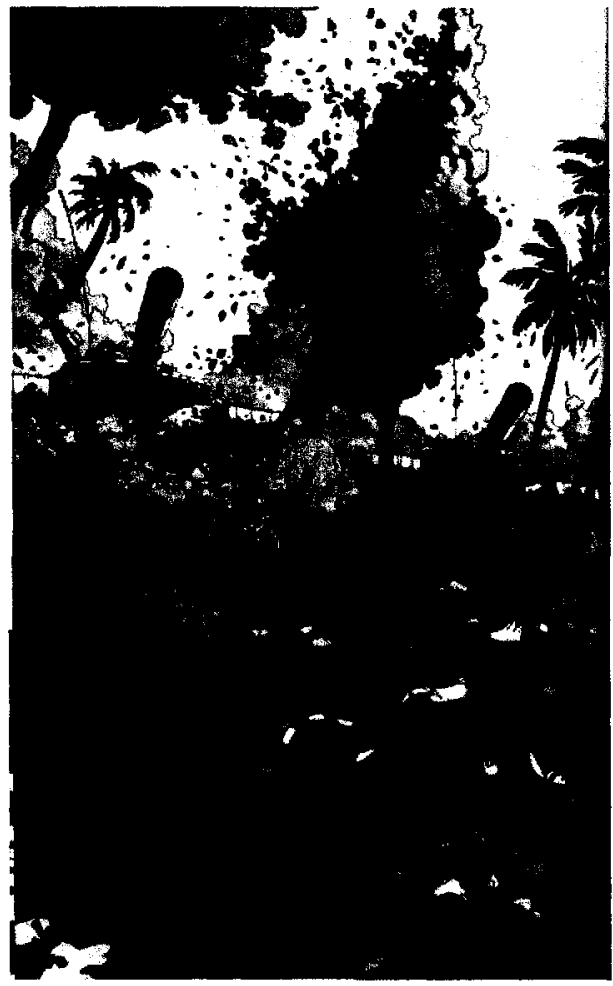

Figure 4.25 Pride of Baghdad (Brian K. Vaughan and Niko Henrichon, 2006)
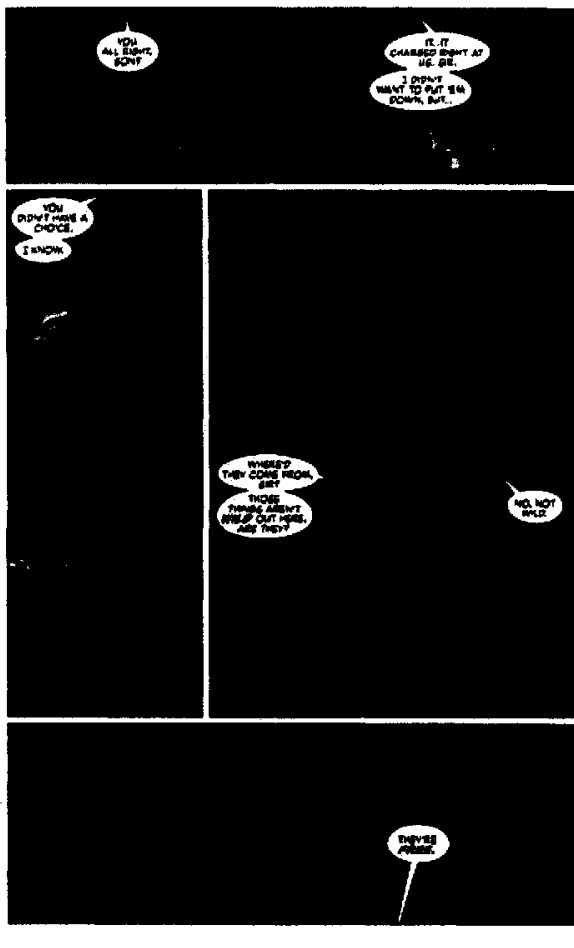

Figure 4.26 Pride of Baghdad

their struggle to survive in a war zone, the book represents the American military presence as primarily technological (tanks, jets) and refuses to represent them as human (Figure 4.25). And whenever American soldiers are featured, they are depicted from behind or drawn with blank faces (Figure 4.26).

In The Blood of My Brother, the enemies' gaze is most prominent during a rally for the Mehdi Army in the streets of Baghdad. Berends records the crowds chanting, "Long-live al-Sadr. American and the governing nations are infidels." Shot over-theshoulder of Ayatollah Sistani, one of Sadr's followers, Berends captures Sistani's speech of hope and triumph over American forces to a crowded street of eager listeners (Figure 


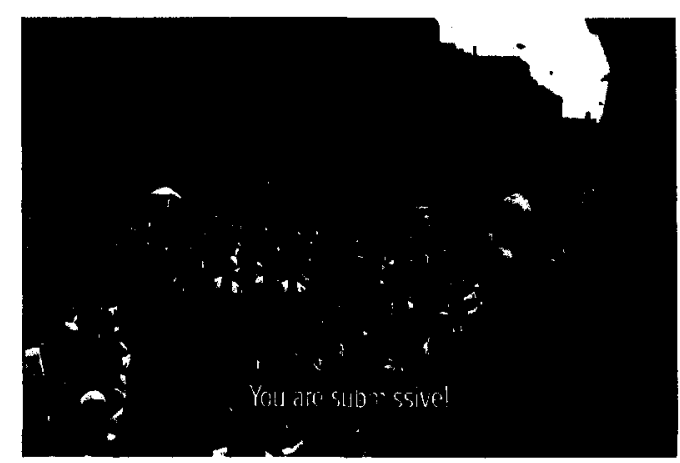

Figure 4.27 The Blood of My Brother

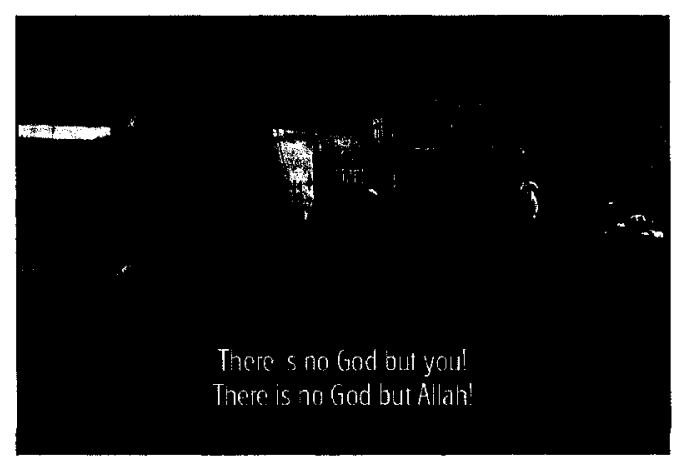

Figure 4.28 The Blood of My Brother

4.27). Shortly thereafter, a Sistani-led demonstration in Najaf is shortly met with force by Iraqi police. The crowd moves steadily forward towards the police as an explosion of gunfire is heard, dispersing the crowd instantly. Berends' camera recedes from the site of confrontation momentarily, then moves towards a man screaming in pain reducing the distance between camera and subject, surrounded by pairs of shoes and sandals that once belonged to those of the crowd (Figure 4.28). The man cries out: "There is no God but you! There is no God but Allah!" In this privileged moment, Berends risks his own safety to capture the faces and voices of who are a part of the resistance to the American presence in Iraq, reminding viewers that the insurgency is human, giving visibility to the pain and suffering of others.

The Blood of My Brother resists the imperialist or colonial camera gaze generally associated with American war films and also with the Iraq war films discussed in Chapter Two, which film the war from the perspective of American soldiers, ignoring those of the Other. The Blood of My Brother and Iraq in Fragments represent a sub-group of Iraq war 
films that return viewers to the reality of war on the other side. Zizek states that these kinds of revisionist texts represent a larger psychological desire to "return to the Real":

This means that the dialectic of semblance and Real cannot be reduced to the rather elementary fact that the virtualization of our daily lives, the experience that we are living more and more in an artificially constructed universe, gives rise to an irresistible urge to 'return to the Real,' to regain firm ground in some 'real reality.' 132

The "virtualization of our daily lives" has become an increasingly popular way to describe how contemporary warfare has cataclysmically altered our sense of reality in the twentyfirst century. This imperialist or colonial camera gaze associated with American war films is often tied to technological ways of seeing. This way of seeing war is exemplified in The War Tapes and Occupation: Dreamland. In these films, the viewer's perspective of events is often filtered through a military technology, often through night vision. The Blood of My Brother and Iraq in Fragments may filter the spectator's gaze through digital video, but it is never akin to seeing through military tools of vision. Analyzing the ways in which night raids are represented in Occupation: Dreamland and The Blood of My Brother will illustrate this contrast of representation.

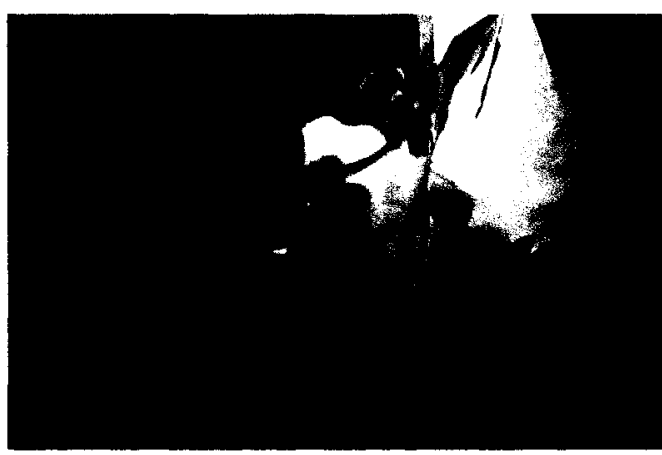

Figure 4.29 The Blood of My Brother

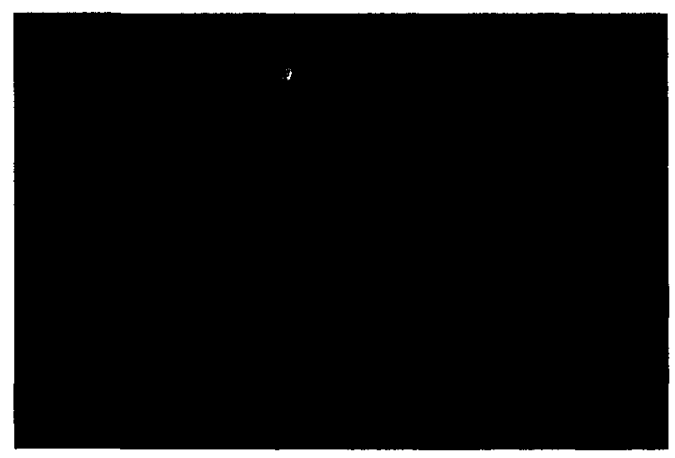

Figure 4.30 The Blood of My Brother

${ }^{132}$ Zizek, "Passions of the Real, Passions of Semblance," 93. 
As discussed in Chapter Two, Occupation: Dreamland adopts a highly mediated gaze via night vision, simulating the soldiers' visual experience as they are also seen with their night vision goggles over their eyes. The night raid presented in The Blood of My Brother never features this technological rendering of events. Berends never opts for night vision when following a patrol of men entering a dimly lit house searching for evidence of illegal activity, despite the poor lighting conditions of shooting digital video at night without artificial lighting equipment. Berends' film lacks full coverage of the endeavour, framing events with swift hand-held camera movements, canted angles, and underexposed shots. Instead of artificially illuminating the darkened corners of the home through night vision, Berends utilizes shadows to convey the confusion and disturbance of the home's inhabitants to the viewer. A shot of a pair of hands held together with plastic ties and close-ups of blind-folded men present the alienating and estranging aspects of this invasion (Figure 4.29 and Figure 4.30). Disillusionment is their reality of occupation, conveyed in the film through Berend's mimetic camera style. Berends' realist mode of address is also used to reveal the psychological and sociological implications of the American technological war machine in Iraq.

In a scene that features footage of a battle between Americans and insurgents, the ican presence in this case, is purely technological - technological in the sense that human soldiers are often absent from Berends' camera where American tanks and helicopters act as far superior substitutes to ground troopers. Again, the American presence in the film remains "faceless." In this scene, Berends is no longer with the insurgent cell, but is now amongst a group of curious onlookers. A boy peeks his head around the corner of a 


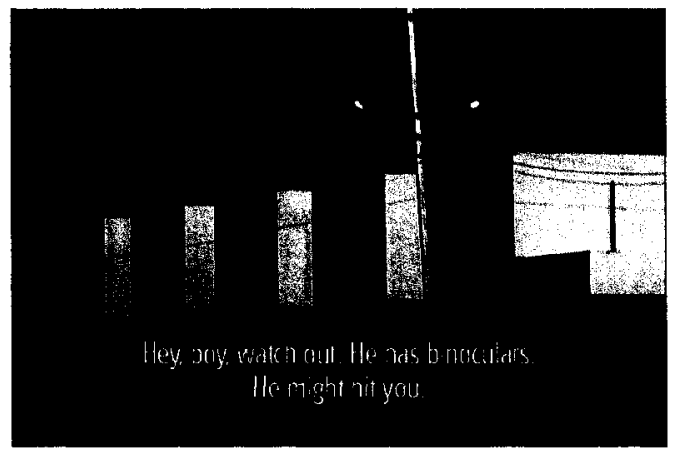

Figure 4.31 The Blood of My Brother building to get a glimpse of an American tank fast approaching, as an off-screen voice warns: "Hey. Boy. Watch out. He has binoculars. He might hit you." (Figure 4.31) This warning expresses a fear of the technological superiority of the American military. Huppauf quotes Ernst Junger's

comment that this is a fear of the "cold and dispassionate view of the artificial eye" of American military vision technology. ${ }^{133}$ With reference to what one helicopter pilot recounted about his experience during the Vietnam War, Tim Blackmore states: “One Cav soldier reports: 'Our tactics were speed and killing. We were always the aggressors. We took the initiative and would not hesitate to level a village at the slightest provocation."134 As mentioned before, Huppauf explains that this mode of "waging war at a distance" can be traced back to the introduction of aerial photography in WWI:

In photographs taken from a certain altitude, only objects of a certain minimum size will be represented; smaller objects, in particular human bodies, will not be there, and cannot be made visible even with magnifying glasses or through extreme enlargements. [...] Aerial photographs are symptoms of and at the same time forces in the process of changing the mode of perception by fusing pure aesthetic effects and highly functional military information. Their space is emptied of experience and moral content. ${ }^{135}$

Akin to Blackmore's soldier's testimony and Huppauf's observations of the dehumanizing implications of aerial war photography, the tank and the helicopter are technologies that reconfigure the battleground and empty it of "face-to-face" combat. Berends never grants

\footnotetext{
${ }^{133}$ Huppauf, "Experiences of Modern Warfare and the Crisis of Representation," 58.

${ }^{134}$ Tim Blackmore, War X: Human Extensions in Battlespace, (Toronto: University of Toronto, 2005); 112.
} 
the viewer the privilege of seeing as they, the Americans, see-preferring identification with the innocent

Films like The Blood of My Brother, Iraq in Fragments or docu-drama's like The Road to Guantanamo differentiate themselves from the 'norm' by engaging the experiences of the 'non-western' people. These films identify gaps left by films like The War Tapes, Occupation: Dreamland, and In the Valley of Elah in the complex historical discourse of the war in Iraq. Zimmerman argues that the increasing democratization of media coverage on the Iraq war (notably from Arabic based TV networks like Al Jazerra) characterizes a crucial shift in how we historicize events in the public domain: "This strategy suggests a participatory model of public media that shifts from making works for communities and, instead, proposes making works with communities that form around practices, contradictions and openings." ${ }^{, 136}$ All three films in this chapter are works made closely with the subjects within them, offering other accounts of the real war experience. And despite what postmodernists like Baudrillard say of the growing unreality of the contemporary world, these films and scholars like Sontag refuse this idea of the obliteration of meaning in images and reality.

\footnotetext{
135 Ibid., 60-61.

${ }^{136}$ Patricia R. Zimmerman, "Public Domains: Engaging Iraq Through Experimental Digitalities," 70.
} 


\title{
CONCLUSION
}

\section{Seeing Through the Fog and the Screens of War - Redacted}

\author{
Don't want to be an American idiot. \\ One nation controlled by the media. \\ Information age of hysteria. \\ It's calling out to idiot America.
}

“American Idiot," Green Day

The contemporary war film raises many problems, issues, and uncertainties to the ways in which war is represented in the post-9/11 period. And I've shown, the complications of narrativizing war evident in these films is nothing new. Similar issues have emerged since the early days of war photography. However, I did not want to oversimplify this historical relationship. These films have proven to be deeply influenced from early war photography aesthetics and techniques. They reflect new ways of circulating and transmitting contemporary war images beyond the front lines, but do keep in mind how images used to be disseminated. Cinema is only one source of information on this war amongst a multitude of other competing media. People now have a greater variety of options to access and assess information produced on the "War on Terror" or the war in Iraq by both professionals and "amateurs." Most of the films in this thesis have acknowledged, on a formal and aesthetic level, the various modes of digital technology that are available to those that seek to record, transmit, and circulate their experiences of war. The presence of other media within these films highlights the intricacies and complexities of representing war in the digital era, and will now turn to an examination of Brian De Palma's Redacted (2007) to help summarize what has been discussed throughout this thesis. 
Redacted is a far more poignant commentary and meditation on the ways in which war is mediated in the post-9/11 period than any other film discussed within this work. Redacted is useful to address now since it summarizes many of the issues and themes noted throughout this thesis. Redacted has been compared to De Palma's 1989 Vietnam War picture, Casualties of War, in numerous press reviews and features. The story of Casualties of War is a dramatization of the real-life event of US soldiers raping and torturing a young female civilian during the Vietnam war. In Redacted, US soldiers rape and murder a 14 year-old Iraqi girl and her family that was also inspired by a real event. However, what separates Redacted from Casualties of War is how De Palma chose to shoot and assemble Redacted's fictionalized narrative. In his latest film, De Palma utilizes a multimedia, cinema verite narrative form that consists of mock video blogs, a French documentary, surveillance tapes, digital camcorder images, Arab news reports, and a concluding montage of "redacted" photographs of real Iraqi casualties - featuring a much more diverse and dynamic array of media materials than any other film discussed in Chapters Two or Three. ${ }^{137}$

In her review of Redacted, Stephanie Zacharek explains that the film's multimedia mode of address "is a metaphor for the struggle to make sense out of [information]

\footnotetext{
${ }^{137}$ There has been much speculation concerning the black inked faces of the film's concluding photo montage featuring actual maimed, tortured, and disfigured Iraqis bodies. In a press conference at the New York Film Festival in the fall of 2007, De Palma claims that the producers from Magnolia Pictures, Mark Cuban's company that financed the film, "redacted" the film itself because Cuban was offended by the raw images and opted to ink out the faces of the people featured in the montage. Eamonn Bowles, president of Magnolia Pictures, denies De Palma's accusations and claims that this action was carried out due to legal concerns to avoid any lawsuits that family of the displayed victims could seek for emotional damage. See http://www.youtube.com/watch?v=lDNWXgM9F70 for footage of the festival incident.
} 


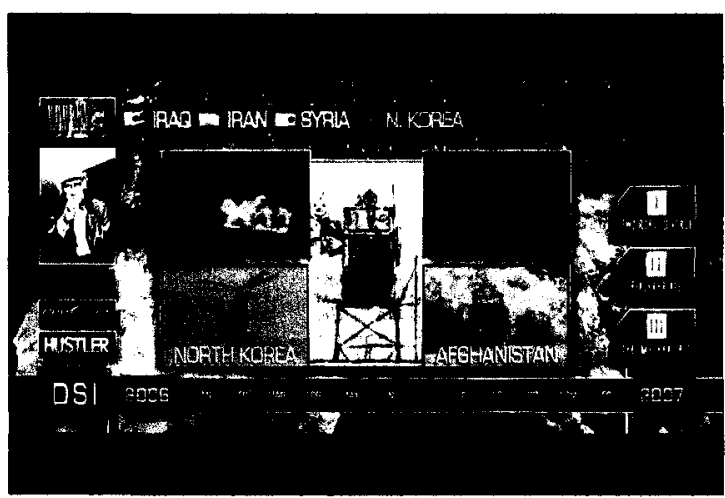

Figure 5.1 Southland Tales (Richard Kelly, 2006)

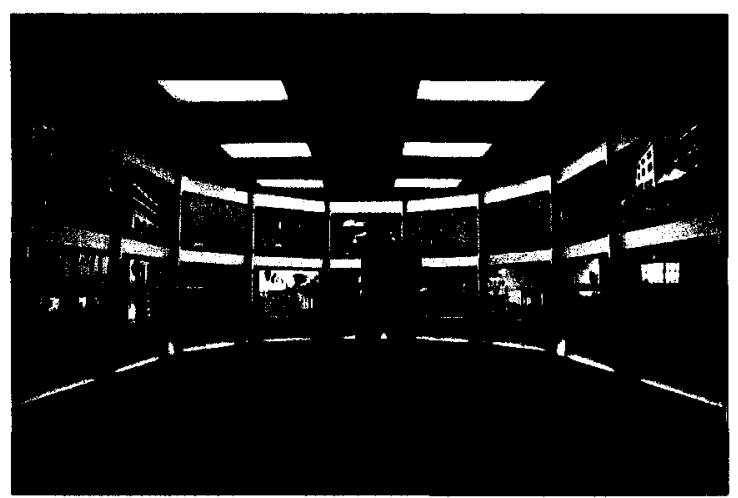

Figure 5.2 Southland Tales

chaos." ${ }^{138}$ Similarly, Southland Tales (Richard Kelly, 2006) employs a complex

multimedia narrative guise mirrored by an even more convoluted and dizzying narrative story. In his blog, "The Pinocchio Theory," Steven Shaviro states:

Southland Tales's visual flow is... that of these post-cinematic media that play such a role within it. Properly cinematic images are intermixed with a barrage of home video footage, internet and cable-TV news feeds, commercials, simulated CGI environments, and especially sequences in which the film's characters are watching all of the above on multiple computer windows or screens. The compositional logic of Southland Tales is paratactic and additive, having little to do with conventional film syntax. ${ }^{139}$

Films like Redacted and Southland Tales make serious efforts to envision a multimedia viewing experience that correlates with the spectator's mediated world that exists outside of the theatre space (Figure 5.1 and Figure 5.2). De Palma has stated that his inspiration for reproducing the multimedia look for the film came from his experience of the massive circulation of images while researching the story of the real incident through the Internet:

....in the process of researching [Redacted], I found all these unique ways of expressing what was going on over in Iraq that were on the internet.

\footnotetext{
${ }^{138}$ Stephanie Zacharek, "'Redacted'," Salon.com (November 16, 2007). http://www.salon.com/ent/movies/review/2007/11/16/redacted/ (accessed April 26, 2008).

${ }^{139}$ Steven Shaviro, "Southland Tales," The Pinocchio Theory (December 10, 2007). http://www.shaviro.com/Blog/?p=611 (accessed May 13, 2008).
} 
Whether they were news stories, or blogs, or postings on YouTube, montages of casualties, well this is the way to tell this story. ${ }^{140}$

The simulation of multimedia images for the production of Redacted reflects how people today (and not only professional journalists any more) are producing, circulating and consuming information on the war across different media. Philip M. Taylor argues that the use of the Internet in the "'War' Against Terrorism" has been exemplary of an important transformation in who produces 'news-worthy' information:

If the 'War' Against Terrorism is... an ideological struggle for hearts and minds between two competing ways of life, between two competing 'realities', the Internet provides a unique battle space in which information and disinformation are front-line weapons and where 'citizen journalists' become key participants. ${ }^{141}$

Taylor's notion of citizens adopting the role of journalists reworks the professional model of conventional news reporting standards. "[T]he Internet as an interactive medium of communications by individuals with access to it," Taylor argues. "[It] redefines not just the way information flows within and beyond an area of conflict but it also 'demassifies' the traditional monopolistic role of journalists as observers of other people's miseries."142 The people who are suffering these miseries can now take more control over the representation of their experiences than before. Taylor's assertions are certainly applicable to the "soldier-turned-journalists" or the "amateur auteurs" featured in The War Tapes, In the Valley of Elah or the simulation of non-professional reporting in Occupation: Dreamland and The Blood of My Brother.

\footnotetext{
140 "Brian De Palma: Reasons for making Redacted," YouTube (Posted October 9, 2007) http://www.youtube.com/watch?v=52dC14Od5Ks (accessed April 18, 2008).

${ }^{141}$ Philip M. Taylor, "The World Wide Web Goes to War: From Kosovo to the 'War' Against Terrorism," in Web Studies, eds. David Gauntlett and Ross Horsley, (London: Arnold, 2004): 241.

${ }^{142}$ Ibid., 235.
} 
Taylor also suggests that this move to "de-professionalize" news media or dethrone journalists from their privileged positions has been, by and large, made possible because of the Internet. "[T]he real point," Taylor suggests, "is that anyone with such equipment could also transmit their news, comment and pictures to a global audience, bypassing the traditional mass media." "143 "Terminal identity" is what Scott Bukatman calls this kind of interaction with the multimedia universe - a term derived from Baudrillard's analogy that the postmodern subject "has become a 'terminal of multiple networks"' and William S. Burroughs' description in Nova Express (1964) that "[t]he entire planet is being developed into terminal identity...". 144 "Terminal identity," as Bukatman defines it, "[is] an unmistakably doubled articulation in which we find both the end of the subject and a new subjectivity constructed at the computer station or television screen." 145 Despite Bukatman's exclusive use of the term for describing the subjects in what he calls "terminal identity fictions" (including the writings of Donna Haraway, the fiction of Philip K. Dick and William Gibson, and films like The Man Who Fell to Earth (Nicholas Roeg, 1976)), the spectator's viewing experience of Redacted is akin to his analogy. The film unravels as a media collage where we, the viewers, are called upon to witness the film's events through multiple electronic screens.

"A familiar theme in the criticism of the real-time war," Paul Rutherford insists, "was the lot of the overwhelmed viewers, caught in a media storm and unable to find their

\footnotetext{
${ }^{143}$ Ibid., 232.

${ }^{144}$ Scott Bukatman, Terminal Identity: The Virtual Subject in Postmodern Science Fiction, (Durham: Duke University Press, 1993): 2, 9.

${ }^{145}$ Ibid., 9.
} 
bearings." ${ }^{146}$ Rutherford criticizes this belief that people felt bewildered from the proliferation of news on the war and that it actually underestimates the capacity of viewers to work through information conveyed in the media. Rutherford explains that "adults in North America are veterans of innumerable media storms, the result of growing up in the age of unlimited media."147 In reference to what Todd Gitlin calls, "styles of navigation," Rutherford states:

[North Americans] had to develop ... 'styles of navigation' to cope with the torrent of advertising, entertainment, and news that has always surrounded their lives.... The skills born of the experience of understanding ads or sports, music or movies, the financial pages and the political news - these skills they could readily apply to war coverage. ${ }^{148}$

As "overwhelmed" as viewers may have felt when first encountering the large amount of visual evidence disseminated on the War in Iraq since the "Shock and Awe" campaign of 2003 , the skills required to better understand and comprehend the onslaught of war news was in place, the result of past encounters with television, newspapers, cinema, and the Internet. De Palma employs various media devices to simulate the navigations audiences are forced to make when "[swimming] through the sea of communications."149

Viewers of Redacted are quickly forced to adopt an active spectatorship with the introduction of "A War Diary by PFC. Angel Salazar," the film's first mode of address that features the video diary of an aspiring USC film student. As his camcorder gradually zooms in on the members of his squad, "the Mustangs", Salazar (Izzy Diaz) explains the difference between bearing witness to and being present in his images, evoking the

\footnotetext{
${ }^{146}$ Rutherford, Weapons of Mass Persuasion: Marketing the War Against Iraq, 111.

${ }^{147}$ Ibid., 111.

${ }^{148}$ Ibid., 111.

${ }^{149}$ Ibid., 111.
} 


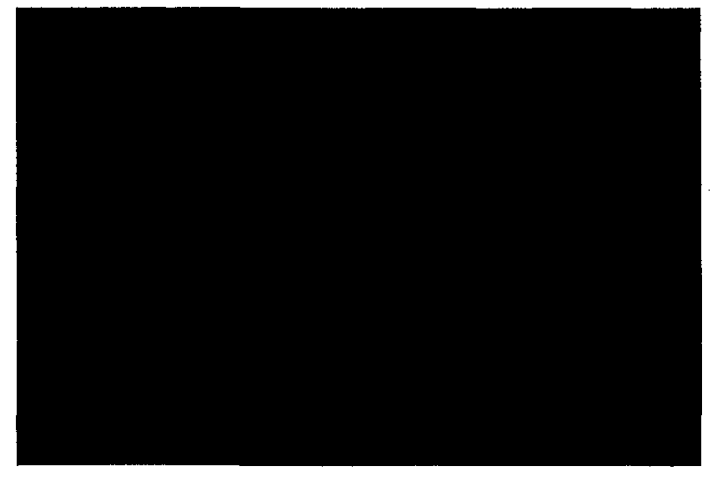

Figure 5.3 Redacted (Brian De Palma, 2007)

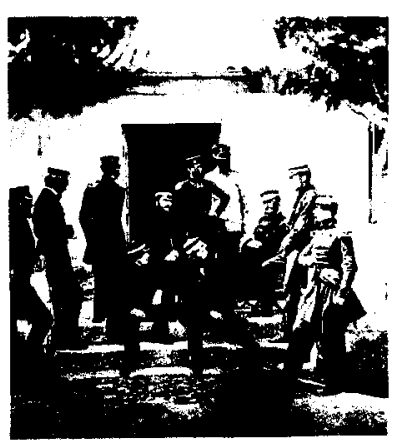

Figure 5.4 The Staff of Headquarters (Roger Fenton, 1855)

conundrum of distance discussed in the context of the telephone and cell phone in Chapter 2: "What I can't convey via this video journal is the incredible heat and the local smells." The soldier has "the Mustangs" huddle together and smile for his camcorder, "rendering the war as a dignified all-male group outing," mirroring the composition of military officers that appear in several of Fenton's images such as The Staff of Headquarters (1855) (Figure 5.3 and Figure 5.4) ${ }^{150}$

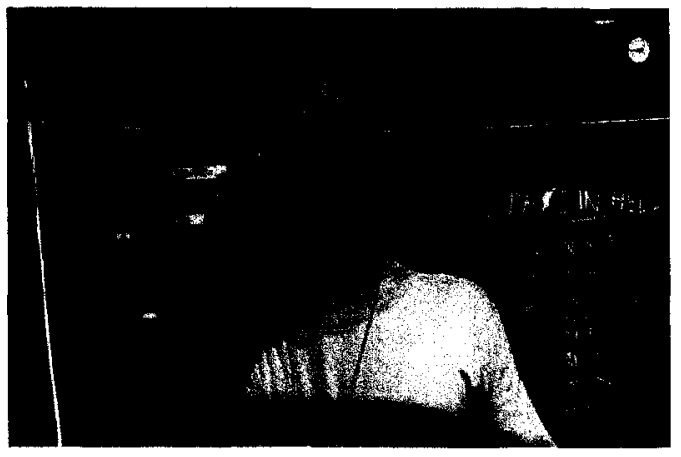

Figure 5.5 Redacted

This initial simplistic representation of war is shortly abandoned and explicitly criticized in the film. As Salazar's camera jostles up and down floating through the rows of beds in "Camp California," another soldier in Salazar's squad, Lawyer McCoy (Rob Devaney) explains to the men that the first casualty of this conflict is going to be "the truth," summoning Senator Hiram

${ }^{150}$ Sontag, Regarding the Pain of Others, 50. 
Johnson's remark in 1917 that "the first casualty when war comes is truth." (Figure 5.5) ${ }^{151}$ However, many critics have explained that Redacted is not really about the redaction or censorship of information by the media or by the American government at all, but that it is more concerned with the state of how the war is mediated and circulated along various media networks. If the film is more about the processes of media and war then about the censorship of 'sensitive' information, then does McCoy's allegations have anything to do with the act of redaction? McCoy's plea is explicitly performed for the satisfaction of Salazar's video journal and could, then, be interpreted as a reminder to viewers of the ways in which we construct truth and understanding about the Iraq War via our careful engagement with various media.

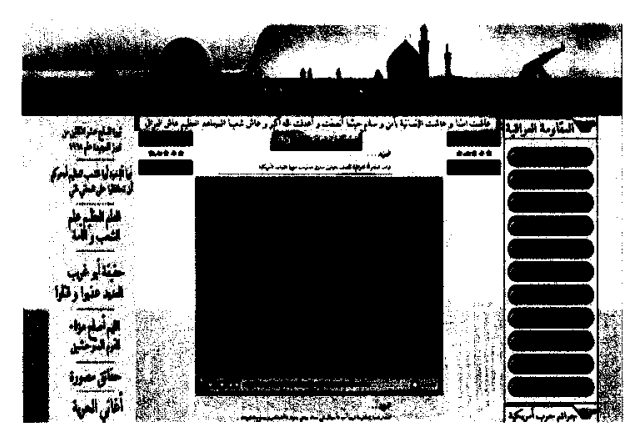

Figure 5.6 Redacted

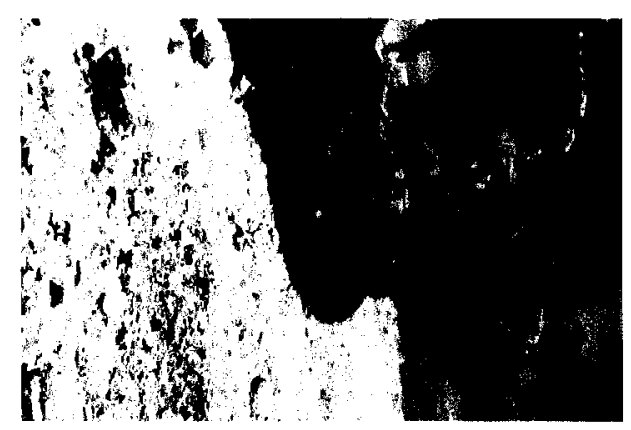

Figure 5.7 Redacted

After McCoy's statement fails to be rewarded with the applause of his comrades, Salazar turns the camera on himself and warns his audience: "Don't expect some Hollywood action flick," adding that his video will have "no logical narrative to help make sense of it." Although the film's narrative may not unfold in the linear manner typical of Hollywood cinema, the editing strategy of Redacted is, in fact, like "some

\footnotetext{
${ }^{151}$ Roeder Jr., "War as a Way of Seeing," 69.
} 
Hollywood action flick." The film abides by a 'cause-effect' logic, organizing its various candid images in a dramatic arc that is similar to how the narratives of Occupation:

Dreamland and The Road to Guantánamo are structured (see Chapter Two and Three).

One scene involving a deadly encounter with an IED illustrates the conventional nature of Redacted. Master Sergeant Sweet (Ty Jones) confronts a member of his infantry, Reno Flake (Patrick Carroll) about the dangers of accepting food from locals. Sweet warns: "You chow down on anything that these mother fucking ragheads give you, it's like swallowing an IED." Later, an online video shot in night vision from a Jihad website depicts a young boy cautiously surveying piles of rubble and junk with an unknown object in hand, looking back to the camera operator for authorization of the object's placement (Figure 5.6). Returning to Salazar's video diary, Flake's closet friend, B.B. Rush (Daniel Stewart Sherman) carelessly travels near the debris and is quickly called out by Sgt. Sweet. Sweet directs Rush to be more cautious where he decides to plant his feet and sets up his own ironic fate: "We came here in one piece, you bet your ass we are going to leave here in one piece." Falling onto an old armchair, Sweet regains his balance and is literally blown to pieces (Figure 5.7). Our gaze is returned to the website, only to find a now distanced video of the deadly incident. Shot from a similar camera position of the previous online video, Sweet is shown again being killed as an off-screen voice chants, “Allah." De Palma's bookend arrangement of Salazar's video between the website videos leads viewers to the conclusion that the boy had placed an IED near the piece of furniture, only to be detonated by a nearby operator. The editing of this scene performs the function of Rutherford's identification of "styles of navigation" - by juxtaposing viral video footage and Salazar's digital images of the same event, De Palma provides the viewer with 
greater coverage of the event by employing heavily mediated vantage points that viewers are likely to be familiar with in their own encounters with the images of Iraq.

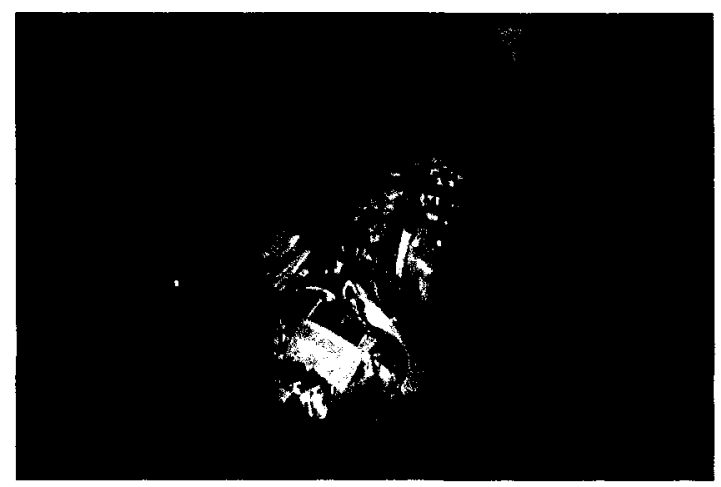

Figure 5.8 Redacted

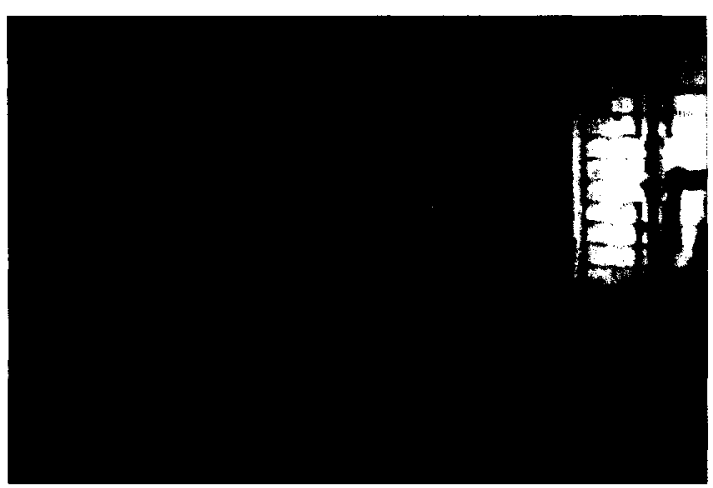

Figure 5.9 Redacted

Redacted's main concern is to also present its audience with the visceral brutality of the rape of a young Iraqi girl and the subsequent murders of her and her family. Many reviews of the film including Zacharek's have stated that the rape scene triggers "our impulse... to look away," but that this is easier said than done. Zacharek states that De Palma "has always been interested in collapsing the distance between viewer and subject," often making viewers uncomfortable and yet curious about what they are witnessing onscreen. ${ }^{152}$ McCoy's attempts to stop Flake and Rush from wreaking their demented and misdirected revenge on the young girl and her family for Sweet's death are recorded by Salazar's camera (Figure 5.8 and Figure 5.9). McCoy confronts Salazar's decision to remain and continue to document the event: "What's your excuse Sally? For why you're taking part of this?" Salazar replies: "I'm the fly on the wall." This statement brings about many connotations, mainly the unsolved issue of documentary ethics and the

152 Zacharek, “'Redacted"”. 
question of where filmmakers should draw the line when it comes to intervening in events they portray on-screen. Salazar enters the house and records Flake's and Rush's descent into madness as they proceed to take hold of their victim. The stylistic technique and context of the scene conjures up similar raid scenes discussed in this thesis with the dehumanizing affect of night vision in The War Tapes, and Occupation: Dreamland. Furthermore, Salazar's simple "observational" role in events is compromised when Rush tells Salazar to participate in the event by holding the girl steady as he abuses her while Salazar keeps the camera rolling. This is an implicit issue confronting Berends in The Blood of My Brother when he decides to move his camera closer to the subject in extreme pain as opposed to shutting it off and helping him or Mike's desire to photograph his personal trauma in In the Valley of Elah. So, what is it about the nature of these warrelated traumas that compels these "amateur auteurs" to record them?

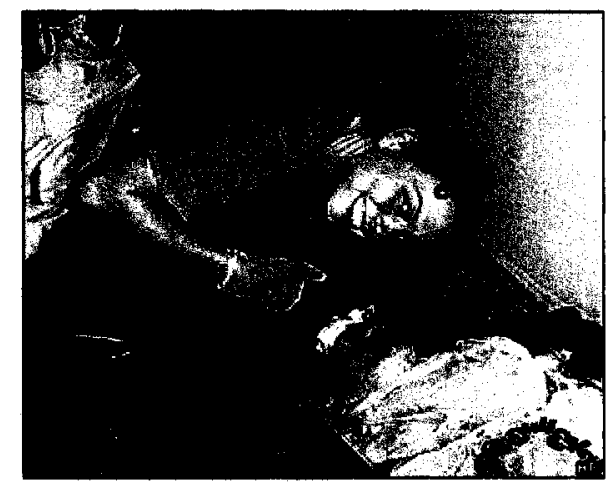

Figure 5.10 Sarah Harman, 2003

Anticipating the release of his new film, Standard Operating Procedure (2008), later this year, Errol Morris and Philip Gourevitch, co-author with Morris of the film's companion book, discuss the Abu Ghraib prison scandal in an article for The New Yorker. The article investigates the role that the notorious photographs played in the prosecution of

former US marine, Sabrina Harman. Harman discusses the nature of her famous "thumbsup" gesture in many of the images she is featured in, including one where she hovers above a corpse smiling and giving her usual sign of approval for the camera. Harman also 
regularly took photos of other questionable activities that occurred at the prison. Gourevitch and Morris state that "to Harman it was a way of deflecting her own humiliation in the transaction, by acting as a spectator." 153 She is quoted explaining why she always wrote letters home and roamed the halls of Abu Ghraib with a camera in hand:

'Maybe writing home was a release, to help me forget about what was happening,... I put everything down on paper that I was thinking. And if it weren't for those letters, I don't think I could even tell you anything that went on. That's the only way I can remember things, is letters and photos. ${ }^{, 154}$

Gourevitch and Morris add that "Harman seemed to conceive of memory as an external storage device. By downloading her impressions to a document, she could clear them from her mind and transform reality into an artifact." 155 The transformation of what they identify as "reality into an artifact" is what is happening in Redacted, and also in the films analyzed in this thesis. Harman's confession that the only way she remembers what happened through letters and photos reinforces this notion of transference; instead of internalizing trauma, it is externalized as objects of documentation. These are trauma artifacts that are meant to be shared or transmitted to others. As Salazar reminds McCoy, his reason for recording the rape is so that he can get into film school. Caruth reminds us that "the experience of trauma... is the repeated confrontation with the necessity and impossibility of grasping the threat to one's own life."156 Representation is, then, inextricably tied to the traumatic experience. This has been demonstrated in these films by their explicit focus on the new modes of communication that construct narratives of the

\footnotetext{
${ }^{153}$ Philip Gourevitch and Errol Morris, "Annals of War: The Woman Behind the Camera at Abu Ghraib," The New Yorker (March 24, 2008): 54.

${ }^{154}$ Ibid., 54.

${ }^{155}$ Ibid., 54.

${ }^{156}$ Cathy Caruth, Unclaimed Experience: Trauma, Narrative, and History, 62.
} 
new war. Whether it is a photograph used to help people comprehend the Battle of Iwo Jima in Flags of Our Fathers, or soldiers shooting their own experiences in The War Tapes, or the various media imagery utilized in The Road to Guantánamo and Redacted, the contemporary war film has continually represented how images affect and help shape our perceptions of modern warfare, and how the photographic apparatus (which includes digital) redefines and expands our relationships and interactions with media images and reality.

This project has specifically dealt with war films that reflect our complex interaction, understanding, and experience of the War on Terror, with special attention given to the war in Iraq. These films confront the viewer with the ways in which the combat experience in Iraq is increasingly mediated - through military equipment, Mini DV camcorders, camera phones, broadcast news, internet blogs and more. Like the "living room war" of Vietnam, or the war of media speculation in the Gulf in 1991, the "War on Terror" is being fought on two fronts - on the ground and in the media. This is not to suggest that the "War on Terror" is experienced in the very same way as previous wars, despite the affinities they share. New relationships have been formed between new media, soldiers, and civilians. The ways in which information on the war is disseminated has dramatically altered our sense and knowledge of what is happening over there, insisting on new ways to produce knowledge and learn about the tragic world we live in. 


\section{BIBLIOGRAPHY}

Batchen, Geoffrey. "Photogenics." In The Photography Reader, ed. Liz West, 228-239. New York: Routledge, 2003.

Baudrillard, Jean. "The Gulf War Did Not Take Place," In Jean Baudrillard: Selected Writings, Trans. Mark Poster, 231-253. Stanford, CA: Stanford University Press, 2001.

. Simulacra and Simulation. Ann Arbour: University of Michigan Press, 1994.

The Intelligence of Evil or the Lucidity Pact. New York: Berg, 2005.

The Spirit of Terrorism and Other Essays. New York: Verso, 2003.

Bazin, André. "The Ontology of the Photographic Image." In Film Theory and Criticism: Introductory Readings, $5^{\text {th }}$ Edition, ed. Leo Braudy and Marshall Cohen. New York: Oxford University Press, 1999.

Blackmore, Tim. War X: Human Extensions in Battlespace. Toronto: University of Toronto, 2005.

Braudy, Leo. "Flags of Our Fathers/Letters From Iwo Jima." Film Quarterly 4 (2007): 16-23.

"Brian De Palma Interrupted at NY Film Festival Press Conference."; YouTube (October 9, 2007) Available from http://www.youtube.com/watch?v=lDNWXgM9F70; Accessed April 18,2008.

"Brian De Palma: Reasons for making Redacted."; YouTube (October 9, 2007) Available from http://www.youtube.com/watch?v=52dC14Od5Ks; Accessed April $18,2008$.

Brothers, Caroline. War and Photography: A Cultural History. New York: Routledge, 1997.

Bukatman, Scott. Terminal Identity: The Virtual Subject in Postmodern Science Fiction. Durham: Duke University Press, 1993.

Carruthers, Susan L. "Say Cheese!: Operation Iraqi Freedom on Film" Cineaste 32, no. 1 (Winter 2006): 30-36.

Caruth, Cathy. Unclaimed Experience Trauma, Narrative and History. Baltimore: John Hopkins University Press, 1996. 
Chan, Evans. "War and Images.” Film International 5, (2003): 10-23.

Currie, Gregory. "Visible Traces: Documentary and the Contents of Photographs." In Philosophy of Film and Motion Picture: An Anthology, eds. Noël Carroll and Jinhee Choi, 141-153. Malden: Blackwell, 2006.

Danchev, Alex. "War Stories." The Journal of Military History, 69, no. 1 (January 2005): 211-215.

Davis, Joshua. "“If We Run out of Batteries, This War is Screwed."; Wired (June 2003) Available from http://www.wired.com/wired/archive/11.06/battlefield.html; Accessed May 15, 2008.

Derrida, Jacques. Specters of Marx: The State of the Debt, the Work of Mourning, and the New International. New York: Routledge, 1994.

Ebiri, Bilge. "The Ravages of War and Occupation: An Interview with James Longley," Cineaste, 32, no. 1 (Winter 2006): 38-41.

Elley, Derek. "Redacted,"; Variety (August 31, 2007) Available from http://www.variety.com/review/VE1117934538.html?categoryid=31\&cs=1; Accessed April 23, 2008.

Furstenau, Marc. "The Ethics of Seeing: Susan Sontag and Visual Culture Studies," Post Script, 26, no. 2 (Winter/Spring 2007): 91-104.

Galloway, Alexander R. Gaming: Essays On Algorithmic Culture. University of Minnesota Press, 2006.

"Garrett Scott and 'Occupation Dreamland' Take Us All To Fallujah."; Buzzflash.com. (January 25, 2006) Available from http://www.buzzflash.com/interviews/06/01/ int06003.html; Accessed March 8, 2008.

Gernsheim, Helmut and Alison. Roger Fenton, Photographer of the Crimean War; His Photographs and his Letters from The Crimea. New York: Arno Press, 1973.

Goggin, Gerard. Cell Phone Culture: Mobile Technology in Everyday Life. New York: Routledge, 2006.

Goodhart, Benjie. "Michael Winterbottom on The Road to Guantanamo,"; Film 4 Available from http://www.channel4.com/film/reviews/feature.jsp?V=3\& SV=5\&id=154599; Accessed March 29, 2008.

Gourevitch, Philip and Errol Morris. "Annals of War: The Woman Behind the Camera at Abu Ghraib," The New Yorker March 24, 2008: 44-57. 
Grajeda, Tony. "The Winning and Losing of Hearts and Minds: Vietnam, Iraq, and the Claims of the War Documentary." Jump Cut (Spring 2007) Available from http://www.ejumpcut.org/currentissue/Grajeda/text.html; Accessed March 8, 2008.

Gunning, Tom. "Heard Over the Phone: The Lonely Villa and the de Lorde tradition of the Terrors of Technology." Screen 32, no. 2 (Summer 1991):184-196.

Haggith, Toby. "D-Day Filming - For Real. A comparison of 'truth' and 'reality' in Saving Private Ryan and combat film by the British Army's Film and Photographic Unit." Film History 14, no. 3/4 (2002): 332-353.

Haraway, Donna. “A Cyborg Manifesto.” In The Cybercultures Reader, ed. David Bell and Barbara M. Kennedy, 291-324. New York: Routledge, 2000.

Helmers, Marguerite and Charles A. Hill, eds. Defining Visual Rhetorics. Mahwah, NJ: Lawrence Erlbaum Associates, 2004.

Howe, Peter. Shooting Under Fire: The World of the War Photographer. New York: Artisan, 2002.

Huppauf, Bernd. "Experiences of Modern Warfare and the Crisis of Representation" In Hollywood and War: The Film Reader, ed. J. David Slocum, 57-67. New York: Routledge, 2006.

Iraq Body Count. Available from http://www.iraqbodycount.org; Accessed April 21, 2008.

Kellner, Douglas. "Bushspeak and the Politics of Lying: Presidential Rhetoric in the "War on Terror"." Presidential Studies Quarterly 37, no. 4 (December 2007): 622-645.

King, Geoff. "Seriously Spectacular: 'Authenticity' and 'Art' in the War Epic." In Hollywood and War: The Film Reader, ed. J. David Slocum, 287-301. New York: Routledge, 2006.

Klingsporn, Geoffrey. "War, Film, History: American Images of 'Real War,' 1890-1920." In Hollywood and War: The Film Reader, ed. J. David Slocum, 33-43. New York: Routledge, 2006.

Koehler, Robert. "In the Valley of Elah (Review).”; Variety (August 30, 2007) Available from http://www.variety.com/index.asp?layout=awardcentral\&jump=review\&rev iewid= VE1117934532; Accessed March 2, 2008.

Kutler, Glenn. "US Military Fatalities in Iraq: A Two-Year Retrospective," Orbis (Summer 2005): 529-544. 
Levy, Andrew. "Saving Private Ryan."; DGA Monthly (January 1999) Available from http://www.dga.org/news/features/saving_private_ryan.php3; Accessed January 27, 2008.

Leys, Ruth. Trauma: A Genealogy. Chicago: University of Chicago Press, 2000.

Loiselle, André. "Double-Telling: Narratives of Traumatic History and Québec's Two 'Terrorist Crises' in the Films of Michel Brault." Paper presented at the Hawaii International Conference on Arts and Humanities. Honolulu. January 2003.

Marchessault, Janine and Susan Lord, eds. Fluid Screens, Expanded Cinema. Toronto: University of Toronto Press, 2007.

Mcnab, Geoffrey. "Iraq in Fragments (Review)," Sight \& Sound 17, no.2 (February 2007): 62.

“Michael Moore vs. Bill O'Reilly Pt. 1 of 2."; YouTube (October 30, 2006) Available from http://www.youtube.com/watch?v=trOdCU6aZOg; Accessed October 15, 2007.

“Michael Moore vs. Bill O’Reilly Pt. 2 of 2.”; YouTube (October 30, 2006) Available from http://www.youtube.com/watch?v=fLHI0b43xa4\&feature=related; Accessed October 15, 2007.

Mirzoeff, Nicholas. Watching Babylon: The War in Iraq and Global Visual Culture. New York: Routledge, 2005.

Moeller, Susan D. Shooting War: Photography and the American Experience of Combat. New York: Basic Books, 1989.

Morris, Errol. "Which Came First, the Chicken or the Egg? (Part One)." The New York Times (September 25, 2007) Available from http://morris.blogs.nytimes.com/ 2007/09/25/which-came-first-the-chicken-or-the-egg-part-one/; Accessed January 26, 2008.

."Which Came First, the Chicken or the Egg? (Part Three)." The New York Times (October 23, 2007) Available from http://morris.blogs.nytimes.com/2007/10/ 23/which-camer-first-the-chicken-or-the-egg-part-three/; Accessed January 26, 2008.

."Which Came First, the Chicken or the Egg? (Part Two)." The New York Times (October 4, 2007) Available fromhttp://morris.blogs.nytimes.com/2007/10/0 4/which-came-first-part-two/; Accessed January 26, 2008. 
Nichols, Bill. Blurred Boundaries: Questions of Meaning in Contemporary Culture. Indianapolis: Indiana University Press, 1994.

Punday, Daniel. Narrative After Deconstruction. New York: SUNY Press, 2003.

Rajagopal, Arvind. "A Nation and its Immigration: The USA After September 11." In Media and Culture Theory, ed. James Curran and David Morely, 75-85, New York: Routledge, 2006.

Reid, Robert H. "US Death Toll in Iraq hits 4000." ABC News (March 23, 2008) Available from http://abcnews.go.com/International/WireStory?id=4503587 \&page=1; Accessed April 21, 2008.

Roberts, Graham. The Man with the Movie Camera: The Film Companion. London: I.B. Tauris, 2000.

Robins, Kevin. Into the Image: Culture and Politics in the Field of Vision. New York: Routledge, 1996.

"Roger Fenton,"; George Eastman House, Still Photograph Archive (2003) Available from http://www.geh.org/fm/fenton/htmlsrc/fenton_idx00001.html; Accessed January 26, 2008.

Rutherford, Paul. Weapons of Mass Persuasion: Marketing the War Against Iraq. Toronto: University of Toronto Press, 2004.

Scifo, B. "The domestication of the camera phone and MMS communications: the experience of young Italians." In A Sense of Place: The Global and the Local in Mobile Communication, ed. K. Nyíri, Vienna: Passagen Verlag, 2005.

Shaviro, Steven. "Southland Tales," The Pinocchio Theory (December 10, 2007) Available from http://www.shaviro.com/Blog/?p=611; Accessed May 13, 2008.

Silverman, Jason. "GIs Shoot Footage for New War Doc."; Wired (April 28, 2006) Available from http://www.wired.com/culture/lifestyle/news/2006/04/70749; Accessed March 7, 2008.

Slocum, J. David. "General Introduction: Seeing Through American War Cinema" In Hollywood and War: The Film Reader, ed. J. David Slocum, 1-21. New York: Routledge, 2006.

. "War as a Way of Seeing." In Hollywood and War: The Film Reader, ed. J. David Slocum, 31-32. New York: Routledge, 2006.

Sobchack, Vivian. "The Scene of the Screen: Envisioning Cinematic and Electronic 
'Presence'" In Materialities of Communication, eds. Hans Ulrich Gumbrecht and K. Ludwig Pfeiffer, 83-106. Stanford: Stanford University Press, 1994.

Sontag, Susan. Regarding the Pain of Others. New York: Farrar, Straus and Giroux, 2003.

Sparshot, F.E. "Vision and Dream in the Cinema." In Philosophy of Film and Motion Picture: An Anthology, eds. Noël Carroll and Jinhee Choi, 82-90. Malden: Blackwell, 2006.

Suvin, Darko. "Estrangement and Cognition." In Speculations on Speculation: Theories of Science Fiction, eds. James E. Gunn and Matthew Canderlaria, 23-36. Lanham, MD: Scarecrow Press, 2004.

Taussig, Michael. Mimesis and Alterity: A Particular History of the Senses. New York: Routledge, 1993.

Taylor, Philip M. "The World Wide Web Goes to War: From Kosovo to the 'War' Against Terrorism." In Web Studies, eds. David Gauntlett and Ross Horsley, 230242. London: Arnold, 2004.

Tumber, Howard and Jerry Palmer. Media at War: The Iraq Crisis. Thousand Oaks: Sage Publications, 2004.

Virilio, Paul. Desert Screen: War at the Speed of Light. New York: Continuum, 2002. Ground Zero. New York: Verso, 2002. The Information Bomb. New York: Verso, 2000. . War and Cinema: The Logistics of Perception. New York: Verso, 1989.

West, Liz. "Reflections on Photography." In The Photography Reader, ed. Liz West, 1218. New York: Routledge, 2003.

Whelan, Robert. Robert Capa: A Biography. Lincoln: University of Nebraska, 1994.

Young, Marilyn, "In the Combat Zone." In Hollywood and War: The Film Reader, ed. J. David Slocum, 315-324, New York: Routledge, 2006.

Zacharek, Stephanie. “'Redacted'." Salon.com (November 16, 2007) Available from http://www.salon.com/ent/movies/review/2007/11/16/redacted/; Accessed April 26, 2008.

Zimmerman, Patricia R. "Public Domains: Engaging Iraq Through Experimental Digitalities." Framework 48, no. 2 (Fall 2007): 66-83. 
Reel Families: A Social History of Amateur Film. Indianapolis: Indiana University Press, 1995.

Zizek, Slavoj. "Passions of the Real, Passions of Semblance," In Hollywood and War: The Film Reader, ed. J. David Slocum, 89-94. New York: Routledge, 2006.

Welcome to the Desert of the Real!: Five Essays on September 11 and Related Dates. New York: Verso, 2002. 